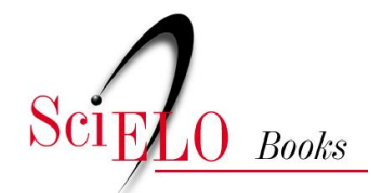

\title{
Universidade e sociedade
}

projetos de extensão da FCLAr-Unesp e suas ações transformadoras

\author{
Cláudio Cesar de Paiva (org.)
}

\section{SciELO Books / SciELO Livros / SciELO Libros}

PAIVA, CC., orgs. Universidade e sociedade: projetos de extensão da FCLAr-Unesp e suas ações transformadoras [online]. São Paulo: Cultura Acadêmica, 2016, 187 p. ISBN 978-85-7983-756-2. Available from: doi: 10.7476/9788579837562. Also available in ePUB from: http://books.scielo.org/id/p7wkm/epub/paiva-9788579837562.epub.

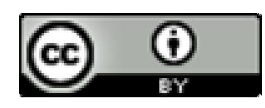

All the contents of this work, except where otherwise noted, is licensed under a Creative Commons Attribution 4.0 International license.

Todo o conteúdo deste trabalho, exceto quando houver ressalva, é publicado sob a licença Creative Commons Atribição 4.0.

Todo el contenido de esta obra, excepto donde se indique lo contrario, está bajo licencia de la licencia $\underline{\text { Creative Commons }}$ Reconocimento 4.0. 


\section{UNIVERSIDADE E SOCIEDADE}




$$
\begin{gathered}
\text { Realização } \\
\text { Pró-reitoria de Extensão Universitária (Proex) } \\
\text { Rua Quirino de Andrade, 215 - 10 andar } \\
01049-010 \text { - São Paulo - SP }
\end{gathered}
$$

Dirigentes da Universidade Estadual Paulista "Júlio de Mesquita Filho" http://www.unesp.br/portal\#!/reitoria_ses/dirigentes-da-unesp/

\section{Conselho Editorial da Pró-reitoria de Extensão Universitária}

Prof. Dr. Cláudio Cesar de Paiva - FCL/Araraquara

Prof. Dr. Eduardo Galhardo - FCL/Assis

Prof. Dr. José Arnaldo Frutuoso Roveda - ICT/Sorocaba

Profa Dra Márcia Pereira da Silva - FCHS/Franca

Profa Dra Maria Cândida Soares Del Masso - FFC/Marília

Profe Dra Rosane Michelli de Castro - FFC/Marília

Prof. Dr. Sebastião Souza Lemes - FCL/Araraquara

Comissão de Avaliação definida pela Pró-reitoria de Extensão Universitária da Unesp

Profa Dra Ana Paula Cordeiro - FFC/Marília

Prof. Dr. Antônio Cézar Leal - FCT/Presidente Prudente

Profa Dra Camila Pires Cremasco Gabriel - FCE/Tupã

Profa Dra Eliana Marques Zanata - FC/Bauru

Prof. Dr. José Carlos Miguel - FFC/Marília

Profa Dra Luciene Cristina Risso - CE/Ourinhos

Profa Dra Maria do Carmo Kobayashi - FC/Bauru

Prof. Dr. Mário Lázaro Camargo - FC/Bauru

Profa Dra Nanci Soares - FCHS/Franca

Profa Dra Rosa Maria Feiteiro Cavalari - IB/Rio Claro

Profa Dra Tânia da Costa Garcia - FCHS/Franca

Profa Dra Tatiana Schneider Vieira de Moraes - FFC/Marília

Prof. Dr. Victor Hugo de Almeida - FCHS/Franca

Membros da Comissão Permanente de Extensão Universitária - CPEU da

Faculdade de Ciências e Letras do Campus de Araraquara

responsáveis pela indicação da obra

Prof. Dr. Cláudio Cesar de Paiva - Presidente

Profa Dra Carla Gandini Giani Martelli

Prof. Dr. Elton Eustaquio Casagrande

Profa Dra Eliza Maria Barbosa

Prof. Dr. Jorge David Barrientos Parra

Profa Dra Luci Regina Muzzeti

Profa Dra Maria Cristina Reckziegel Guedes Evangelista

Prof. Dr. Rafael Alves Orsi

Profa Dra Relma Urel Carbone Carneiro

Profa Dra Roseli Aparecida Parizzi

Rodrigo Tavares

Tatiana Pasetto Corrêa Saraiva 


\section{CLÁUDIO CESAR DE PAIVA (ORG.)}

\section{UNIVERSIDADE E SOCIEDADE}

Projetos de Extensão dA FCLAR-UNESP ESUAS AÇÕES TRANSFORMADORAS 
(C) 2016 Editora Unesp

\section{Cultura Acadêmica}

Praça da Sé, 108

01001-900 - São Paulo - SP

Tel.: $(0 \times x 11)$ 3242-7171

Fax: $(0 x \times 11) 3242-7172$

www.editoraunesp.com.br

www.culturaacademica.com.br

www.livrariaunesp.com.br

feu@editora.unesp.br

CIP - Brasil. Catalogação na Publicação

Sindicato Nacional dos Editores de Livros, RJ

U51

Universidade e sociedade : projetos de extensão da FCLAr-Unesp

e suas ações transformadoras / organização Cláudio César de Paiva.

- 1. ed. - São Paulo : Cultura Acadêmica, 2016.

recurso digital

Formato: ePDF

Requisitos do sistema: Adobe Acrobat Reader

Modo de acesso: World Wide Web

ISBN 978-85-7983-756-2 (recurso eletrônico)

1. Extensão universitária. I. Paiva, Cláudio César de.

$16-33274$

CDD: 378.155

CDU: 378.4 (815.6)

Este livro é publicado pelo Programa de Publicações da Pró-Reitoria de Extensão Universitária da Universidade Estadual Paulista "Júlio de Mesquita Filho" (UNESP)

Editora afiliada:

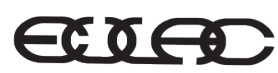

Asociación de Editoriales Universitarias de América Latina y el Caribe

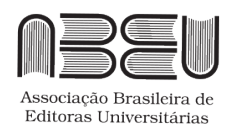




\section{SUMÁRIO}

Apresentação 11

Arnaldo Cortina

1. A extensão como espaço de diálogo sobre ciências e ambiente 17

Maria Cristina de Senzi Zancul

Alessandra Aparecida Viveiro

Flávia Regina Maria

Andréa Midori Machida Ferraz Mendes

Carina Teles de Souza

Fábio Gabriel Nascibem

Juliana Margato Rodrigues

Laís Marin de Campos

Alexandre Harlei Ferrari

Elton de Oliveira Barreto

Laís Goyos Pieroni

Moniele Rocha de Souza

Pedro Neves da Rocha 
Sandra Maria Araújo Dourado

Talita Mazzini Lopes

Viviane Cristina da Silva

Introdução 17

O desenvolvimento dos trabalhos 19

O diagnóstico na FCLAr 20

As ações na FCLAr 24

O diagnóstico na EEBA 27

As ações na EEBA 28

Reflexões e perspectivas 31

Referências bibliográficas 31

2. A reestruturação do habitus no projeto

Ler ÉViver 33

Luci Regina Muzzeti

Cássia Regina Coutinho Sossolote

Darbi Masson Suficier

Maria Fernanda Celli de Oliveira

Greice Kelli Christovam

Projeto Ler É Viver:

relações entre ensino e pesquisa 33

Os objetivos do projeto Ler É Viver 36

Contribuições do projeto Ler É Viver 38

Dificuldades do projeto Ler É Viver 42

A trajetória do projeto Ler É Viver 44

Resultados 47

Referências bibliográficas 49 
3. Formação em serviço de professores da educação infantil para atuação em escolas inclusivas: possibilidades e desafios a partir da extensão universitária 51

Relma Urel Carbone Carneiro

A educação inclusiva na educação infantil:

Programa de Formação em Serviço 59

Considerações finais 65

Referências bibliográficas 68

4. O Programa de Educação de Jovens e Adultos (PEJA) em Araraquara/SP: integrando extensão, pesquisa e ensino 71

Francisco José Carvalho Mazzeu

Introdução 71

A atuação extensionista do PEJA

e a função social da universidade 73

A pesquisa e a produção de

conhecimento no PEJA 77

O ensino e a formação de

professores no âmbito do PEJA 79

Considerações finais 86

Referências bibliográficas 87

5. Apoio e desenvolvimento ao Observatório Cidadão de Piracicaba: extensão, formação e cidadania 89

Carla Gandini Giani Martelli

Wagner de Melo Romão

Introdução 89 
Sobre as conferências 91

De Olho no Legislativo 98

Breves considerações 104

Considerações finais 106

Referências bibliográficas 107

Anexo 108

6. Unesp nos municípios:

apoio ao desenvolvimento econômico dos

municípios da área de influência da FCLAr 111

Cláudio Cesar de Paiva

Suzana Cristina Fernandes de Paiva

Introdução 111

Construindo a proposta de uma

ação extensionista: cenário,

características e objeto 113

Os resultados do projeto 118

Considerações finais 121

Referências bibliográficas 122

7. Heróis para um futuro sustentável 125

Patricia Borba Marchetto

Djalma Roberto Larocca Junior

Ariovaldo de Oliveira Filho

Ana Claudia Fernandes Terence

Jorge Henrique de Oliveira Silva

David Teixeira Pinto

Apresentação 125

Introdução 126

A Cooperativa Acácia 136 
O projeto e os heróis para um futuro sustentável 139

Conclusões 141

Referências bibliográficas 142

8. Ações e reflexões sobre Português como

Língua Estrangeira (PLE) na

Faculdade de Ciências e Letras de Araraquara 145

Nildicéia Aparecida Rocha

Maria Cristina Reckziegel Guedes Evangelista

Rosangela Sanches da Silveira Gileno

Introdução: as primeiras ações...

algumas reflexões 145

O Projeto Ensino de Português como

Língua Estrangeira (PLE) para estrangeiros:

ensino, pesquisa e extensão 151

Os resultados promovidos pelo projeto 156

Desafios e dificuldades encontrados 160

Considerações finais 160

Referências bibliográficas 161

9. Cine Campus: história, memória e ação 163

Fabiane Renata Borsato

Cine Campus 165

O trabalho em grupo: método e ação 165

As contribuições 166

Um pouco da história do Cine Campus e de suas dificuldades 167 
10 CLÁUDIO CESAR DE PAIVA

2011: ano de conquistas 168

2012 e seus percalços 171

2013: momento de mudanças 174

Os integrantes 176

Outros desafios 177

Considerações finais e provisórias 178

Referências bibliográficas 179

Sobre o organizador 181

Sobre os demais autores 183 


\section{Apresentação}

Arnaldo Cortina

A universidade pública brasileira tem por objetivo buscar a excelência no desempenho de três grandes norteadores: o ensino, a pesquisa e a extensão. Longe de serem atividades estanques, essas tarefas possuem uma relação intrínseca. Para que o ensino oferecido pelas universidades públicas brasileiras, na graduação e na pós- graduação, seja inovador, arrojado e de alta qualidade, é impossível dissociar sua prática da pesquisa que o alimenta e que por ele é alimentada. Contrariamente à ideia de que o pesquisador é um sujeito isolado, fechado em si mesmo, voltado para a construção de teorias abstratas ou preocupado em aprimorar as já existentes, os trabalhos de investigação que se desenvolvem na universidade pública devem ter as atividades de ensino como um de seus principais objetivos. No entanto, como a universidade pública deve agir em relação à extensão? Qual é seu papel?

O documento elaborado durante o Fórum de Pró-Reitores de Extensão das Universidades Públicas Brasileiras (Forproex), em 2012, intitulado "Política Nacional de Extensão Universitária", apresenta as metas de uma política que visa tornar a extensão realizada pelas universidades públicas "um instrumento de mudança social em direção à justiça, à solidariedade e à democracia”. Para tanto, reafirma os quinze objetivos que nortearam as discussões sobre o tema durante o Fórum. 
O que se pretende ressaltar neste livro, portanto, é a importância do papel da extensão, responsável pela ligação que a universidade deve estabelecer com a sociedade brasileira em geral, discutindo seus problemas e suas carências, no âmbito das atividades de ensino e de pesquisa. É por meio da extensão que tudo o que se cria e se ensina na universidade influencia e é influenciado pelas demandas sociais. Não é à toa que a epígrafe escolhida para encabeçar o documento produzido pelo Fórum citado anteriormente corresponde a um trecho da obra $A$ universidade do século $X X I$, de Boaventura de Souza Santos. ${ }^{1}$ Segundo o autor, a atividade de extensão deve ser a resposta da universidade ao capitalismo global, cuja finalidade consiste em participar ativamente "na construção da coesão social, no aprofundamento da democracia, na luta contra a exclusão social e a degradação ambiental, na defesa da diversidade cultural".

Assim, com o intuito de divulgar suas ações extensionistas e promover um debate em torno de suas propostas, a Universidade Estadual Paulista "Júlio de Mesquita Filho" (por meio do Edital n.005-2014-Proex) criou o Programa de Publicações Digitais Coleção Extensão Universitária - Selo Cultura Acadêmica. O objetivo dessa publicação consiste na

disseminação digital da produção acadêmica na extensão universitária para a sociedade, desenvolvida pelos docentes e pesquisadores em conjunto com graduandos, pós-graduandos, pós-graduados, servidores técnicos administrativos da Universidade Estadual Paulista e comunidade externa.

É com esse espírito que nasceu esta obra. A Faculdade de Ciências e Letras da Unesp (FCL), câmpus de Araraquara, traz para este volume nove trabalhos de extensão, dentre os vários exis-

1. Santos, Boaventura de Souza. A universidade do século XXI: para uma reforma democrática e emancipatória. São Paulo: Cortez, 2004. 
tentes, desenvolvidos por professores e alunos de diferentes cursos da unidade. Alguns já apontam resultados, uns apresentam suas propostas e outros discutem as perspectivas a partir das quais os projetos se originam. Os capítulos distribuem-se em quatro grandes temáticas.

A primeira enfoca a educação. Em "A extensão como espaço de diálogo sobre ciências e ambiente", discutem-se as questões relativas ao cuidado com o meio ambiente, por meio de ações voltadas para melhoria das condições ambientais na faculdade e na Escola Estadual "Bento de Abreu”. Já "A reestruturação do habitus no projeto Ler É Viver", está vinculado aos trabalhos realizados pelo Centro de Pesquisa da Criança e da Adolescência "Dante Moreira Leite", constituído por professores e alunos do curso de Pedagogia da FCL. Sua proposta consiste em discutir técnicas que motivem os jovens do ensino fundamental a perceber a importância da leitura na mediação com o mundo, com foco especial no gosto pela leitura do texto escrito. O terceiro capítulo, "Formação em serviço de professores da educação infantil para atuação em escolas inclusivas: possibilidades e desafios a partir da extensão universitária”, tem como objetivo discutir a importância da educação inclusiva no ensino fundamental, como forma de garantia ao acesso, à permanência e às condições de aprendizagem a toda a população em idade escolar, independentemente de suas diferenças. Já o quarto capítulo, que também é voltado ao tema educação, "O Programa de Educação de Jovens e Adultos (PEJA) em Araraquara (SP): integrando extensão, pesquisa e ensino", aborda a importante questão da alfabetização da população que não se encontra na considerada fase esperada para a aquisição da competência da leitura e da escrita da língua. Sua proposta volta-se para três importantes ações: a formação do alfabetizador, atuação dos graduandos em sala de alfabetização e parceria com as escolas de educação de jovens e adultos (EJA), da região de Araraquara.

A segunda temática deste livro é "Política e economia". Três são os trabalhos que aqui se apresentam. O Capítulo 5, "Apoio e 
desenvolvimento ao Observatório Cidadão de Piracicaba: extensão, formação e cidadania”, consiste na observação, discussão e avaliação dos trabalhos realizados pelo corpo de vereadores da cidade de Piracicaba, no interior paulista, com vistas a instrumentalizar a sociedade para a melhor compreensão e participação nos processos das políticas públicas. O sexto capítulo, "Unesp nos municípios: apoio ao desenvolvimento econômico dos municípios da área de influência da FCLAr", objetiva construir ações efetivas de diálogo entre a comunidade unespiana, tanto por meio de seus docentes quanto de seus discentes, e os administradores municipais, no sentido de refletir sobre o planejamento de suas administrações e na capacitação dos agentes públicos sociais. O último capítulo que fecha essa temática, "Heróis para um futuro sustentável", tem como proposta examinar as crises ambiental e social desencadeadas pelo atual modelo de desenvolvimento econômico. Dessa forma, examina como se instaura essa crise, as políticas criadas para superá-la, e por fim, analisando a Cooperativa Acácia, responsável pela coleta seletiva de resíduos sólidos na cidade de Araraquara.

Sobre o tema "Comunicação", dois capítulos compõem este volume. "Ações e reflexões sobre Português como Língua Estrangeira (PLE) na Faculdade de Ciências e Letras de Araraquara", demonstra o trabalho construído pela equipe de professores e de estudantes do curso Letras desta faculdade, com o intuito de oferecer cursos de português aos estudantes estrangeiros que vêm para o câmpus de Araraquara como intercambistas.

Por fim, o nono capítulo, intitulado "Cine Campus: história, memória e ação", expõe as ações desenvolvidas pelo projeto Cine Campus, que já faz parte da cultura da própria cidade de Araraquara: há quarenta anos promove a difusão do cinema de arte, muitas vezes com debates a respeito dos filmes apresentados. Desde a reformulação desse antigo projeto, em 2009, sua continuação propõe manter espaços de exibição e de debate de filmes de arte, com o intuito de promover a compreensão das particularidades da linguagem cinematográfica, que envolve recursos expressivos bastante particulares. 
Com isso, pretende-se favorecer a formação cultural e artística do público araraquarense.

Reuniu-se nesta obra, portanto, um pouco do trabalho realizado pelos professores, pesquisadores e alunos da Faculdade de Ciências e Letras da Unesp, câmpus de Araraquara. Aos leitores convido um mergulho nesta amostra do intrincado universo de trabalhos realizados pela universidade pública que transpassam seus próprios muros. 


\title{
1 \\ A EXTENSÃo COMO ESPAÇO DE DIÁLOGO SOBRE CIÊNCIAS E AMBIENTE'
}

\author{
Maria Cristina de Senzi Zancul \\ Alessandra Aparecida Viveiro \\ Flávia Regina Maria \\ Andréa Midori Machida Ferraz Mendes \\ Carina Teles de Souza \\ Fábio Gabriel Nascibem \\ Juliana Margato Rodrigues \\ Laís Marin de Campos \\ Alexandre Harlei Ferrari \\ Elton de Oliveira Barreto \\ Laís Goyos Pieroni \\ Moniele Rocha de Souza \\ Pedro Neves da Rocha \\ Sandra Maria Araújo Dourado \\ Talita Mazzini Lopes \\ Viviane Cristina da Silva
}

\section{Introdução}

O Grupo de Estudos e Pesquisas sobre Formação de Professores e Práticas Pedagógicas em Ensino de Ciências e Educação

1. Versão modificada e ampliada do artigo publicado nos Anais da VI Conferência Internacional de Educação Ambiental e Sustentabilidade "O melhor de ambos os mundos", 2014, p.382-97. 
Ambiental (ECiEA) desenvolveu, durante os anos de 2013 e 2014, dois projetos de extensão articulados: "Ciências e Ambiente: Dialogando com a Comunidade Universitária", no câmpus da Faculdade de Ciências e Letras de Araraquara (FCLAr)/Unesp; e "Ciências e Ambiente: a Universidade em Diálogo com a Escola”, na Escola Estadual Bento de Abreu (EEBA), de Araraquara.

Os projetos tiveram como objetivo estabelecer e cultivar um diálogo com a comunidade dessas duas instituições em relação a aspectos socioambientais e científicos.

O ECiEA reúne alunos de graduação e pós-graduação, pesquisadores e professores da educação básica de diferentes áreas do conhecimento, a exemplo da Biologia, Ciências Sociais, Física, Letras, Matemática, Música, Pedagogia e Química, que procura articular propostas de pesquisa, ensino e extensão voltadas à Educação Ambiental (EA) e ao Ensino de Ciências.

As discussões e investigações realizadas no âmbito do Grupo, bem como as atividades de pesquisa e ensino de cada membro, forneceram subsídios para os dois projetos de extensão, desenvolvidos para proporcionar ações com o objetivo de melhorar as condições socioambientais na FCLAr e na EEBA, incluindo o estímulo à percepção e à integração da comunidade universitária e escolar, respectivamente, nesses ambientes.

Além disso, os projetos fomentavam o interesse por temas ligados a Ciência, Tecnologia, Sociedade e Ambiente (CTSA), favorecendo reflexões sobre questões relacionadas a esses temas que possibilitassem ações para a transformação e melhoria do espaço universitário e escolar.

Como fundamentação teórica, recorremos a autores que se identificam com uma vertente crítica da Educação Ambiental, como Guimarães (2004) e Loureiro (2004), entre outros, bem como o apoio de Paulo Freire $(2005$, 2009). 


\section{O desenvolvimento dos trabalhos}

Os projetos de extensão foram desenvolvidos tomando como referência a metodologia da problematização, estruturada a partir do esquema do arco proposto por Maguerez (Berbel; Gamboa, 2011).

Essa proposta tem início com a observação da realidade, de forma a identificar aspectos importantes e que necessitem ser ampliados, superados, reconstruídos ou transformados em relação à temática explorada.

A etapa da problematização propriamente dita ocorre como um exercício social e político para a construção dos conhecimentos necessários àquela realidade. É possível que surjam vários problemas e, dentre eles, devem ser escolhidos os mais urgentes, que tenham relação mais próxima com as atividades desenvolvidas. A etapa seguinte consiste em identificar quais os pontos-chave do(s) problema(s), o que envolve refletir e levantar os fatores associados a ele(s) e seus determinantes contextuais, dando origem a aspectos que necessitam de respostas e precisam ser investigados, constituindo a base para a teorização. Na etapa da teorização, ocorre a busca sistematizada de conhecimentos científicos e técnicos, de forma a possibilitar a análise do(s) problema(s) por diferentes ângulos e a elaboração de hipóteses de solução. As hipóteses passam por uma análise para que sejam selecionadas aquelas que possam, de forma mais direta, encaminhar soluções (Bordenave; Pereira, 1982).

Seguindo esse movimento, a primeira etapa do trabalho consistiu em elaborar um levantamento nos dois espaços, FCLAr e EEBA, de modo a conhecer a realidade e identificar possíveis problemas. A partir do diagnóstico, o ECiEA deu início a um processo de reflexão crítica sobre os aspectos levantados e de estudo teórico para subsidiar propostas de soluções para os problemas identificados.

As ações realizadas visaram a sensibilização e a difusão de informações, por meio da exibição de filmes e proposição de discussões sobre os temas abordados, realização de palestras e oficinas e montagem de intervenção. 
A seguir apresenta-se uma síntese do levantamento na FCLAr e os resultados encontrados, destacando alguns aspectos que possibilitaram identificar as demandas em relação à temática ambiental; o mesmo acontece em relação à EEBA. As atividades realizadas nos dois espaços emergiram do processo de teorização como hipóteses de solução e contribuíram para a melhoria e superação dos problemas evidenciados.

\section{O diagnóstico na FCLAr}

Na FCLAr, foi desenvolvido um diagnóstico da realidade a partir dos seguintes instrumentos: identificação de projetos existentes na área de Educação Ambiental cadastrados junto à Pró-Reitoria de Extensão da Unesp; consultas à comunidade universitária sobre projetos desenvolvidos ou em desenvolvimento na área ambiental voltados à FCLAr nos últimos cinco anos; consultas sobre gestão de resíduos às secretarias dos dez departamentos ${ }^{2}$ e aos seguintes setores da Faculdade: Divisão Técnica Administrativa, Divisão Técnica Acadêmica, Seção Técnica de Informática, Seção de Atividades Auxiliares, Biblioteca e Restaurante Universitário.

Com relação aos alunos, foi elaborado um questionário, disponibilizado na página eletrônica da instituição, abordando a percepção sobre o ambiente da Faculdade e as formas de interação do estudante com o espaço físico, entre outros aspectos.

Foi identificado, a partir de um catálogo organizado pela Pró-Reitoria de Extensão em 2011, que, naquele ano, realizaram-se dezessete projetos de extensão na Unesp, envolvendo a temática ambiental, voltados à comunidade universitária, com foco em alunos, professores e funcionários das unidades, sendo que alguns ultrapassavam os muros da instituição.

2. Administração Pública; Antropologia, Política e Filosofia; Ciências da Educação; Didática; Economia; Letras Modernas; Linguística; Literatura; Psicologia da Educação; e Sociologia. Disponível em: <http://www.fclar.unesp. br/\#!/departamentos/>. 
De forma geral, as propostas tinham como objetivo integrar o ambiente universitário na vida dos sujeitos, além de sensibilizar e contribuir na formação dos profissionais que saem da Universidade. Naquele momento, não constava nenhum projeto de extensão cadastrado que envolvesse a comunidade da FCLAr em temáticas ambientais.

A consulta à comunidade local (professores, alunos e funcionários) sobre a existência de projetos ambientais, feita via correio eletrônico, teve como retorno somente uma resposta, referindo-se ao Festival de Artes Integradas Gaia, produzido pelo coletivo Colmeia Cultural, que contava com alguns ex-alunos da Universidade. ${ }^{3}$

Assim, percebeu-se que a EA vinha sendo pouco explorada dentro dos espaços da FCLAr.

Já na consulta feita aos departamentos da FCLAr sobre suas iniciativas com relação à gestão de resíduos, identificou-se, em todas as respostas, uma preocupação maior com a redução do uso de papéis e com o descarte de papelões oriundos de caixas. As iniciativas realizadas aproveitavam o papel para rascunho, na produção de blocos, ou reutilização em impressões de menor importância (que não fossem documentos). Todos os papéis de impressão e correspondência a serem descartados, bem como revistas e papelão, eram acondicionados em lugar próprio até que fossem recolhidos por um funcionário de uma empresa privada que possuía contrato com a unidade por meio da Paulista Júnior (empresa da Universidade que visa ao empreendedorismo e à inserção de alunos no mercado de trabalho). Não havia indicação de ações para redução da produção de resíduos.

Já as entrevistas com os funcionários revelaram algumas ações relacionadas à melhoria da gestão de questões ambientais não só desses servidores como também daqueles sob sua responsabili-

3. A primeira edição desse projeto ocorreu em 2009, com o objetivo de difundir o pensamento sustentável por meio de palestras, oficinas e rodas de discussão, apresentações teatrais e shows. O projeto, aberto ao público em geral, é divulgado nas unidades da Unesp de Araraquara, incluindo a FCLAr, e conta com a participação de alunos da unidade como voluntários. 
dade. Entre elas, destacam-se: na Divisão Técnica Acadêmica, a separação de lixo em reciclável e não reciclável; na Divisão Técnica Administrativa, a preocupação com a redução do uso de copos descartáveis e, em ambas, a diminuição no número de impressões.

Na Seção Técnica de Informática, havia redução no uso de papel, pois a maior parte do trabalho era feita no computador. Nessa seção, os copos descartáveis praticamente não eram utilizados, pois todos os funcionários aderiram às canecas. Também havia a separação de material reciclável e, além disso, uma preocupação com o destino de equipamentos de informática obsoletos ou quebrados e sem possibilidade de manutenção.

Na Seção de Atividades Auxiliares (marcenaria, manutenção, jardinagem, limpeza e vigilância) havia uma grande preocupação com as questões ambientais. O funcionário então responsável pela seção, fez um levantamento de espécies da fauna e flora do câmpus e propôs alguns projetos sustentáveis, como a construção de uma cisterna para o reaproveitamento da água de chuva e a implantação de um sistema de iluminação solar.

$\mathrm{Na}$ Biblioteca, os funcionários separavam o lixo compostável do material reciclável e utilizavam canecas ou garrafas para reduzir a quantidade de copos descartáveis. O material bibliográfico que a unidade recebia e que não era condizente com as áreas de pesquisa da FCLAr era enviado para bibliotecas comunitárias ou para os Programas de Educação Tutorial da Faculdade.

Por fim, no restaurante universitário, a maior preocupação entre os funcionários era com a separação de papéis e papelão. Os copos descartáveis eram pouco utilizados; somente visitantes os recebiam. ${ }^{4}$ A quantidade de pessoas que frequentavam o Restaurante Universitário e até mesmo a comida desperdiçada variava muito de acordo com o cardápio, sendo que o pão era o alimento que mais sobrava. Diariamente, em média, eram descartados dois

4. A iniciativa de substituir os copos descartáveis por canecas plásticas foi um projeto da Paulista Júnior, 2008. Segundo a proposta, todo aluno e funcionário que ingressa na unidade recebe uma caneca plástica da Universidade. 
latões de 100 litros por período com restos de comida. Apesar desse desperdício, não parecia haver ações para minimizar o problema. ${ }^{5}$

Em todos os setores, os funcionários disseram reutilizar os papéis na impressão de não documentos e confeccionar blocos de anotações (na gráfica da própria Faculdade). Os papéis descartados e as caixas de papelão eram separados e encaminhados para coleta pela empresa citada anteriormente.

Entre os funcionários, era unânime a percepção da necessidade da criação de um projeto para o descarte correto de resíduos e a separação de materiais recicláveis, bem como a retirada frequente desse material para que não houvesse acúmulo. No entanto, não era geral a compreensão da necessidade de redução da produção desses resíduos, aspecto que parecia já resolvido pelas ações relatadas. A observação do cotidiano da FCLAr por membros do ECiEA evidenciou, entre outros aspectos, uso expressivo de copos descartáveis por professores e funcionários e o descarte incorreto (misturado a restos de alimentos, por exemplo), dificultando o armazenamento e a destinação para reciclagem.

Para análise da perspectiva dos estudantes, foram consideradas respostas de 72 questionários, um número pequeno diante da quantidade de alunos que frequenta o câmpus. As questões sobre a relação do aluno com o espaço da FCLAr revelaram a dificuldade de percepção da faculdade como "meio ambiente", ou seja, uma ausência de sentimento de pertencimento. Assim como os funcionários, os alunos também revelaram uma preocupação com a geração e o descarte de resíduos sólidos.

A partir disso, considerando as concepções de Freire (2005), "resíduos sólidos" foi identificado como um profícuo tema gerador para projetos de EA junto à comunidade da Faculdade.

5. Esse é um dado preocupante e o ECiEA identificou que as ações dos projetos não eram suficientes para enfrentá-lo, pois o desperdício de alimentos envolve outros aspectos, além da educação ambiental. Seria necessária a proposição de um projeto específico, que incluísse também a gestão do restaurante. 


\section{As ações na FCLAr}

Foram realizadas diferentes atividades na FCLAr, entre as quais destacam-se:

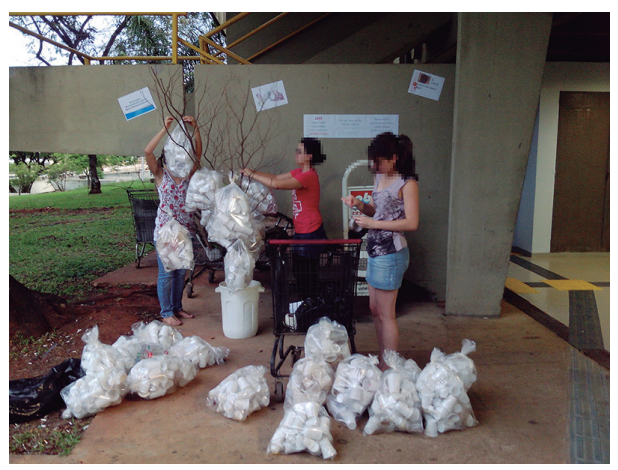

Figura 1.1 - Montagem de instalação com copos descartáveis na FCLAr Fonte: Arquivos ECiEA.

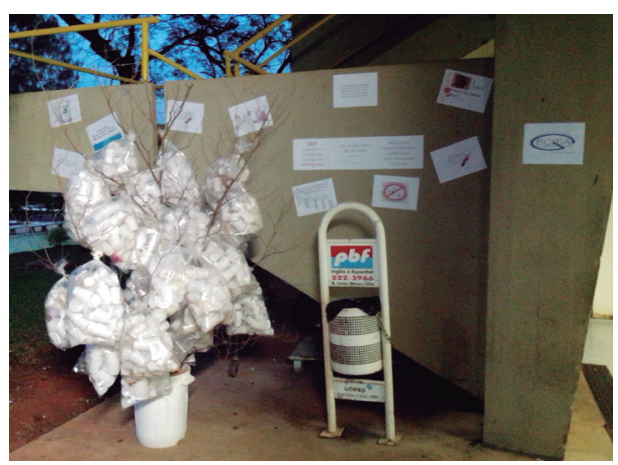

Figura 1.2 - Instalação e campanha sobre uso de copos descartáveis Fonte: Arquivos ECiEA.

- Contagem dos copos descartáveis dispensados durante quatro dias por funcionários e docentes nas copas da FCLAr (1.597 copos) e montagem de uma instalação com o material, exposta durante uma semana. Para acompanhar a instalação, foram con- 
feccionados cartazes, com textos que apresentavam uma estimativa do consumo de copos em um mês e ao longo de um ano, os gastos para reciclagem e o uso da caneca como alternativa, buscando sensibilizar a comunidade sobre a necessidade de redução no uso dos copos (figuras 1.1 e 1.2).

- Exibição do filme Boca de lixo, de Eduardo Coutinho (1992), e discussão sobre a temática resíduos sólidos com a comunidade da FCLAr, tendo como debatedor um engenheiro ambiental, gestor de projetos da Cooperativa de Catadores, Coleta, Triagem e Beneficiamento de Materiais Recicláveis de Araraquara Acácia (Figura 1.3).

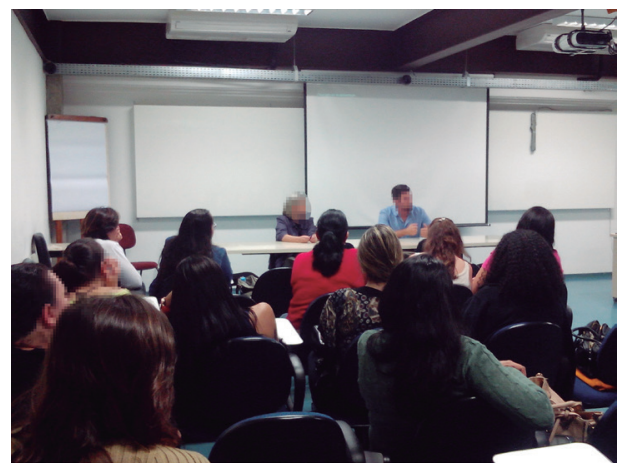

Figura 1.3 - Discussão sobre resíduos sólidos após exibição de filme Fonte: Arquivos ECiEA.

- Exibição do documentário O veneno está na mesa II, de Silvio Tendler (2014), seguida de uma mesa de diálogo, composta por um cientista social e uma bióloga, sobre o modelo de desenvolvimento agrícola empreendido no Brasil, enfatizando aspectos ambientais do uso e ocupação do solo, das condições econômicas e trabalhistas do agricultor, do emprego de agrotóxicos em larga escala, do impacto político e social das ações empreendidas por grandes grupos industriais, latifundiários e governo (figuras 1.4 e 1.5). 


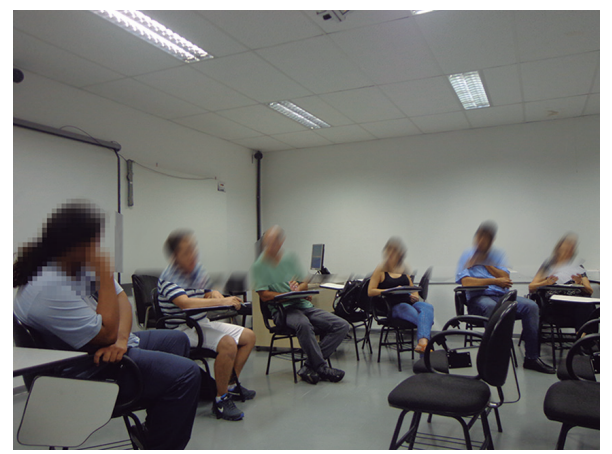

Figura 1.4 - Pesquisadores fazem discussão após a exibição do documentário Fonte: Arquivos ECiEA.

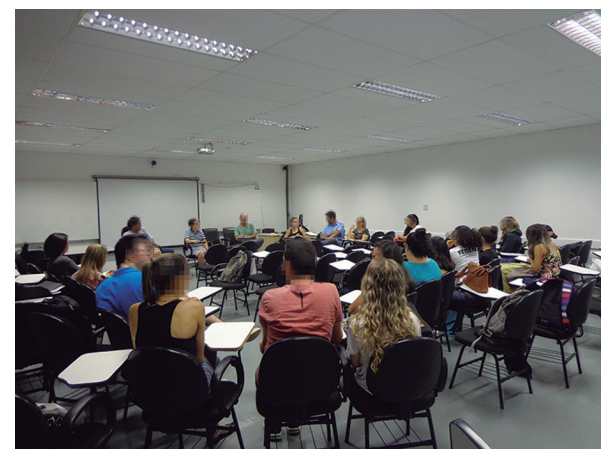

Figura 1.5 - Mesa de diálogo com a comunidade

Fonte: Arquivos ECiEA.

- Roda de conversa sobre problemas ambientais urbanos. Para subsidiar a discussão, o prof. dr. Gustavo Neves da Rocha Filho, professor aposentado da Faculdade de Arquitetura e Urbanismo/ USP, produziu um texto, a pedido do ECiEA, comentando brevemente a questão da poluição urbana, focando a poluição das águas e a produção/tratamento de esgoto urbano. Houve ainda a exibição do documentário Entre paredes de concreto, produzido pela Revista Fapesp (2014), abordando a alteração e a exploração de rios durante o processo de urbanização e expansão da cidade de São Paulo. 


\section{O diagnóstico na EEBA}

Para a elaboração do diagnóstico sobre a realidade observada na EEBA e encaminhamento de propostas de ação, foram aplicados questionários a alunos de turmas de sexto e nono ano do ensino fundamental, escolhidos aleatoriamente, e a professores da escola. No tocante aos alunos, buscou-se conhecer suas percepções sobre o ambiente e o meio ambiente na escola que frequentavam. Além disso, procurou-se identificar o que era importante desenvolver e o que os estudantes já haviam aprendido na escola sobre esse tema.

Aos professores, de diferentes áreas do ensino fundamental e médio, foram feitos os seguintes questionamentos: como eles enxergavam o meio ambiente na escola; se incluíam questões ambientais em suas aulas e, em caso afirmativo, de que forma o faziam; o que poderia ser feito para melhorar o meio ambiente na escola. Como última questão, perguntamos aos dois segmentos o que eles costumavam fazer em prol do meio ambiente. Todas as respostas do questionário de alunos e professores foram classificadas e analisadas para o encaminhamento de ações e atividades desenvolvidas em etapas posteriores.

O diagnóstico na escola incluiu, ainda, a observação (com registro fotográfico) dos pátios antes e após os intervalos e das salas de aula após seu uso. Foi possível identificar grande produção de resíduos e o descarte inadequado da maioria. No caso das salas de aula, era frequente observar folhas de caderno e de papéis de bala espalhados no chão. Em cada sala, existia apenas um recipiente para lixo comum, não havendo local de separação de folhas para reutilização ou reciclagem. Nos corredores, a quantidade de papéis de bala espalhados também era grande e não havia recipientes que pudessem ser usados como lixeiras.

A observação dos pátios evidenciou que os alunos encontravam os locais limpos quando chegavam das salas para o intervalo e, na volta para as salas de aula, o deixavam completamente modificado. Foi possível notar, ainda, um grande acúmulo de resíduos variados, que incluíam papéis de bala, folhas de caderno e restos de ali- 
mentos, jogados displicentemente em diferentes locais, inclusive no pequeno jardim, único espaço verde disponível, e até mesmo dentro das pias e dos bebedouros do pátio.

Diante do panorama observado, consideramos, também no caso da EEBA, que "resíduos sólidos" seria um bom tema gerador para projetos de EA junto aos estudantes.

\section{As ações na EEBA}

Na Escola Estadual Bento de Abreu foram realizadas as seguintes atividades:

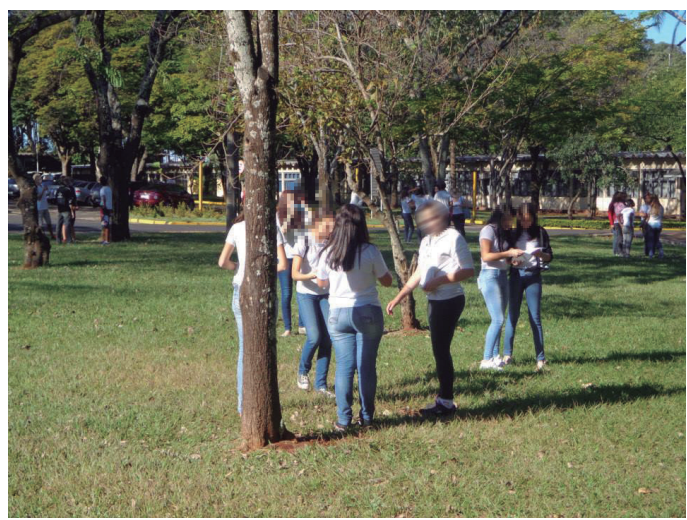

Figura 1.6 - Alunos da EEBA participam de oficina de percepção ambiental

Fonte: Arquivos ECiEA.

- Oficina de percepção ambiental, com alunos do nono ano, na FCLAr. Os estudantes saíram do espaço escolar, vivenciaram outro ambiente, realizando observação da fauna e flora, coleta e análise de solo, identificação da umidade relativa do ar, entre outros aspectos (figuras 1.6 e 1.7). Ao final, foram "provocados" a dar continuidade ao trabalho na escola, percebendo o ambiente em que estão cotidianamente inseridos. 


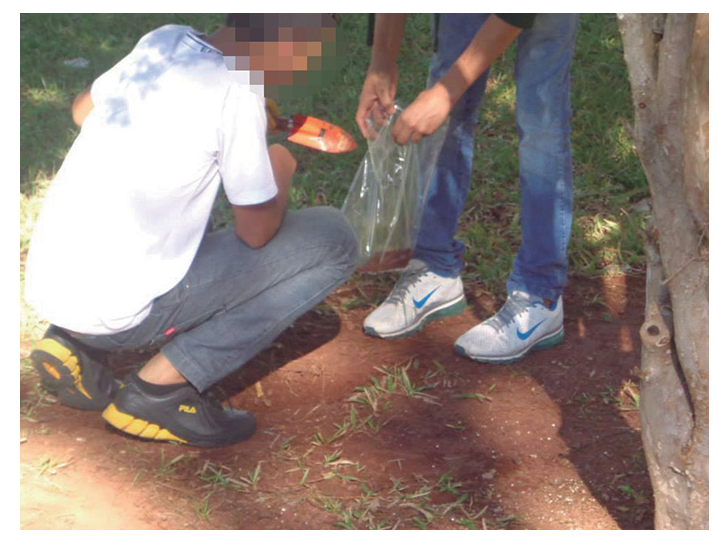

Figura 1.7 - Alunos coletam amostra de solo para análise Fonte: Arquivos ECiEA.

- Palestra sobre arborização urbana e discussão sobre a qualidade do ambiente da escola, incluindo o estímulo à percepção da arborização do espaço, envolvendo alunos do sétimo ano da EEBA. Como parte final da atividade, os alunos realizaram o plantio de árvores nativas em uma área da escola, com a presença do gerente de Reflorestamento da Secretaria Municipal de Araraquara-SP, que também forneceu as mudas (Figura 1.8).

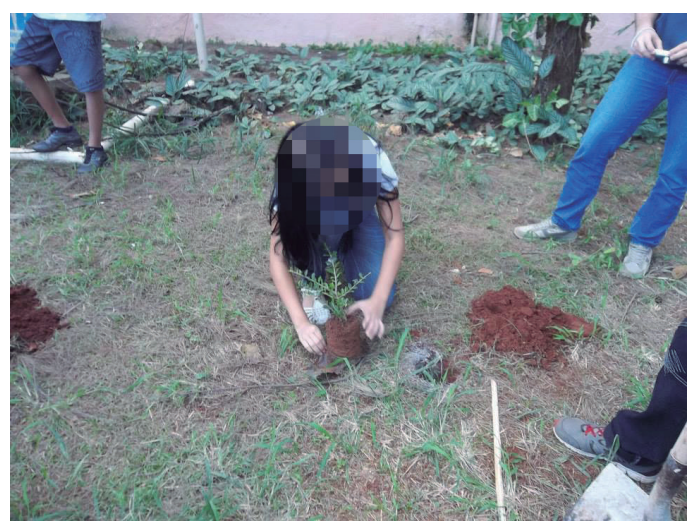

Figura 1.8 - Plantio de mudas nativas na EEBA

Fonte: Arquivos ECiEA. 
- Oficina de ervas e temperos com alunos do oitavo ano, com a constituição de algumas jardineiras que deveriam ser mantidas pelos estudantes para uso no preparo das refeições servidas na escola.

- Exibição do documentário $O$ veneno está na mesa II e palestra sobre alimentação saudável com alunos do ensino fundamental e médio, discutindo as origens dos alimentos ingeridos, os problemas associados a fast-foods e alimentos processados e a necessidade de melhoria de hábitos alimentares.

- Oficina Música e Sensibilização Ambiental com alunos do sexto ano do ensino fundamental, utilizando a paisagem sonora do interior e do entorno da escola para estimular a percepção de diferentes elementos do ambiente (Figura 1.9).

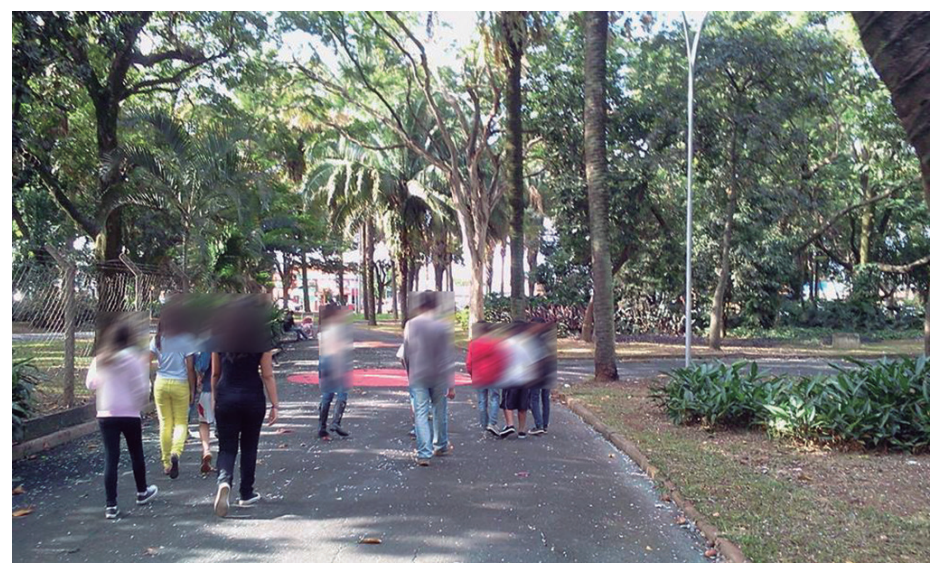

Figura 1.9 - Caminhada em praça próxima à escola para percepção do ambiente

Fonte: Arquivos ECiEA. 


\section{Reflexões e perspectivas}

A partir do cenário diagnosticado foi possível pensar na elaboração de ações envolvendo temas sociocientíficos e ambientais, desenvolvidas tanto na FCLAr quanto na EEBA. As atividades realizadas no âmbito dos dois projetos, a exemplo de algumas aqui descritas, envolveram diferentes públicos e geraram discussões interessantes, subsidiadas por diferentes olhares, englobando as dimensões ambiental, social, histórica e política das questões em foco.

Durante o desenvolvimento dos projetos, buscou-se a construção de outros olhares e novas percepções sobre as questões ambientais e a proposição de alternativas e encaminhamentos para os problemas enfrentados, dentro de uma perspectiva que leva em conta as relações entre ciência, tecnologia, sociedade e ambiente.

Os projetos de extensão também serviram de espaços de diálogo entre os todos os segmentos participantes: professores, estudantes de graduação e de pós-graduação, alunos, professores e gestores da escola pública, na perspectiva freiriana de favorecer o pensar crítico e emancipatório, possibilitando a produção de conhecimento em um processo de transformação das relações na Universidade e entre ela e a sociedade.

\section{Referências bibliográficas}

BERBEL, N. A. N.; GAMBOA, S. A. S. A metodologia da problematização com o arco de Maguerez: uma perspectiva teórica e epistemológica. Filosofia e Educação (on-line), v.3, n.2, p.264-87, 2011.

BORDENAVE, J. D.; PEREIRA, A. M. Estratégias de ensino-aprendizagem. 4.ed. Petrópolis: Vozes, 1982.

BRASIL. Ministério da Educação e do Desporto. Secretaria de Educação Fundamental. Parâmetros curriculares nacionais: meio ambiente: saúde. Brasília: MEC/SEF, 1998.

FREIRE, P. Pedagogia da autonomia: saberes necessários à prática educativa. 39.ed. São Paulo: Paz e Terra, 2009. 
FREIRE, P. Pedagogia do oprimido. 42.ed. Rio de Janeiro: Paz e Terra, 2005.

GUIMARÃES, M. A formação de educadores ambientais. Campinas: Papirus, 2004. (Coleção Papirus Educação.)

LOUREIRO, C. F. B. Trajetória e fundamentos da educação ambiental. São Paulo: Cortez, 2004.

UNIVERSIDADE ESTADUAL PAULISTA "JÚLIO DE MESQUITA FILHO”. Pró-Reitoria de Extensão Universitária. Catálogo dos projetos de extensão da Unesp. São Paulo: Proex, 2011. 


\title{
2 \\ A REESTRUTURAÇÃO DO HABITUS NO PROJETO LER É VIVER
}

\author{
Luci Regina Muzzeti \\ Cássia Regina Coutinho Sossolote \\ Darbi Masson Suficier \\ Maria Fernanda Celli de Oliveira \\ Greice Kelli Christovam
}

\section{Projeto Ler É Viver: relações entre ensino e pesquisa}

Apresentar as relações do projeto Ler É Viver com o ensino e com a pesquisa não é tarefa fácil, pelo fato de ele ter se tornado possível em virtude da participação de profissionais com diferentes formações, com afinidades teóricas que foram se revelando ao longo do tempo. Por esse motivo, durante a apresentação do projeto Ler É Viver, as relações entre ensino e pesquisa não serão identificadas. Desde 2002, perspectivas individuais em relação à questão em pauta passaram a constituir substrato de um projeto coletivo.

Se fosse preciso vincular o projeto Ler É Viver aos eixos temáticos da área de Educação, certamente ele estaria ligado à formação inicial de professores, pelo fato de ser destinado a dois estratos diferentes: a crianças e adolescentes com uma história de fracassos reiterados no interior do sistema escolar e a mediadores de leitura (alunos dos cursos de licenciatura da Faculdade de Ciências e Letras, do câmpus de Araraquara). 
A discussão a respeito do modo como o ensino e como a pesquisa estão na origem do projeto Ler É Viver tornar-se-á mais visível se formularmos a seguinte pergunta: $\mathrm{O}$ que faz que os alunos se tornem mediadores do ato de ler? Seu pertencimento à universidade ou o fato de terem passado por um processo formativo no projeto Ler ÉViver, que lhes deu background para serem assim denominados?

Embora faça parte do senso comum o reconhecimento de que muitos estudantes universitários tiveram uma trajetória escolar que lhes permitiu driblar, de alguma maneira, os processos de exclusão que se materializam em uma sociedade dividida em classes ou que o pertencimento a determinada fração de classe lhes garantiu o acesso à universidade, não se pode afirmar que todos os participantes do projeto tenham familiaridade com a leitura.

Sem dúvida, os alunos se tornam leitores de textos ligados a sua área de formação nas licenciaturas que cursam. Contudo, em sua maioria, os estudantes desconhecem os investimentos que o mercado editorial tem feito na produção de livros que pertencem ao campo da literatura infantil ou infanto-juvenil. Não nos referimos aqui aos clássicos da literatura a que os alunos tiveram acesso no sistema básico de ensino, mas aos livros destinados a diferentes faixas etárias, inclusive a crianças em fase pré-escolar.

Atualmente tem-se acesso a livros destinados a bebês produzidos com diferentes matérias-primas. Há livros de papel; livros que podem ser usados na hora do banho das crianças; aqueles chamados pop-ups, cujas figuras saltam para fora, produzidos com base nas técnicas do kirigami e do origami.

As relações do projeto Ler É Viver com o ensino e com a pesquisa mostram, de um modo ou de outro, que as relações entre universidade e sistema básico de ensino são sempre conflitantes (Sossolote, 2000), apesar de não negarmos o valor dos projetos voltados para a formação continuada do professor. O desejo, no entanto, é de nos afastar de um modelo em que a universidade, como instituição formadora, coloca-se em cursos de formação continuada como se os professores fossem responsáveis pelos problemas relativos à leitura, por exemplo. 
É preciso, ao contrário, questionar o papel que a universidade desempenha na formação primeira dos professores. Por isso, falar de "leitura" com os professores poderá dar margem a conflitos e a confrontos, apesar dos esforços que são feitos para introduzir, nos projetos que envolvem essas duas instituições, o que vem sendo chamado de "leitura de deleite".

De maior alcance são as mudanças que visam a alterar as formas de relação dos graduandos com o livro e com a leitura em sua formação inicial como educador. Essa afirmação é feita com base nos primeiros contatos com os mediadores de leitura que nos mostraram, guardadas as devidas proporções, seu encantamento com os livros. À diferença das crianças, a trajetória dos alunos oriundos do curso de Pedagogia, e, possivelmente, de Letras, mostram que os mediadores de leitura foram submetidos a um processo de aculturamento em relação ao habitus escolar, fato que não garante de per si a familiaridade com o livro.

O projeto Ler É Viver, com base na história de pesquisa e de ensino de seu coordenador e de seus colaboradores, tem como objetivo contribuir para a constituição do habitus de leitura dos alunos mediadores, de forma imperceptível, para em um segundo momento investir em saberes que demonstram a inoperância de se trabalhar com a leitura de forma metódica com uma parcela significativa de alunos excluídos antes mesmo de entrarem na escola, em discussões teóricas sobre questões relativas à estética do texto literário ou ainda investir na aquisição de conhecimentos específicos sobre indivíduos com distúrbios e patologias, fato que pode desequilibrar a relação entre a criança, o livro e a leitura.

Caso a pesquisa fosse realizada por educadores do sistema básico de ensino, seria possível validar a importância desse projeto com base em outros argumentos. Seria possível investigar se professores universitários leem; o que leem; se a leitura constitui para eles uma atividade de entretenimento; qual a relação de familiaridade com os clássicos da literatura brasileira e da literatura mundial. Em síntese, uma das questões que nos colocamos é se os professores universitários, reponsáveis pela formação inicial do professor, são leitores. 


\section{Os objetivos do projeto Ler É Viver}

O projeto Ler É Viver, desde a sua proposição, tem o objetivo de contribuir para a constituição do habitus de leitura de crianças oriundas de frações de classe que têm pouca ou nenhuma familiaridade com bens simbólicos como o livro e a leitura.

O projeto, inicialmente, foi desenvolvido com crianças acolhidas por instituições de caráter assistencialista que tendem a valorizar iniciativas que envolvam as crianças em atividades que tornem a sua permanência na instituição a menos tediosa possível dentre outras expectativas que podem ser deduzidas do relato que faremos.

Os objetivos do projeto Ler É Viver, no entanto, sempre estiveram na contramão dos objetivos das instituições de acolhimento à criança. Não se trata de suprir necessidades materiais ou intelectuais por meio de ações que excluam uma vez mais as crianças de processos inclusivos pelos quais os adultos são comumente responsáveis em virtude de seu pertencimento a uma rede de relações que os tornam capazes, em muitos casos, de minimizar a miséria material na qual essas crianças vivem.

O projeto Ler É Viver parte de pressupostos vinculados a outra concepção a respeito das crianças cujas famílias foram excluídas do sistema formal de trabalho ou que pertencem a extratos sociais que inviabilizam o acesso do sujeito aos bens materiais e simbólicos.

A exclusão do sistema produtivo que compromete a aquisição de capital econômico e de capital cultural pelos sujeitos não foi interpretada pelos adeptos da teoria de Pierre Bourdieu, teórico que influencia esse projeto, como se os indivíduos passassem, a partir dessa falta, a apresentar "déficits cognitivos" que interferem negativamente na leitura daqueles que não tiveram acesso a ela no interior da família.

No entanto, o leitor pode ser levado a pensar que no projeto Ler É Viver nega-se a cultura de frações de classe que estão à margem do sistema produtivo. Trata-se de reconhecer somente que a família é a primeira instância estruturante de todas as formas de comportamento, de disposições do sujeito e de que é possível rees- 
truturar habitus primeiros por meio de mediações (re)estruturantes projetadas a partir da intencionalidade dos sujeitos, no caso do projeto Ler É Viver, do coordenador, de colaboradores e de mediadores do ato de ler.

Embora se tenha conhecimento de que o termo cultura deve ser colocado no plural, a fim de não reproduzirmos em nossos trabalhos a visão da classe dominante, Pierre Bourdieu, cuja obra constitui para nós o referencial teórico-metodológico por excelência, foi um sociólogo da educação que se preocupou em explicar por que o sistema escolar pode excluir os seus agentes, sobretudo quando a cultura apreendida no interior de suas famílias não coincide com aquela que a escola vem legitimando ao longo de sua história ou que vem sendo legitimada ao longo da história da humanidade.

Bourdieu, em sua obra, nos oferece elementos para compreender os processos históricos, caracterizados por relações de poder, que determinam o fracasso escolar de uma parcela significativa dos agentes escolares.

O sociólogo explica (2002, p.55) a esse respeito:

A cultura da elite é tão próxima da cultura escolar que as crianças originárias de um meio pequeno burguês (ou, a fortiori, camponês e operários) não podem adquirir, senão penosamente, o que é herdado pelos filhos das classes cultivadas: o estilo, o bom gosto, o talento, em síntese, essas atitudes e aptidões que só parecem naturais e naturalmente exigíveis dos membros da classe cultivada, porque constituem a "cultura" (no sentido empregado pelos etnólogos) dessa classe. Não recebendo de suas famílias nada que lhes possa servir em sua atividade escolar, a não ser uma espécie de boa vontade cultural vazia, os filhos das classes médias são forçados a tudo esperar e a tudo receber da escola, e sujeitos, ainda por cima, a ser repreendidos pela escola por suas condutas por demais "escolares".

A consciência teórica de que existe uma fração de classe que detém, nas palavras de Bourdieu, os códigos legitimados pela es- 
cola, responsáveis, por sua vez, pela trajetória de êxito e de sucesso de agentes que se encontram no interior do sistema escolar que inclui para excluir está na origem do projeto Ler É Viver. Ao trabalhar com a leitura, temos como objetivo torná-la uma atividade familiar a frações de classe privadas de direitos assegurados no texto da "lei" aos cidadãos brasileiros.

É preciso dizer que, embora no início do projeto houvesse uma valorização da leitura de livros que pertencem ao campo discursivo da literatura infantil, pouco a pouco novos objetos foram incorporados ao projeto.

\section{Contribuições do projeto Ler É Viver}

A contribuição do projeto Ler É Viver para a constituição de habitus que deveriam ter sido cultivados no interior das famílias cujos filhos têm uma trajetória de fracasso escolar, sem dúvida, está relacionada ao método do qual se parte para envolver as crianças que dele participam em práticas culturais e discursivas legitimadas pelo sistema escolar.

Apesar de saber que muitas áreas do conhecimento tomam a leitura como objeto de investigação e de compreensão, ela constitui, no interior do sistema escolar, um dos componentes do currículo da disciplina Língua Portuguesa.

Todavia, quando se destina parte das aulas de Língua Portuguesa à leitura de textos, o que sobressai é a apresentação aos alunos de protocolos elaborados para aferir-se o grau de compreensão do texto proposto para a interpretação.

Se ler é atribuir sentidos, como bem disse Orlandi na apresentação de seu livro intitulado Discurso e leitura (1988), os alunos atribuem sentido aos textos lidos tanto em situações em que são "convidados" a dizer o que entenderam, tendo de localizar no texto excertos que demonstrem o acerto da interpretação, como em situações em que ler constitui um ato solitário. Em situações como essa, os alunos constroem e atribuem sentidos ao texto sem que a 
sua leitura tenha de ser validada por intérpretes reconhecidos pelo sistema escolar.

Certamente, pode-se assumir posturas diferentes em relação aos instrumentos dos quais a escola se serve para aferir o grau de entendimento dos textos pelos alunos. Pode-se tanto legitimar tais práticas (afinal, cabe à escola "ensinar" a ler), como assumir atitudes contrárias que levaria a colocar em xeque os protocolos construídos, demonstrando que eles resultam de excessiva obsessão da parte do professor, fato que gera, por sua vez, sentimentos persecutórios nos leitores submetidos a avaliações. É possível afirmar ainda que a escola está mais preocupada em avaliar a eficácia da leitura de seus agentes, valorizando a aprendizagem em detrimento do ensino propriamente dito, embora acredite-se que é possível ensinar-se a ler. Pode-se ainda envidar esforços no sentido de verificar o alcance e os limites dos métodos utilizados. Se trilhássemos esses caminhos, o projeto que estamos desenvolvendo seria outro.

Para nós, trata-se de apresentar no espaço deste capítulo, a lógica subjacente às práticas propostas no projeto Ler É Viver com o objetivo de criar condições para que crianças com uma história de exclusão possam ter uma trajetória escolar qualitativamente diferente.

E a primeira questão que se colocou - coerente com o referencial teórico de Pierre Bourdieu - consistiu em saber por que as crianças consideradas carentes, se levarmos em conta os conhecimentos, as habilidades e as competências exigidas pela escola, fracassam.

Pierre Bourdieu demonstra, de inúmeras maneiras, a importância da família na aquisição da cultura legitimada pela escola. Segundo Muzzeti (2013, p.22),

A aquisição da cultura legitimada pela escola fora da escola exige que a família possua disposições, inclinações para consumir os bens culturais considerados legítimos e que, consequentemente, incite os seus descendentes a essas práticas, representadas, segundo Bourdieu, principalmente pela leitura, frequência em rodas de contação de histórias etc... 
O que se aprende com Pierre Bourdieu e seus colaboradores, independentemente, ou não, de a família estruturar saberes, conhecimentos, disposições, informações em relação à cultura legitimada pela escola, é que a família estrutura o capital cultural próprio a sua fração de classe. E o faz de forma não consciente, não sistemática, não metódica.

No projeto Ler É Viver, esse modo de apreensão do saber foi replicado por partir-se do princípio de que esse é o modus operandi para a criança adquirir o gosto e o prazer pela leitura. Trata-se, assim, de cultivar hábitos como a família o faz: de forma imperceptível. O projeto Ler É Viver encontra-se, neste sentido, na contramão dos sistemas formais de ensino.

Outra importante contribuição está relacionada ao fato de que, no processo de atribuição de sentidos ao texto, o leitor investe os signos engendrados em seu interior de significados relacionados à sua experiência de vida, à sua relação com a cultura. A relação texto e leitor é mediada tanto pela cultura de sua fração de classe como por suas experiências individuais.

Esse fato dá margem a experiências múltiplas, à construção de analogias entre os sentidos materializados no texto e os sentidos reconhecidos pelo leitor, ainda que não se tenha acesso à leitura das crianças e dos adolescentes que passaram a participar do projeto, pois a leitura é uma atividade invisível à percepção e à avaliação.

$\mathrm{Na}$ escola, todavia, a polissemia, a possibilidade de atribuir-se sentidos diferentes ao texto, está fora de questão, uma vez que o que funciona em sala de aula é o jogo imaginário que leva o aluno a atribuir os sentidos que ele imagina que o professor atribuirá ao texto lido - possivelmente porque o professor constitui o leitor exclusivo do texto do aluno (Orlandi, 1988).

Por isso, considera-se que as atividades de conto e reconto de histórias podem produzir estrangulamentos na leitura tal qual vem sendo realizada pelos alunos, pois o professor perde o estatuto que lhe foi dado historicamente de leitor único do texto do aluno.

Outro fato que merece ser destacado está relacionado a princípios da teoria bourdieuniana, segundo os quais os objetos são cul- 
turalmente construídos. Quem já não ouviu um adulto dizer a crianças de tenra idade: "Seu livro está de ponta-cabeça".

Em relação ao livro, pode parecer ingênuo colocar as seguintes questões:

- Lê-se o livro de cima para baixo ou de baixo para cima?

- Da esquerda para a direita ou da direita para a esquerda?

- Da primeira à última página ou da última à primeira?

- A leitura deve ser contínua ou podemos saltar algumas páginas?

- Podemos ler somente os signos não verbais, as ilustrações, ou não?

O trabalho do projeto Ler É Viver demonstrou que essas indagações são pertinentes, como já nos mostrou a história da escrita e da leitura, pois presenciam-se situações em que o livro, em virtude de suas dimensões, foi usado como prancha por crianças. Outros usos podem ser feitos desse objeto da cultura.

Além disso, esses fatos mostram que, em uma sociedade dividida em classes ou em frações de classes, certamente os professores vivem paradoxos que os mutilam. Ao mesmo tempo que são levados a teorizar sobre a função social da leitura em cursos de formação inicial e/ou continuada - questão legítima para ensinar-se a ler -, há alunos que podem fazer uso do livro, um dos suportes do texto escrito, com outras funções, fato que suscita a expressão de juízos de valor. Um enunciado possível seria aquele bastante desgastado segundo o qual estaríamos vivendo situações de barbárie. Afinal, pode-se usar dar uma livrada na cabeça de outrem, utilizando o livro com outras funções

O pressuposto do qual partimos neste projeto é o de que o ensino formal da leitura não é capaz de estabelecer relação de familiaridade entre a criança e o livro, se ela não tiver sido construída fora da escola, em espaços não monitorados e não influenciados por avaliações internas e externas ao sistema escolar. 
Passemos agora aos desafios, às dificuldades com as quais nos deparamos.

\section{Dificuldades do projeto Ler É Viver}

Muitas dificuldades foram enfrentadas ao longo do tempo. Elas serão enumeradas sem a expressão de juízos de valor a respeito de qual seria a maior ou menor delas. Como os participantes do projeto têm formações diferentes, é de se esperar que as dificuldades não tenham sido as mesmas.

Desde o início do projeto Ler É Viver, a sua coordenadora reiterava os princípios que deveriam orientar os encontros com as crianças envolvidas no projeto. As práticas de leitura não deveriam ser metódicas e sistemáticas, de forma a garantir que a familiaridade da criança com o livro se desse de forma imperceptível.

A pergunta que atormentava profissionais que não leram a obra de Pierre Bourdieu em sua totalidade, já que fizeram leituras esparsas de seus textos, esbarrava sempre no significado que deveria ser atribuído a atividades não metódicas e não sistemáticas, certamente porque aproximavam atividades não metódicas à ausência de método. Por isso, duas questões devem ser discutidas.

A primeira diz respeito ao próprio modo como o projeto foi questionado por um dos colaboradores. Observe-se que as palavras utilizadas para questionar a proposta do projeto Ler É Viver derivavam do campo discursivo daqueles que trabalham com métodos escolares. Lentamente, foi possível compreender que práticas de leituras não metódicas e não sistemáticas derivam de um método de aproximação do texto, de modo a familiarizar a criança com a leitura.

Outra questão colocada e que constituiu uma extensão do relato que acaba de ser feito diz respeito à formação dos mediadores de leitura: a concepção de método que orienta as práticas de leitura das crianças que participam do projeto Ler É Viver é a mesma da 
qual se parte no trabalho formativo dos mediadores de leitura? A resposta é sim e não, como foi explicado anteriormente.

Quando se parte do princípio de que as crianças que não tiveram acesso ao capital cultural legitimado pela escola tinham o direito, por exemplo, de conhecer textos elaborados segundo os cânones da literatura, não se estava querendo dizer que o mediador de leitura deveria desconhecer as propriedades estéticas do texto literário. Distinguir, no entanto, as demandas formativas de diferentes agentes nem sempre foi tarefa simples. As respostas vieram de um projeto em construção.

Outro obstáculo enfrentado está relacionado à produção de conhecimento na área das ciências humanas. O trabalho de extensão que está sendo apresentado colocou em cena relações polêmicas com o que se considera a função da universidade. Parecia não haver lugar na academia para projetos como o Ler ÉViver que colocava em cena questões relativas à (des)articulação existente entre teoria e prática, responsável pela naturalização da divisão de trabalho no interior da universidade, levando muitos a expressarem juízos de valor, segundo os quais o projeto que insistíamos em propor poderia ser realizado por professores sem titulação acadêmica.

Se a reposição de capital cultural só é possível por experiências pessoais intransferíveis e in loco, vivenciamos situações de desconforto quando o projeto Ler É Viver passou a ocorrer no anfiteatro da universidade ou em momentos em que as crianças foram convidadas a conhecer a Faculdade de Ciências e Letras, do câmpus de Araraquara. Os olhares e a indiferença dos "catedráticos" colocavam os colaboradores na condição de professores de "jardim da infância", fato que mostra ainda estarmos longe de conviver com a diversidade. A pobreza se materializa de inúmeras formas. Não fosse o caso, não seria possível reconhecer a fração de classe da qual as crianças eram oriundas.

A terceira dificuldade incontornável, tendo em vista o método bourdieuniano, está relacionada à existência de uma cultura presente tanto no sistema básico de ensino como na universidade que 
exige a comprovação, a mensuração de resultados. Assim ao trabalhar com a leitura, parece ser sempre necessário demonstrar que as crianças que participavam do projeto passaram a ler. O coordenador, colaboradores e mediadores de leitura teriam de comprovar o nível de rendimento das crianças antes e depois do projeto Ler É Viver.

Diante dos pressupostos que orientam o trabalho dos mediadores de leitura, temos de conviver com o invisível, com mudanças que só podem ser aferidas depois de muito tempo transcorrido e que certamente só professores e pais atestarão, pois os objetivos do projeto não estão ligados à alfabetização entendida em sentido estrito, mas a mudanças qualitativas de disposições das crianças e adolescentes do projeto em relação ao ato de ler.

\section{A trajetória do projeto Ler É Viver}

O projeto Ler É Viver teve início em 2002 e desde 2004 constitui um projeto de extensão cadastrado junto à Pró-Reitoria de Extensão, da Universidade Estadual Paulista "Júlio de Mesquita Filho". Anualmente, o projeto vem recebendo verbas para consumo de materiais indicados pelo coordenador a partir de esforços empreendidos pelos colaboradores e mediadores de leitura para a definição de materiais que possam contribuir para o desenvolvimento intelectual dos participantes do projeto.

Inicialmente, o projeto Ler É Viver foi desenvolvido em duas instituições cujas crianças não se encontravam em fase escolar. Eram crianças consideradas carentes, aceitas pela instituição, pois as mães trabalhavam o dia todo.

Naquele momento, o projeto era desenvolvido nas próprias instituições periodicamente. Com o passar do tempo, no entanto, os encontros passaram a acontecer em nossa Faculdade. Pareceu-nos o lugar ideal para que o projeto fosse desenvolvido, porque é um lócus do saber legítimo. Também se perguntava quantas daquelas crianças poderiam algum dia sonhar ou mesmo ter contato 
com essa instituição. Segundo o referencial de Bourdieu (2002), o conhecimento, ou melhor, o contato com uma instituição dessa natureza constitui experiência diferencial para a herança cultural das crianças que participaram ou que participam do projeto.

A seguir serão apresentados outros aspectos que concorreram para que o projeto ocorresse no câmpus de Araraquara.

Dados os objetivos do projeto, que pretendia que as crianças se apropriassem do livro de forma não metódica, não formal, espontânea, considerou-se que o seu desenvolvimento estava sendo comprometido pelos fatos que ocorriam nas instituições nas quais as crianças eram acolhidas. Como em todas as instituições, há a figura dos agentes disciplinares, responsáveis pelo bom comportamento das crianças. A regra básica, portanto, era que se comportassem diante das visitas. Se havia ou não sanções em virtude de mau comportamento, não viemos a saber.

A segunda questão estava relacionada às manifestações dos próprios agentes das instituições em relação ao projeto Ler É Viver. De forma consciente ou não, com intencionalidade ou não, a falta de interesse inicial das crianças pelo livro ou o pouco tempo que se dedicavam a folheá-lo, constituía para eles um trunfo do qual podiam dispor para comprovar que não era a falta de esforços da equipe que comprometia o desenvolvimento das crianças. A questão da índole das crianças estava posta nas avaliações que faziam.

A terceira questão a destacar está relacionada ao zelo, ao asseio das crianças, que eram duplamente excluídas: pela família e pela instituição que as acolhia. A própria arquitetura denotava a situação de "acolhimento" das crianças.

Assim, a Faculdade de Ciências e Letras nos pareceu o lugar ideal para que o projeto fosse desenvolvido. Algumas crianças, no entanto, já estavam familiarizadas com a Faculdade, pois, desde o início do projeto, as projeções de filmes de Walt Disney recriados a partir dos contos de fada ocorriam na FCL. Em muitas sessões, a participação das mães foi fundamental.

Em relação aos bens simbólicos, o livro sempre foi privilegiado. Como o objetivo do projeto consistia em oferecer às crianças textos 
com valor estético, inicialmente realizamos levantamentos bibliográficos para tomar conhecimento da faixa etária para a qual os livros eram destinados. Para a idade de 0 a 6 anos, alguns autores se destacaram: Tatiana Belink; Eva Furnari; Sonia Junqueira; Ana Maria Machado; Sylvia Orthof; José Paulo Paes; Ziraldo; Ruth Rocha etc.

Os encontros eram sempre realizados com músicas escolhidas a dedo, como Mozart para crianças, Villa Lobos para crianças, Ravel etc. As canções da coleção Palavra Cantada embalaram o encerramento de algumas sessões ocorridas no Câmpus.

Outros materiais foram comprados visando à expressão das crianças: papel; lápis; borracha; canetas hidrocor; giz de cera; dedoches; fantoches; jogos aparentemente não pedagógicos cujo potencial para aprendizagem foram reconhecidos pouco a pouco.

A terceira instituição na qual desenvolvemos o projeto foi o Lar Escola Redenção. No entanto, as suas condições de funcionamento são bastante diferenciadas quando comparadas às outras instituições onde o projeto Ler É Viver foi desenvolvido. Instituição voltada para o atendimento de meninos em período contrário àquele no qual estudam, ela visa a reposição de capital cultural que a escola não consegue realizar por meio do oferecimento de oficinas.

Mesmo diante de uma instituição que parece estar próxima dos objetivos do sistema escolar, buscou-se espaço para o projeto Ler É Viver, desenvolvido com base nos princípios bourdieunianos. É interessante destacar que, nesse caso específico, os adolescentes do sexo masculino puderam selecionar as leituras que queriam fazer: os mangás.

Para esses alunos foram adquiridos ainda livros de Clarice Lispector; Fanny Abramovich; Pedro Bandeira; Pedro Bloc; Lygia Bojunga; Maria Clara Machado; Monteiro Lobato etc.

Nesse momento, o projeto está vinculado ao Centro de Pesquisas da Criança e da Adolescência "Dante Moreira Leite" que conta com uma equipe de especialistas que realizam importante trabalho à comunidade de Araraquara. Sendo assim, os adolescentes com problemas de aprendizagem do Lar Escola Redenção come- 
çaram a ser atendidos por equipe multidisciplinar formada por psicólogas, fonoaudióloga e psicopedagoga.

Por último, é preciso destacar o próprio desenvolvimento do projeto, que não abstrai as condições materiais de existência das crianças e dos adolescentes. Há depoimentos de agentes da instituição e da família que comprovam os avanços feitos, o que demonstra o seu potencial para a aprendizagem.

\section{Resultados}

O projeto Ler É Viver, por meio de pressupostos que se assentam em categorias bourdieunianas como habitus, capital econômico, capital cultural, capital escolar, vem conseguindo reestruturar formas de comportamento e de disposições que distinguem frações de classe cujo capital cultural está próximo ou coincide com o capital cultural de escolas que reproduzem a hierarquia social por meio da distinção dos saberes necessários para a manutenção do status quo ou de relações de pertencimento e de exclusão em relação ao sistema econômico e social.

No campo das ciências humanas, reconhece-se que a atenção, a memória, o raciocínio, a imaginação, o pensamento e a linguagem constituem processos estruturantes, indispensáveis para a atividade cognoscível. As teorias distinguem-se evidentemente em virtude do peso atribuído a esses processos considerados imprescindíveis para a cognição.

De modo bastante caricatural, uma vez que essas estruturas de conhecimento não constituíram objeto deste texto, outro embate responsável pelos dissensos entre os teóricos que se preocupam com a aquisição do conhecimento está relacionado à natureza dos processos já referidos. Sua aquisição é determinada biologicamente ou por meio de relações sócio-históricas que estão inseridos em processos de contínuas mudanças?

É preciso dizer que, embora tenhamos colocado as dissidências de forma polarizada, os setores da pesquisa ligados à Biologia e 
à História proliferam, no momento atual, quando se trata de explicar a natureza das "aptidões" que, para Pierre Bourdieu, constituem estruturas estruturantes condicionadas por relações entre frações de classe, determinantes, por sua vez, pela apropriação de conhecimentos.

Teórico que atribui às relações historicamente construídas valor preponderante na apropriação dos processos responsáveis pela cognição, Pierre Bourdieu defende a tese de que o desenvolvimento primeiro da atenção, da memória, do raciocínio, da imaginação, do pensamento e da linguagem é cultivado no interior da família.

O projeto Ler É Viver foi desenvolvido em consonância com essa tese, na medida em que seus participantes reconhecem com Pierre Bourdieu que esse desenvolvimento constitui pré-requisito para a aquisição de capital escolar em situações em que o capital econômico e o capital cultural da família não contribuem na aquisição dos processos já referidos.

A seguir, como conclusão, serão relatados breves depoimentos das famílias dos participantes do projeto. Observe o leitor que as avaliações revelam que as perguntas foram formuladas para saber sobre o aproveitamento das crianças no projeto. Os responsáveis assim se posicionaram.

[... agora ele está lendo, escrevendo, está aprendendo as coisas na escola. Está ajudando bastante. (Pai de aluno)

[Está havendo] mais entendimento na hora da leitura e o gosto por estar lendo uma história, um conto de fábulas. Então eles prestam um pouco mais atenção e [dão] palpites e se interessaram também pelo teatro que vai ter. Então acho que tudo isso é válido. (Professora de instituição atendida pelo Projeto)

As mais tímidas ficam um pouco mais soltas, se soltam mais. (Cuidadora de instituição atendida pelo Projeto) 
Estou adorando o projeto porque ele já mudou bastante. Ele já está lendo tudo, porque antes não lia nada. Agora até a professora já notou a capacidade de estar lendo. (Mãe de aluno)

Sim, percebi. A professora da B. falou que ela está desenvolvendo muito e a G. também. (Mãe de alunas)

Percebi. Ele está mais ativo, está mais esperto. A professora falou que ele está mudando bastante. (Mãe de aluno)

Mudaram bastante o comportamento na participação, leitura, nas brincadeiras. (Coordenadora de instituição atendida pelo Projeto)

\section{Referências bibliográficas}

BOURDIEU, P. A escola conservadora: as desigualdades frente à escola e à cultura. In: NOGUEIRA, M. A.; CATANI, A. (Orgs.). Escritos da educação. Petrópolis: Vozes, 2002. p.229-37.

MUZZETI, L. R. Relatório trienal referente ao periodo compreendido entre 2010 a 2012. Araraquara: Faculdade de Ciências e Letras da Unesp, 2013.

ORLANDI, E. P. Discurso e leitura. São Paulo: Cortez, 1988.

SOSSOLOTE, C. R. C. O discurso de vulgarização da Linguística no aparelho escolar. Araraquara: FCL/Laboratório Editorial/Unesp; São Paulo: Cultura Acadêmica, 2000. 


\section{3}

\section{FORMAÇÃO EM SERVIÇO}

\section{DE PROFESSORES DA EDUCAÇÃO}

INFANTIL PARA ATUAÇÃO

\section{EM ESCOLAS INCLUSIVAS:}

\section{POSSIBILIDADES E DESAFIOS A PARTIR DA EXTENSÃO UNIVERSITÁRIA}

A educação brasileira tem discutido de forma mais efetiva, há não mais de duas décadas, um novo paradigma em que a escola, segmento social fundamental na formação humana, deverá oferecer a todos os indivíduos condições plenas de desenvolvimento.

Esse paradigma recebe o adjetivo de novo porque, historicamente, a escola não se constituiu como espaço aberto de educação para toda a população brasileira. O movimento da inclusão escolar é relativamente novo se considerarmos o grande período de exclusão escolar que muitas minorias historicamente marginalizadas viveram, sendo impedidas de usufruir das oportunidades educacionais disponibilizadas aos que tinham acesso à educação. A educação inclusiva pressupõe uma reorganização no sistema educacional de forma a garantir acesso, permanência e condições de aprendizagem a toda a população em idade escolar. Embora o "todos" seja abrangente e englobe uma variedade de segmentos, nesta reflexão vamos nos ater a um segmento populacional específico: alunos com deficiência que, por características distintas, muitas vezes requerem da escola ações diferenciadas. 
A história da educação de pessoas com deficiência apresenta um quadro de total exclusão. Essas pessoas eram institucionalizadas e viviam longe do convívio social geral, passando por períodos em que eram separadas em escolas ou classes especiais estabelecidas de acordo com as características de suas deficiências, entendendo que sua participação em ambientes comuns só seria possível mediante um processo de normalização, até o momento atual que prevê direitos educacionais iguais e equidade educacional.

O entendimento da proposta de educação inclusiva requer uma análise do modelo anterior com vistas a delimitar o papel da escola no processo de desenvolvimento e aprendizagem do aluno com deficiência. A escola e a classe especial destinadas à educação do deficiente tinham como meta a normalização do sujeito de forma que o mesmo pudesse se assemelhar o máximo possível com os sujeitos normais, para então poder ser integrado ao convívio comum, nesse caso, a escola.

Esse objetivo, além de negar a condição de diferença e estabelecer parâmetros homogêneos de desenvolvimento, como se isso fosse possível, descaracterizou o papel da escola como instituição responsável pela formação das novas gerações a partir do conhecimento adquirido, e passou a ter como foco principal, e na maioria das vezes, único, a modificação do aluno com deficiência através da reabilitação de funções ou da habilitação para o desempenho de funções inexistentes em virtude da deficiência.

Com essa atuação, a escola contribuiu para o não desenvolvimento acadêmico dos alunos com deficiência, ficando os mesmos alijados dos processos de educação formal e, como era de se esperar, sem atingir a normalização. A diferença é uma condição inerente à humanidade e a aceitação desse valor é um imperativo inquestionável. Morin (2011, p.49-50) apresenta de forma belíssima esse princípio:

Cabe à educação do futuro cuidar para que a ideia de unidade da espécie humana não apague a ideia de diversidade, e que a da sua diversidade não apague a da unidade. Há uma unidade humana. Há uma diversidade humana. A unidade não está apenas 
nos traços biológicos da espécie Homo sapiens. A diversidade não está apenas nos traços psicológicos, culturais, sociais do ser humano. Existe também diversidade propriamente biológica no seio da unidade humana; não apenas existe unidade cerebral, mas mental, psíquica, afetiva, intelectual; além disso, as mais diversas culturas e sociedades têm princípios geradores ou organizacionais comuns. É a unidade humana que traz em si os princípios de suas múltiplas diversidades. Compreender o humano é compreender sua unidade na diversidade, sua diversidade na unidade. É preciso conceber a unidade do múltiplo, a multiplicidade do uno.

Diante desse panorama, a concepção de educação inclusiva tem se fortalecido. A escola precisa se abrir para a diversidade, acolhê-la, respeitá-la e, acima de tudo, valorizá-la como elemento fundamental na constituição de uma sociedade democrática e justa. Essa concepção pressupõe que a escola busque caminhos para se reorganizar de forma a atender todos os alunos, inclusive os com deficiência, cumprindo seu papel social.

Conforme Tardif e Lessard (2013, p.102), a escola tem como objetivo formar milhões de alunos de acordo com padrões, para que possam cumprir um papel na sociedade mais tarde. No entanto, os alunos apresentam um vasto leque de diferenças. Para os autores, se a escola quer produzir um resultado uniforme, ela precisa ser capaz de reconhecer as diferenças, rotinizar a variabilidade de seus serviços, deve trabalhar com as diferenças individuais por meios gerais; além do que, a socialização das crianças e dos adolescentes para os papéis adultos é massiva e complexa. A escola trabalha com alunos durante longos períodos e deve oferecer serviços educativos em etapas coerentes, considerando diferenças progressivas e exigindo tarefas de socialização diferenciadas.

Espera-se da escola inclusiva competência para desenvolver processos de ensino e aprendizagem capazes de oferecer aos alunos com deficiência condições de desenvolvimento acadêmico dentro de suas possibilidades, que os coloque de forma equânime em condições de acessarem oportunidades no mercado de trabalho e na vida. 
Considerando a inclusão como uma concepção diferente de entendimento da vida em sociedade, a tarefa escolar fica um pouco mais complexa. Em uma concepção de escola inclusiva, o que está em jogo não é a matrícula de alunos com ou sem deficiência, mas sim a abertura da escola para oferecer educação a todos os alunos. Essa escola ainda não faz parte da nossa realidade porque, historicamente, a escola não foi criada nem desenvolvida para atender a todos, portanto, não sabemos fazer "inclusão", pois, como concepção, implica mudança de valores e atitudes.

Sabemos, no entanto, que essa mudança implica necessariamente garantia de acesso, permanência e desenvolvimento de todos os indivíduos na escola. Esse "todos" engloba a diversidade existente na sociedade sem distinção de nenhuma natureza, conforme os termos da lei. Por isso, uma escola inclusiva não é uma escola que matricula alunos com deficiência, mas uma escola em que alunos com quaisquer características, sejam elas físicas, raciais, étnicas, religiosas, sociais, econômicas, psicológicas, mentais etc., além de garantia de acesso, permanência e desenvolvimento, tenham suas diferenças valorizadas como meio de promoção de uma sociedade equânime. Discorrendo sobre a individualidade do trabalho docente, Tardif e Lessard (2013, p.257) afirmam:

Ora, essa dimensão individual significa que o objeto do trabalho docente é portador de indeterminações, pois cada indivíduo é diferente e parcialmente definido por suas diferenças, às quais é preciso, de certo modo, respeitar e não querer modificá-las. Embora ensinem a coletividades, os professores não podem agir de outro modo senão levar em conta as diferenças individuais, pois são os indivíduos que aprendem e não a coletividade.

A transformação necessária na escola passa, entre outros fatores - políticos, sociais, econômicos -, pela mudança de concepção dos atores educacionais: gestão, professores, comunidade. Diante da necessidade de atendimento a esse novo paradigma que pressupõe o oferecimento de oportunidades iguais de ensino e aprendizagem 
para uma clientela diferenciada de alunos, o papel do professor ganha uma dimensão diferente. Embora o professor não seja o único responsável pelas mudanças necessárias, sua função ganha destaque - na escola, ele é o responsável direto pelo processo de ensino/ aprendizagem dos alunos. Dessa forma, a discussão sobre formação de professores, tanto inicial como em serviço, é um imperativo.

Pensar o trabalho docente implica pensar sua formação e valorização. Qualquer mudança educacional exige, entre outros aspectos, reflexão. $\mathrm{O}$ professor, elemento fundamental nesse processo, não pode se abster de tal tarefa. As mudanças estruturais (embora decorrentes de ações políticas e econômicas, e portanto condicionadas a interesses externos à escola), uma vez alcançadas, tendem a permanecer como conquistas do processo de transformação social e educacional que estamos vivendo.

No entanto, as mudanças de concepções capazes de transformar atitudes culturalmente arraigadas de desvalorização e preconceitos em relação ao diferente em atitudes de entendimento e valorização da diferença como elemento natural da constituição humana (e, portanto, fundamental para o desenvolvimento da sociedade) são mudanças processuais que só serão alcançadas a partir da reflexão sobre a prática em uma escola aberta e acolhedora, em que a presença do diferente é elemento constituinte da mesma.

Ao pensar em um aluno com características diferentes na escola é preciso organizar a ação educativa de forma que suas especificidades sejam atendidas. Essa organização não pode ser responsabilidade só do professor, que sozinho tem de buscar respostas satisfatórias, muitas vezes sem elementos para essa busca. Nesse contexto, a retomada dos aspectos reflexivos do trabalho docente se faz necessária.

Conforme Sacristán (1995, p.77),

no desenvolvimento profissional, há que realizar ações em âmbitos diferentes. Ações e programas de formação têm de incidir, nos contextos em que a prática se configura, em que se produzem determinações para as iniciativas dos professores. 
Nessa perspectiva, concordamos com Giovanni (1998, p.46) quando afirma:

a formação profissional não pode mais se reduzir aos espaços formais e escolarizados, organizados com esse fim. Ela precisa ser concebida como algo que pode se dar antes, durante e depois do processo formal, como "espaços de reflexão sobre o próprio trabalho". Ou seja, precisa ser concebida como processo de desenvolvimento que se inicia no momento da escolha da profissão, percorre os cursos de formação inicial e se prolonga por todos os momentos de exercício profissional ao longo da carreira, incluindo as oportunidades de novos cursos, projetos e programas de formação continuada.

Rodrigues e Rodrigues (2011) colocam os fatores essenciais para o desenvolvimento da educação inclusiva: quem serão os agentes da mudança e como essa mudança é gerida e planejada? Embora reconheça a importância da ação e participação das decisões políticas, da comunidade, da família, dos próprios alunos, enfim, de todos ligados à escola, os autores realçam o trabalho e o papel do professor, que não é um funcionário no sentido de alguém que segue instruções precisas e estritas, nem um técnico que resolve problemas através de metodologias, mas alguém que lida com a gestão de um currículo, o que implica uma multiplicidade de opções e caminhos a seguir dando-lhe uma autonomia com uma consequência muito importante. Se puder optar, o professor só adotará as mudanças que acredita serem justas e úteis para o seu trabalho. Ele pode fechar a porta de sua sala de aula e deixar a reforma para fora ou pode fechar a porta para pôr em prática reformas não oficializadas.

Autores como Tardif (2012) defendem, a partir de pesquisas realizadas com professores, que os saberes docentes são construídos em grande medida no exercício prático da profissão e na possibilidade de interação com pares na troca coletiva. Nóvoa (1995) comenta que, contrariamente a outras organizações, a escola dedica 
muito pouca atenção ao trabalho de pensar o trabalho, isto é, às tarefas de concepção, análise, inovação, controle e adaptação. Moita (2000) pondera que ninguém se forma no vazio: formar-se supõe troca, experiência, interações sociais, aprendizagens, um sem-fim de relações. Ter acesso ao modo como cada um fabrica essas relações é ter em conta a singularidade da sua história e, sobretudo, o modo singular como age, reage e interage com os seus contextos. A construção de uma escola inclusiva pressupõe a reorganização de seus tempos e espaços de modo a garantir ao professor condições efetivas de reflexão sobre sua ação, a partir de sua prática.

A ação pedagógica na educação infantil ainda é cercada de concepções advindas do início dessa escolarização, em que a instituição tinha um caráter assistencialista e sua função era cuidar da criança para a mãe trabalhar. O planejamento das ações pedagógicas para as crianças de faixas etárias menores é muitas vezes negligenciado no trabalho docente. A função educativa do ensino infantil é um aspecto a ser refletido pelos atores e autores educacionais no sentido de superar a visão da escola assistencialista e promover uma concepção de escola como segmento de formação das novas gerações.

A presença de alunos com necessidades variadas solicita, muitas vezes, adaptações na ação docente que precisam ser construídas. Conforme Moita (2000, p.137): "As experiências profissionais não são formadoras de per si. É o modo como as pessoas as assumem que as tornam potencialmente formadoras". Não existe uma pedagogia ou uma didática específica e pronta para tais alunos, o que existe é uma condição diferente que precisa ser vivenciada em todas as suas esferas, com condições de tempo, espaço e interlocução para refletir em todos os condicionantes o que essa situação apresenta. Como já discutido anteriormente, a escola só se tornará efetivamente inclusiva na medida em que reorganizar seu trabalho, a partir de sua realidade, considerando o que é necessário para que todos os alunos aprendam. Essa "nova” postura pede formação.

A ação reflexiva com o caráter de transformação não acontece espontaneamente, é necessário que haja uma formação capaz de 
alertar o sujeito para essa prática. Conforme Perrenoud (2002), a formação para uma prática reflexiva abrange pesquisa e exercícios para análise de casos reais e um procedimento clínico global. A formação teórica é válida, mas não suficiente. O sujeito precisa relacionar teoria e prática e prática e teoria e conseguir transpor a teoria para a atuação na realidade e a partir da realidade produzir teoria.

Considerando a proposta de educação inclusiva uma opção nacional referendada nas políticas educacionais brasileira, entende-se que o movimento de reorganização da escola deve começar na educação infantil. Ela é a primeira etapa da educação básica e é um movimento capaz de proporcionar às novas gerações experiências de convívio com a diferença que superem o modelo social excludente e construam um modelo social inclusivo. Conforme Rodrigues e Rodrigues (2011, p.106):

É certo que os grandes promotores da Educação Inclusiva da atualidade nunca experimentaram a inclusão na sua vida escolar. Chegaram à premência da Educação Inclusiva através do seu próprio convencimento quanto à ética e à justiça da Inclusão. Não deixa de ser estimulante pensar que impulso poderá sofrer a Educação Inclusiva quando esta deixar de ser desenvolvida por pessoas para quem ela não é uma mera opção ética mas, sim, o resultado de uma experiência pessoal e vivida.

O estabelecimento da educação infantil como um direito de todas as crianças no Brasil só foi reconhecido com a Constituição Federal de 1988 e com a aprovação da Lei de Diretrizes e Bases da Educação Nacional (LDB), de 1996, que define a educação infantil como primeira etapa da educação básica que tem como finalidade o desenvolvimento integral da criança até 6 anos em seus aspectos físico, psicológico, intelectual e social.

Drago (2011, p.36-7) salienta que muitas pesquisas evidenciam e denunciam o papel educacional menor que ainda é direcionado à educação infantil, considerado irrelevante e substituível por paliativos assistencialistas, como se fosse melhor que a criança pe- 
quena ficasse em casa com a mãe. Essas pesquisas enfatizam que a educação infantil precisa possuir um caráter educativo que vença barreiras históricas de discriminação e preconceito em relação à infância, às escolas infantis e aos professores destas. Para o autor, educação infantil significa um novo modo de se pensar a educação, ou seja, uma nova proposta de trabalho para cidadãos de direitos, que precisam de uma educação de qualidade, já que possuem papel essencial na sociedade.

\section{A educação inclusiva na educação infantil: Programa de Formação em Serviço}

Descobertas científicas colocam em pauta a necessidade de estruturação da educação infantil para o atendimento de alunos com necessidades educacionais especiais, proporcionando aos mesmos oportunidades de desenvolvimento pleno de seu potencial. Conforme a Política Nacional de Educação Especial na Perspectiva da Educação Inclusiva (Brasil, 2007), a inclusão escolar deve ter início na educação infantil, quando se desenvolvem as bases necessárias para a construção do conhecimento e seu desenvolvimento global.

Por sua trajetória histórica de não atendimento do aluno com deficiência, a escola comum não está preparada para tal tarefa, ou seja, nossa escola não é inclusiva e não sabe ser, o que significa que sua transformação no sentido de cumprimento legal e de responder positivamente aos anseios sociais requer alterações em toda a sua dinâmica. Essas alterações envolvem vários aspectos: estruturais, econômicos, instrumentais, de recursos humanos, pedagógicos etc. Entendemos que a formação de professores da educação infantil visando a uma prática pedagógica inclusiva é o início do processo de construção desse novo modelo.

A partir desse entendimento foi proposto o desenvolvimento de um projeto de extensão. Ele teve como objetivo geral fazer uma investigação sobre a formação de professores articulada a um trabalho na rede de ensino municipal de Araraquara, para uma formação 
em serviço aos professores da educação infantil que promovesse a educação inclusiva.

Para a realização desse objetivo, foi desenvolvido, paralelamente, um estudo sobre formação de professores e um programa de formação em serviço em uma escola de educação infantil.

A denominação Programa de Formação em Serviço foi dada por ser uma proposta abrangente de formação desenvolvida não somente com aspectos teóricos como em um curso, mas com estudos de casos reais das professoras, criação de espaço de reflexão por parte das mesmas de seu trabalho, de suas práticas pedagógicas, de suas concepções sobre o papel da escola e de todos os elementos envolvidos nessa atuação. A complementação "em serviço" sugere a formação concomitante ao exercício da profissão, sendo esse exercício objeto da própria formação. Os objetivos específicos para a realização do programa foram:

- mapear a rede de ensino infantil do município de Araraquara para a obtenção de dados sobre os alunos, público-alvo da educação especial nela existente;

- levantar as necessidades de formação em serviço com vistas à efetivação de um trabalho inclusivo por meio de um questionário investigativo; e

- elaborar e implementar uma proposta de formação em serviço em uma escola da rede.

O mapeamento da rede de ensino, primeiro objetivo específico do programa, se deu mediante a análise de planilhas fornecidas pela Secretaria Municipal de Educação, em que constavam os dados dos alunos atendidos pela educação especial. ${ }^{1} \mathrm{O}$ levantamento demonstrou que a educação infantil do referido município tinha 38 escolas com alunos da educação especial, totalizando 82 alunos matricu-

1. A saber, alunos com deficiência (intelectual, auditiva, visual, física e múltiplas), alunos com altas habilidades/superdotação e alunos com transtornos globais do desenvolvimento. 
lados, sendo 57 do sexo masculino e 25 do sexo feminino, na faixa etária de 2 a 5 anos com os seguintes diagnósticos: transtorno invasivo do desenvolvimento, hidrocefalia, baixa visão, síndrome de Down, deficiência intelectual, deficiência física, paralisia cerebral, síndrome do 4X, síndrome do pterígio múltiplo, deficiência auditiva, deficiência visual, autismo, deficiência múltipla (intelectual e física), alteração cromossômica 139, síndrome do 1ํarco, deficiência múltipla (intelectual e auditiva) e surdez.

A escolha da escola participante da pesquisa se deu mediante reunião com a gerente de educação especial que apontou uma escola com vários alunos com deficiência matriculados, onde os professores cumpriam o horário de trabalho pedagógico coletivo (HTPG), espaço que viabilizaria a execução do programa. ${ }^{2}$

O próximo passo foi a apresentação do projeto de pesquisa à diretora da escola escolhida, que também apoiou e valorizou a ideia. A diretora foi convidada a participar do programa bem como instruída a estender o convite a todos os membros de sua equipe. Isso propiciou um encontro com as professoras no HTPC. Embora todos tenham sido convidados, somente as professoras cumpridoras do HTPC realmente participaram.

Durante parte do desenvolvimento do programa de formação na escola houve a colaboração de alunos do curso de Pedagogia da FCLAr que atuaram como bolsistas do projeto de extensão. A participação dos alunos tinha o objetivo de contribuir em sua formação possibilitando um contato direto com a prática pedagógica e com a perspectiva de uma formação reflexiva.

Outro objetivo foi levantar com as próprias professoras suas necessidades de formação considerando as demandas de uma escola inclusiva. Para tanto, foi aplicado um questionário investigativo. A análise da tabulação dos dados mostrou claramente a necessidade

2. Muitos professores da rede têm contratos em que esse horário não é previsto em sua carga horária de trabalho, sendo sua permanência na escola unicamente nos horários de atendimento aos alunos em sala de aula, característica que inviabilizaria a proposta do projeto. 
de mudanças, tanto estruturais como na prática pedagógica, para a efetivação do que se entende por educação inclusiva.

Essa análise mostrou que as professoras não receberam nenhuma informação prévia sobre as características dos alunos, suas especificidades, necessidade de adaptações, entre outros. Em concepções sobre a inclusão de alunos com deficiência no ensino comum apareceram respostas como: tenho dúvidas se é o lugar para ele estar, depende de infraestrutura física, profissional capacitado, currículo adaptado, necessidade de atendimento educacional especializado, entre outras. Sobre temas de interesse para discussão no programa de formação, os principais foram: breve síntese das deficiências, adaptação curricular, avaliação, contato com as famílias, aspectos legais sobre inclusão, postura do educador, trabalho com a cobrança do sistema em termos de resultados (aprendizagem de conteúdos), sugestão de atividades. Quando perguntado sobre a interação da criança deficiente com as outras, as professoras foram unânimes em responder que a interação é normal, tranquila, que percebem que a turma acolhe o deficiente de forma natural.

O programa de formação aconteceu quinzenalmente no horário de trabalho pedagógico coletivo e contou com a participação média de cinco professoras. O programa teve uma duração de três anos, alternando discussões teóricas, estudo de caso de alunos e reflexão sobre a prática pedagógica com indicação de mudanças.

Esse programa apresentava uma dupla característica: construir conhecimentos sobre processos de reflexão coletivos desencadeados a partir da análise da prática pedagógica e, ao mesmo tempo, intervir no contexto em que essas práticas ocorriam, possibilitando construção e reconstrução colaborativa de conhecimentos entre todos os participantes (professoras, coordenadora do projeto e bolsistas). As experiências de discussão e reflexão vivenciadas foram dinâmicas formadoras importantes porque permitiram que as participantes reconhecessem pontos fundamentais de sua atuação pedagógica, entre outros: 
- algumas mudanças necessárias deveriam ser disparadas por elas;

- necessidade do conhecimento das especificidades de seus alunos;

- entendimento do papel da escola no desenvolvimento da criança pequena;

- necessidade de parcerias para a efetivação de um ensino inclusivo;

- importância de tempos e espaços definidos para trocas coletivas e reflexões individuais.

Os dados mostram as dificuldades da ação reflexiva por parte das professoras - elas não vivenciam tal prática em outras situações de formação, o que é referendado pela literatura -, porém, mostram uma avaliação positiva referente à criação de um espaço de interlocução entre a prática pedagógica, o estudo teórico e a prática reflexiva, pois contribuiu com a formação em serviço das professoras participantes e modificou práticas pedagógicas, garantindo um ensino de qualidade para todos.

A formação em serviço do professor deve buscar uma mudança de sua prática com todos os alunos, de um trabalho homogeneizador para um trabalho pedagógico com recursos instrumentais e metodológicos necessários para o desenvolvimento e aprendizagem compatíveis com as características individuais de cada aluno. $\mathrm{O}$ professor deve planejar o trabalho pedagógico de forma a garantir a cada aluno aquilo que lhe é peculiar e que lhe dará acesso ao currículo desenvolvido para a classe toda. As novas demandas da educação inclusiva sugerem que a escola deve buscar novos caminhos para efetivar uma prática inovadora capaz de responder satisfatoriamente a todos os alunos. A imposição legal da educação inclusiva não vai por si só mudar o que realmente acontece, como em um passe de mágica. Essa realidade requer, entre outros aspectos, mudanças no processo de formação de professores, para que os objetivos da escola inclusiva sejam alcançados. A travessia do modelo de escola excludente para o modelo de educação inclusiva requer, 
entre outros aspectos, políticas de formação de professores capazes de responder às atuais demandas educacionais.

O programa desenvolvido nesses três anos, que tinha como um de seus objetivos criar um espaço de reflexão capaz de produzir mudanças a fim de transformar uma prática homogeneizadora e excludente em uma prática heterogênea e inclusiva, demonstrou que a organização do nosso sistema de ensino não possibilita a concretização de ações similares de forma sistemática, ainda que tenha sido relevante, na medida em que demonstrou que esse espaço contribuiu de forma efetiva para algumas mudanças pontuais. Em cada um dos três anos, o grupo de professoras sofreu grandes alterações, o que inviabilizou a continuidade do trabalho. ${ }^{3}$ Muitas reflexões desencadeadas pelo programa careciam de aprofundamento, inclusive teórico, para resultarem em mudanças de práticas. Essas mudanças dependem de tempos e espaços definidos e constantes. Conforme Nóvoa (2013, p.206-7),

Para conseguir uma transformação de fundo na organização da profissão docente é fundamental construir novos modelos de formação. O diálogo profissional tem regras e procedimentos que devem ser adquiridos e exercitados nas escolas de formação e nos primeiros anos do exercício docente. Sem isso, continuaremos a repetir intenções que dificilmente terão uma tradução concreta na vida dos professores e das escolas. Nada será conseguido se não se alterarem as condições existentes nas escolas e as políticas públicas em relação aos professores. É inútil apelar à reflexão se não houver uma organização das escolas que a facilite. É inútil rei-

3. O professor, na maioria das vezes, não cria um vínculo permanente com a escola em que atua, pois a escolha da escola em que vai atuar a cada ano depende de uma pontuação adquirida por dias trabalhados. Esse sistema propicia uma "dança" em que a rotatividade na busca de escolas que melhor atendam as necessidades pessoais de cada professor impede a criação de vínculos permanentes, de projetos coletivos de escola, de uma cultura escolar construída a partir de referências sólidas. 
vindicar uma formação mútua, interpares, colaborativa, se a definição das carreiras docentes não for coerente com este propósito. É inútil propor uma qualificação baseada na investigação e parcerias entre escolas e instituições universitárias, se os normativos legais persistirem em dificultar essa aproximação.

Outro aspecto a ser considerado é o tempo designado pelo sistema educacional para que o professor reflita sobre sua prática de forma sistemática. Várias participantes manifestaram na avaliação do programa que consideravam insatisfatório o tempo designado aos encontros (eles eram quinzenais). Embora no último ano todas as professoras permanecessem uma hora por dia na escola para a realização do HTPC, esse tempo não era utilizado para atividades que propiciassem a discussão e a reflexão pedagógicas. Esta é uma cultura que precisa ser criada no ambiente escolar. Embora o programa desenvolvido tenha se proposto a tal tarefa, sem uma sistematização dessa prática como um projeto de gestão educacional, tal ação se perde.

\section{Considerações finais}

Buscou-se neste texto tecer algumas ponderações sobre as mudanças necessárias na estrutura social e escolar brasileira na direção de um ideal de respeito e valorização de todos. Analisamos alguns dos muitos aspectos envolvidos nessa temática. Esses aspectos estão diretamente relacionados e envolvem uma reflexão abrangente que não se esgota nos limites deste projeto de extensão. Pensar uma escola sem exclusão, capaz de responder às necessidades educacionais diferentes de seus alunos, desconstruindo assim uma cultura social de desvalorização de grupos marginalizados, requer o enfrentamento de barreiras políticas, sociais, culturais. Mudanças são necessárias no entendimento do papel da etapa de escolarização em um modelo social de escola muitas vezes de tempo 
integral, em que muitos alunos passam em média oito horas por dia na escola e têm, portanto, grande parte de seu desenvolvimento e aprendizagem acontecendo ali.

Para alunos com necessidades educacionais diferenciadas advindas de deficiências a mudança na escola passa necessariamente pela atuação do professor. Dessa forma, inclusão escolar, educação infantil, formação de professores são elementos-chave do processo de mudança. Essa mudança só ocorrerá se os atores sociais envolvidos se tornarem autores da história, deixando de simplesmente representar um papel estabelecido e esperado. No espaço escolar, isso significa que os professores, não só têm de querer a mudança independente das conjunturas estabelecidas. Uma sociedade inclusiva não se constrói por decreto: é preciso desejá-la e construí-la. Essa construção requer políticas e práticas capazes de abrir novos caminhos. A valorização do papel da educação infantil e a instrumentalização de professores para uma atuação revolucionária fazem parte das mudanças necessárias.

Embora ainda timidamente, ações práticas têm sido desenvolvidas em nosso sistema educacional no sentido de criar possibilidades de participação de todos. Uma sociedade realmente inclusiva é um imperativo que ainda temos que atingir. A escola é um dos segmentos sociais imprescindíveis nessa conquista. $\mathrm{Na}$ escola formamos, nos formamos e transformamos, na escola copiamos e criamos, na escola mantemos e mudamos, na escola vivemos. Estamos no momento de criar alternativas novas de atuação dentro da escola a partir das demandas existentes. Não é possível mudar a escola primeiro, para fazê-la inclusiva depois. A escola se fará inclusiva no processo de mudança.

Em um dos momentos do programa, foi feito o estudo de caso de um aluno com paralisia cerebral, usuário de cadeira de rodas, com dificuldades especificamente motoras. $\mathrm{O}$ aluno era acompanhado por uma agente educacional que tinha o papel de auxiliar o aluno em sua locomoção, higiene, alimentação etc., porém sem funções pedagógicas. Durante a descrição da participação do aluno, a professora relatou uma série de dificuldades do mesmo, bem como 
sua impossibilidade de atender a tais especificidades. O grupo então propôs uma série de adaptações que variaram das atividades pedagógicas, da alimentação até a participação no parque.

Em determinado encontro, a professora relatou que, quando assumiu a turma, não o percebia como um aluno de sua responsabilidade, por não se sentir preparada para ensiná-lo e em virtude da presença da agente educacional, mas que as discussões e reflexões do grupo a fizeram perceber o seu papel como professora. Percebeu também que, com planejamento e adaptações, é possível promover a participação de todos. Este foi um momento especial do programa, no qual foi possível observar a tomada de consciência da professora e o quanto o programa estava contribuindo para isso.

O desenvolvimento do programa de formação de professores na escola possibilitou uma análise de muitos aspectos que requerem alterações diretas no sistema educacional, como: efetivação de tempos e espaços para reflexão sobre a prática pedagógica, com orientação e acompanhamento institucionalizados; mudanças no sistema de efetivação dos professores possibilitando a criação de vínculos permanentes com a escola; sistematização da colaboração entre Educação Especial, escola e outros parceiros com vistas ao apoio específico a características individuais dos alunos, entre outros aspectos. Outra análise possível recai sobre a importância de tais ações, como as desenvolvidas no programa de formação, uma vez que, embora com vários percalços descritos anteriormente, a avaliação final desse período demonstra que a criação de um espaço de reflexão estabelecido na escola em que o professor atua, utilizando o estudo de seus alunos reais e discutindo coletivamente sua prática pedagógica à luz da teoria, foram fundamentais para a melhoria da atuação docente e para a construção de um ambiente de aprendizagem inclusivo.

A tão sonhada escola para todos, justa, democrática, equânime tem se apresentado, ainda que de forma tímida, demonstrando que as mudanças necessárias são possíveis, requerendo, no entanto, políticas e práticas condizentes com um novo paradigma. 


\section{Referências bibliográficas}

BRASIL. Constituição (1988). Constituição da República Federativa do Brasil. 10.ed. Brasília: Senado, 1998.

. Lei n.9.394, de 20 de dezembro de 1996. Estabelece as Diretrizes e Bases da Educação Nacional. Diário Oficial da União. Brasília. 23 dez. 1996. p.27.833-41.

Política Nacional de Educação Especial na Nacional Perspectiva da Educação Inclusiva. Disponível em: <http://portal.mec. gov.br/arquivos/pdf/politicaeducespecial.pdf>. Ministério da Educação/Secretaria de Educação Especial, 2007. Acesso em: 21 nov. 2011.

DRAGO, R. Inclusão na educação infantil. Rio de Janeiro: Wak Editora, 2011.

GIOVANNI, L. M. Do professor informante ao professor parceiro: reflexões sobre o papel da universidade para o desenvolvimento profissional de professores e as mudanças na escola. Caderno Cedes, Campinas, v.19, n.44, 1998.

MORIN, E. Os sete saberes necessários à educação do futuro. São Paulo: Cortez; Brasília: Unesco, 2011.

MOITA, M. C. Percursos de formação e de trans-formação. In: NÓVOA, A. Vidas de professores. Porto: Porto Editora, 2000.

NÓVOA, A. Nada substitui um bom professor: propostas para uma revolução no campo da formação de professores. In: GATTI, B. A. et al. (Orgs.). Por uma política nacional de formação de professores. São Paulo: Ed. Unesp, 2013.

. Profissão professor. Porto: Porto Editora, 1995.

PERRENOUD, P. A prática reflexiva no ofício do professor: profissionalização e razão pedagógica. Porto Alegre: Artmed, 2002.

RODRIGUES, D.; RODRIGUES, L. L. Formação de professores e inclusão: como se reformam os reformadores? In: RODRIGUES, D. Educação Inclusiva: dos conceitos às práticas de formação. Lisboa: Instituto Piaget, 2011.

SACRISTÁN, J. G. Consciência e acção sobre a prática como libertação profissional dos professores. In: NÓVOA, A. Profissão professor. Porto: Porto Editora, 1995. 
TARDIF, M. Saberes docentes e formação profissional. Petrópolis: Vozes, 2012.

; LESSARD, C. O trabalho docente: elementos para uma teoria da docência como profissão de interações humanas. Petrópolis: Vozes, 2013. 


\section{4 \\ O Programa de Educação de Jovens e Adultos (PEJA) EM Araraquara/SP: INTEGRANDO EXTENSÃO, PESQUISA E ENSINO}

Francisco José Carvalho Mazzeu

\section{Introdução}

O Programa de Educação de Jovens e Adultos (PEJA) foi criado formalmente na Unesp pela Portaria n.580, de 5 de dezembro de 2000. Compõe-se por projetos de extensão universitária que são desenvolvidos em sete câmpus, desde 2001.

Na Faculdade de Ciências e Letras da Unesp, câmpus Araraquara, o PEJA tem funcionado há mais de dez anos, e constitui-se como um espaço importante de articulação das atividades de extensão universitária com a pesquisa e o ensino. $\mathrm{O}$ projeto atua em três frentes principais: a) formação dos alfabetizadores de jovens e adultos do município de Araraquara; b) atuação direta em salas de aula de alfabetização, sob a responsabilidade de estudantes de graduação/bolsistas; c) parceria com duas escolas de EJA que atuam em todas as séries do ensino fundamental, por meio do Programa Institucional de Bolsas de Iniciação à Docência (Pibid), financiado pela Capes/MEC.

Este capítulo procura traçar um panorama das atividades que foram desenvolvidas especialmente nos últimos três anos, a partir das quais são apresentadas reflexões sobre o potencial desse tipo de 
iniciativa no sentido de promover a integração entre ensino, pesquisa e extensão na universidade, de forma a aproximar a instituição das questões e problemas colocados pela sociedade atual.

Vários autores (Santos, 2004; Torgal e Ésther, 2014) expressam a percepção de que a universidade pública no Brasil encontra-se em uma espécie de crise permanente em sua relação com a sociedade. De um lado, existe um conjunto de demandas de diferentes atores sociais, que nem percebem a universidade como possível parceira na busca de solução para os seus problemas ou não encontram caminhos para acessar a universidade; de outro lado, a instituição se enreda em problemas internos como burocracia, produtivismo e outras mazelas que tornam a atividade acadêmica no ensino e na pesquisa distante ou até divorciada da dinâmica da sociedade local, regional e nacional.

Nesse contexto, a extensão universitária assume papel fundamental ao colocar a instituição em sintonia com as necessidades sociais, provocando a pesquisa a produzir conhecimentos relevantes e adequados a essa realidade, bem como estimulando o ensino a formar os profissionais que poderão contribuir para a melhoria das condições de vida da população e para o desenvolvimento do país.

A educação de jovens e adultos revela-se um tema de enorme importância nesse cenário. O Brasil é um dos países do mundo que mais tem encontrado dificuldade para oferecer um patamar mínimo de educação formal para a população. O número de 13,3 milhões de adultos analfabetos, $8,5 \%$ da população, mostra que o país ainda precisa desenvolver e implementar políticas públicas com soluções mais rápidas e eficazes desse grave problema educacional e social. Embora não seja obrigação legal da universidade atuar diretamente nesse nível de ensino, é evidente que ela pode (e deve) desempenhar um papel tanto na formulação e execução de projetos e programas quanto na produção de conhecimentos, métodos e outros meios que contribuam para o sucesso das iniciativas de alfabetização de adultos. 


\section{A atuação extensionista do PEJA e a função social da universidade}

Nesse sentido, um dos principais desafios do PEJA é contribuir para a redução do analfabetismo em Araraquara e região. Apesar de estar situado em um dos locais mais desenvolvidos e prósperos do Brasil, o município ainda apresenta um quadro de desigualdades sociais e educacionais significativas. Segundo o censo IBGE de 2010, 6.161 pessoas com idade acima de 15 anos se declararam analfabetas, correspondendo a $3,62 \%$ da população local.

Embora os índices de analfabetismo sejam bem menores que em outras regiões brasileiras e estejam em declínio nos últimos vinte anos, essa redução tem se dado em ritmo cada vez mais lento. De acordo com os dados do IBGE, houve uma diminuição mais intensa da taxa de analfabetismo em Araraquara no período de 1991 a 2000 , passando de $8,6 \%$ para $5,2 \%$, representando uma redução de 2.980 pessoas no número absoluto de analfabetos, ao passo que entre 2000 e 2010 o índice caiu em torno de 1,5 ponto percentual, uma diminuição, em números absolutos, de apenas 1.135 pessoas (Braga, 2015). Se, por um lado, é natural que a redução do analfabetismo aumente as dificuldades para atingir esse público, por outro, há que se questionar a eficácia das políticas públicas implementadas nesse campo e buscar formas de aprimorar seus resultados. Por exemplo, menos de $10 \%$ dos analfabetos identificados pelo censo no município estão atualmente matriculados no Programa Brasil Alfabetizado (PBA), realizado por meio de parceria entre o governo federal e o municipal, que é a principal política pública em execução nesse setor. Além da baixa adesão, outro desafio desse programa são os altos índices de evasão e de retenção.

Para colaborar nesse desafio da superação do analfabetismo, o PEJA, desde 2011, vem construindo parceria com o município para fortalecer a execução do PBA, atuando diretamente em salas de aula do programa e coordenando a formação continuada da equipe de alfabetizadores e alfabetizadoras, supervisores e técnicos envol- 
vidos. Essa parceria da Unesp com o poder público municipal, com estratégia de médio e longo prazo, cria condições mais favoráveis para conseguir resultados efetivos tanto no âmbito das políticas públicas, quanto na forma de atuação da universidade. Cabe ressaltar que a construção desse tipo de parceria demanda forte investimento de tempo, pois implica inúmeras reuniões e atividades conjuntas para que as partes envolvidas possam se conhecer e conciliar a dinâmica e a lógica própria de cada instituição envolvida.

A ação extensionista do PEJA procura se pautar pelas orientações e princípios do Plano Nacional de Extensão Universitária, construindo uma via de mão dupla com a comunidade de modo que os "beneficiários" sejam sujeitos participantes das decisões. Essa relação é baseada em um permanente diálogo com todos os envolvidos, implicando transparência em relação aos objetivos previstos, discussão aberta dos problemas, mudanças e outros aspectos que afetam o andamento das atividades, entre outras medidas.

No que se refere à atuação direta junto aos alfabetizandos, o PEJA está responsável desde 2010 por duas salas de aula, situadas em escolas da periferia, nas quais os bolsistas atuam como alfabetizadores. Nas salas de aula em que atuam diretamente, os bolsistas do PEJA têm a oportunidade de aplicar atividades didáticas e materiais de apoio elaborados sob a orientação de docentes da Unesp. Esses recursos didáticos são produzidos a partir de orientações teórico-metodológicas inspiradas no pensamento de Paulo Freire e outros autores. Ao longo do tempo, foram criadas centenas de atividades voltadas para a fase inicial da alfabetização de adultos, utilizando diversos recursos, desde materiais impressos convencionais, na forma de folhas a serem preenchidas pelos alunos, até vídeos, programas usados em aparelhos de telefonia celular e outras opções que podem dinamizar o trabalho em sala de aula. Todas as atividades e materiais são exaustivamente analisados e debatidos nas reuniões da equipe do PEJA, de modo que sua utilização em sala de aula traga os melhores resultados possíveis.

Os resultados são altamente positivos. Por exemplo, o índice de evasão nas salas de aula organizadas pelo PEJA é inferior a 10\% ao 
longo do ano, ao passo que nas demais salas do município apresenta uma média superior a 50\%, chegando a mais de $70 \%$ em alguns locais. Também foram identificados resultados promissores no atendimento a alunos com dificuldades especiais de alfabetização, que eram retidos por não conseguirem avançar em seu aprendizado.

As atividades e materiais didáticos elaborados por meio desse processo de investigação teórico-prática são socializados com os demais alfabetizadores do município por meio de um trabalho de assessoria e formação dos alfabetizadores, realizado em parceria com a prefeitura municipal e com a ONG Proeaja (que atua em convênio com a prefeitura na seleção, concessão de bolsas e formação dos alfabetizadores do Programa Brasil Alfabetizado).

O PEJA atua no apoio para a definição do perfil dos alfabetizadores, orientações sobre a aplicação/correção de uma prova escrita de seleção de alfabetizadores e coordenação das atividades de formação inicial e continuada desses alfabetizadores. Até o momento, já foram formados 22 alfabetizadores, que trabalham com 410 alunos das salas de alfabetização. Por meio desse processo formativo, os estudos e pesquisas feitos na universidade geram um impacto positivo no processo de redução do analfabetismo no município. Após o início da parceria da Unesp com a prefeitura e a ONG, em 2011, os resultados obtidos pelas alfabetizadoras melhoraram significativamente, como se vê pelos dados a seguir:

\begin{tabular}{|c|c|c|c|}
\hline Ano & Matriculados & Total de aprovados & Taxa de aprovação \\
\hline 2009 & 441 & 23 & $5,21 \%$ \\
\hline 2010 & 349 & 54 & $15,47 \%$ \\
\hline 2011 & 381 & 195 & $51,18 \%$ \\
\hline 2012 & 427 & 173 & $40,51 \%$ \\
\hline
\end{tabular}

Fonte: Sistema Brasil Alfabetizado/Prefeitura Municipal de Araraquara.

Os dados de 2013 e 2014, embora ainda não estejam disponíveis no sistema, apontam para a manutenção desse patamar, que é bastante superior à média nacional obtida no âmbito do Programa 
Brasil Alfabetizado. No ano de 2014, Araraquara recebeu o selo de "território livre do analfabetismo". Embora esse selo seja decorrente dos dados do censo de 2010, a parceria com a Unesp contribuiu para consolidar esse resultado.

O que é destacado pelas próprias alfabetizadoras é que o processo de formação continuada traz orientações práticas, voltadas à realidade do educando adulto e das salas de aula existentes, com sugestão de atividade e materiais de apoio que ajudam a tornar mais sistemático e motivador o trabalho de alfabetização. Com isso, os alunos se sentem mais motivados a permanecer e fazem uma divulgação positiva, contribuindo para atrair novos estudantes.

É possível perceber a importância e o potencial de atuação da universidade para a solução de um dos graves problemas educacionais do país: o analfabetismo. Essa experiência mostra a necessidade de combinar uma atuação no nível "micro", com foco em um pequeno grupo de alfabetizandos que possam receber a atenção dos bolsistas do projeto, gerando um conhecimento da situação e resultando na elaboração de propostas adequadas a essa realidade, com uma atuação em nível mais "macro", criando parcerias com o poder público e outros atores sociais para que as políticas obtenham melhores resultados, gerando assim um ambiente propício para que as propostas formuladas pela universidade atinjam uma escala mais ampla, produzindo impactos sociais maiores e mais duradouros.

Dessa forma, a ação extensionista do PEJA, ao mesmo tempo que serve de ponto de partida e de lócus para a produção de conhecimentos, é baseada e fundamentada nos resultados da própria investigação e de outros estudos e pesquisas disponíveis na universidade, de modo que a extensão assegura a relevância da pesquisa e esta fundamenta a qualidade da atuação extensionista. 


\section{A pesquisa e a produção de conhecimento no PEJA}

Do ponto de vista metodológico, o projeto se insere nos quadros da pesquisa-ação, uma vez que os procedimentos e materiais didáticos utilizados na formação dos alfabetizadores do município são produzidos a partir do trabalho dos bolsistas nas salas de alfabetização coordenadas pelo PEJA. Ao mesmo tempo, essa produção é apresentada aos professores do Programa Brasil Alfabetizado como sugestão a ser debatida e reconstruída por eles a partir da sua experiência e conhecimentos.

É possível perceber que essa dinâmica se orienta pela categoria dialética da práxis, procurando estimular tanto os professores quanto os bolsistas (futuros professores também) a desenvolverem seus próprios instrumentos de trabalho didático com base em estudos sistemáticos. Por meio desse instrumental de ensino, o professor pode mais facilmente dirigir a sua própria atividade para alcançar os objetivos e resultados a que se propôs. Dessa forma, os instrumentos de trabalho docente, elaborados por ele mesmo em um processo de trocas e debates, atuam como mediadores essenciais na transformação dos conteúdos já assimilados pelos alunos (em termos de conhecimentos, habilidades, valores e atitudes) de modo que eles desenvolvam os conteúdos que a escola precisa ensinar.

Os conceitos de mediação (Marx, Vigotsky) e de diálogo (Freire, Bakhtin) são fundamentais para orientar tanto a atuação dos docentes e estudantes diante do grupo de alunos em processo de alfabetização quanto para definir a metodologia dessa formação. Dessa maneira, ao mesmo tempo que o PEJA gera resultados de pesquisa na forma de instrumentos didáticos e de dados sobre a realidade da alfabetização de adultos no município, a formação dos estudantes proporcionada pelo projeto procura formar educadores/pesquisadores capazes de elaborar e reelaborar coletivamente os seus instrumentos de trabalho, analisando e compreendendo as concepções educacionais que estão objetivadas nesses instrumentos e se constituindo como autores das suas próprias opções metodológicas. 
Pautado nas colaborações de Paulo Freire e outros autores, o objetivo do trabalho de alfabetização nas escolas parceiras é elaborar instrumentos teórico-práticos que contribuam para melhorar o processo de alfabetização realizado na rede de ensino municipal, especialmente as ações desenvolvidas no âmbito do Programa Brasil Alfabetizado, sendo que uma das demandas detectadas pela investigação entre os professores desse programa refere-se à carência de materiais didáticos e atividades adequadas às necessidades, expectativas e conhecimentos dos educandos adultos. Como parte de um esforço de construção coletiva, vem sendo criado e testado um Caderno de Alfabetização formado por textos e atividades, elaboradas por meio de um diálogo permanente entre a equipe da FCL e os professores envolvidos.

O Caderno de Alfabetização consiste de três momentos básicos: a discussão sobre uma palavra geradora; o estudo sistemático das sílabas contidas nessa palavra (silabação, exercício dos fonemas, formação de novas sílabas e palavras, formação de frases) e a produção de um novo texto. $\mathrm{O}$ primeiro momento procura contextualizar a palavra geradora para que ela adquira sentido para o alfabetizando adulto. Essa dimensão semântica facilita a memorização dos fonemas e letras estudados. No segundo momento, faz-se um estudo sistemático dessa palavra, identificando suas sílabas e fonemas, criando novas sílabas, exercitando o desenho das letras e formando novas frases. No terceiro momento, busca-se retomar o texto gerador, recriando esse texto.

O trabalho nas salas de aula coordenadas pelo PEJA procura seguir essa dinâmica, porém com a clareza da necessidade de adaptar as atividades propostas aos temas e questões trazidos pelos educandos. A produção de um material didático para a alfabetização, que substitua as tradicionais cartilhas, possui grande importância como produto do trabalho de pesquisa, pois possibilita disseminar os resultados dessa pesquisa de modo mais fácil e direto. Ao mesmo tempo, o material didático possui em sua arquitetura a objetivação de avançados estudos teóricos e metodológicos. Trata-se de produzir uma inovação tecnológica baseada nos conheci- 
mentos atuais sobre os processos de ensino-aprendizagem dos educandos adultos, a natureza do sistema de linguagem escrita, os determinantes sociológicos do analfabetismo e outros fundamentos científicos que possam orientar o trabalho dos alfabetizadores para a obtenção dos melhores resultados possíveis nas condições existentes.

Além desse processo geral de investigação e da produção do Caderno de Alfabetização, o contato permanente com a realidade das salas de aula de alfabetização instiga os bolsistas e mestrandos envolvidos a pesquisarem temas de interesse nessa área, a partir de problemas reais vivenciados no âmbito do programa. Questões como: dificuldades de memorização dos educandos adultos, o perfil dos alunos e dos professores do PBA, os motivos dos alunos para estudar e permanecer na escola, o uso do celular em atividades didáticas, entre muitos outros, foram objeto de estudo pelos bolsistas, resultando em doze trabalhos apresentados em eventos nos últimos três anos, além de uma dissertação de mestrado recentemente defendida no Programa de Pós-Graduação em Educação Escolar da FCL.

O processo de pesquisa desenvolvido volta-se tanto na geração de novos conhecimentos e produtos quanto na preparação de jovens pesquisadores. Ainda que estes não venham a se dedicar ao trabalho investigativo por meio da pós-graduação, poderão aproveitar esse despertar do interesse pela pesquisa como um eixo articulador da sua formação como educadores. A pesquisa, entendida como produção de novos conhecimentos e formação de produtores de conhecimentos, ajuda a qualificar o trabalho dos futuros professores, complementando sua formação acadêmica oferecida pelos cursos de licenciatura da universidade.

\section{O ensino e a formação de professores no âmbito do PEJA}

Via de regra, os processos formativos acabam reduzindo o educador a um aplicador de métodos e técnicas ou alimentam-no com teorias e orientações gerais que ele teria que "traduzir" por conta 
própria em suas atividades didáticas. Essa tradução em geral se mostra muito difícil, produzindo uma assimilação de tais teorias mais como um discurso ou como "clichês" cujo significado o próprio educador não domina (Mazzeu, 1999). Com isso, as atividades práticas e os procedimentos corriqueiros usados na alfabetização de adultos (e também na de crianças) muitas vezes permanecem refratários às mudanças efetivas almejadas pelos processos de formação inicial e continuada.

O PEJA procura atuar na formação de professores que possam romper com essas estruturas alienadas de trabalho, provocando um constante questionamento sobre a prática em sala de aula e as possibilidades viáveis de transformação dessa prática. Para tanto, atua em duas frentes: na formação inicial e continuada dos alfabetizadores do PBA e na formação dos graduandos de licenciatura da FCL que serão futuramente os professores da rede de ensino fundamental e poderão atuar na alfabetização de jovens e adultos.

A formação de professores alfabetizadores coloca vários desafios. De um lado, é necessário tomar as questões da prática de ensino como ponto de partida e de chegada dos debates formativos, gerando uma apropriação mais significativa dos fundamentos teórico-metodológicos envolvidos na aquisição da linguagem escrita. Para tanto é preciso conhecer a realidade onde os professores atuam e as possibilidades de trabalho nas salas de alfabetização do município, por meio de visitas aos locais de realização do PBA. Além disso, com debates periódicos em um "círculo de reflexão", os alfabetizadores podem assumir um papel de sujeitos da elaboração dos fundamentos do seu trabalho e na transformação da sua prática.

No que se refere à formação de graduandos como futuros alfabetizadores e professores de EJA, o projeto atua em articulação com o Pibid, financiado pela Capes. ${ }^{1}$

1. Os trechos a seguir reproduzem, com modificações, trechos da apresentação de um Manual Didático (Fonseca; Mazzeu; Rosa, 2015) desenvolvido no âmbito do projeto. 
A área de EJA possui uma demanda concreta por educadores formados para essa modalidade, que possam compreender as especificidades do processo de aprendizagem dos jovens e adultos e selecionar ou elaborar atividades didáticas adequadas a esse público.

De modo geral, os cursos de licenciatura da faculdade estão distantes dessa demanda, uma vez que praticamente não são oferecidas disciplinas com esse tema, nem mesmo como optativas, gerando uma lacuna significativa na preparação desses profissionais. Ainda que muitos desses professores não venham a atuar diretamente com a EJA, sua formação nesse campo poderia trazer uma importante contribuição para a compreensão geral dos fenômenos educacionais, especialmente os problemas que resultam na evasão escolar e das formas de valorizar a cultura dos alunos na escola regular, assim como para facilitar a relação com os pais dos alunos e a interação com a comunidade em que estão inseridos.

$\mathrm{Na}$ preparação de professores para a EJA, um dos aspectos fundamentais consiste em fazer a articulação dos conteúdos escolares com a experiência de vida dos alunos, por meio de temas geradores (tal como proposto por Paulo Freire), de modo a extrair da realidade social e econômica vivida pelos adultos questões problematizadoras que darão sentido ao estudo de saberes científicos. Portanto, o trabalho docente na EJA já requer uma abordagem interdisciplinar, o que representa excelente oportunidade de vivenciar práticas integradoras que poderão ser aplicadas também no ensino regular.

O objetivo do projeto Educação de Jovens e Adultos: o Letramento Crítico como Base para uma Abordagem Interdisciplinar realizado no âmbito do Pibid é possibilitar aos educadores em formação e demais participantes a vivência de uma práxis transformadora das práticas escolares, por meio de um trabalho interdisciplinar que parta de objetos educacionais diversos (textos, imagens, vídeos), promova a leitura crítica desses objetos a partir dos conceitos de diferentes áreas do conhecimento (Linguagem, História, Geografia etc.) e gere a produção de novos objetos, bem como a assimilação significativa do saber escolar. 
O projeto se desenvolve em duas escolas da rede pública municipal: Escola Municipal de Ensino Fundamental Rubens Cruz e o Núcleo de Educação de Jovens e Adultos Irmã Edith. Essas escolas são aquelas que possuem o maior número de salas de EJA no município. A Emef Rubens Cruz (ex-Caic) está situada na periferia da cidade, em bairro populoso e possui salas da $4^{\mathrm{a}}$ série até a $8^{\mathrm{a}}$ série o que assegura a sua inserção nesse tema pelos próximos anos. Atende a 929 alunos, sendo 112 na modalidade de EJA. O Neja Irmã Edith situa-se na área central, dado que se constitui em espaço que concentra as atividades de EJA no município, atendendo a educandos oriundos de todos os bairros da cidade. Nesse centro são atendidos 306 alunos. Além do apoio das equipes de direção e coordenação, da Secretaria Municipal de Educação, o projeto conta com a participação de cinco professores das escolas parceiras, que atuam como supervisores das atividades, fazendo uma mediação fundamental entre a universidade e as escolas.

O projeto se articula em torno do eixo interdisciplinar dos mitos gregos e africanos. Esse tema vem sendo abordado tanto em atividades voltadas ao trabalho com as várias disciplinas do currículo quanto em atividades de enriquecimento curricular e extracurricular. Essas ações dialogam com os estudos da literatura clássica desenvolvidos no curso de Letras da FCL, com a introdução de elementos da cultura africana previstos na Lei n.10.639/2003, alterada pela Lei n.11.645/2008, que torna obrigatório o ensino da história e cultura afro-brasileira e africana em todas as escolas e com a elaboração de atividades didáticas a partir de objetos culturais desenvolvida nos cursos de Pedagogia e de licenciatura em Ciências Sociais. As principais atividades do projeto são:

- levantamento de bibliografia e materiais didáticos relativos à mitologia grega e africana;

- levantamento de materiais didáticos e recursos já disponíveis nas escolas parceiras sobre esse tema;

- criação de um acervo de materiais multimídia que trazem releituras contemporâneas de mitos da Antiguidade grega e 
dialogam com as tradições africanas, dando especial destaque à figura do herói nesses mitos, pela sua importância e repercussão em áreas como História e Ciências;

- realização de atividades de campo (visitas e outras) pelos alunos de EJA, com apoio dos bolsistas;

- produção, pelos bolsistas e supervisores, de um conjunto de propostas de atividades didáticas que exploram conteúdos curriculares a partir desse acervo e do tema integrador;

- aplicação dessas atividades didáticas pelos professores de EJA, com apoio e colaboração dos bolsistas e supervisores;

- elaboração e manutenção, pelos bolsistas e supervisores, de um site contendo materiais selecionados ou produzidos por eles, sugestões de leituras, vídeos etc.;

- apresentação e discussão dos resultados do projeto em eventos regionais e nacionais;

- realização de reuniões semanais com os bolsistas e quinzenais com a equipe de supervisão, além de reuniões mensais com a equipe gestora das escolas parceiras.

Essas ações consideram a formação de professores como um processo de permanente reflexão crítica sobre a realidade da escola e busca de instrumentos para uma intervenção transformadora. Essa proposta está coerente com as orientações dos projetos político-pedagógicos dos cursos de licenciatura da FCL, que defendem uma integração entre teoria e prática durante essa formação, ao mesmo tempo que o Pibid poderá influenciar esses cursos, indicando formas de fortalecer essa integração.

O principal meio de registro e acompanhamento das atividades é uma rede social, com um grupo fechado destinado a receber as postagens dos bolsistas, supervisoras e coordenadores do projeto. Nesse grupo são inseridas fotos, vídeos, arquivos e, principalmente, relatos e comentários dos participantes. Essas postagens compõem um "portfólio virtual" de cada bolsista e do projeto como um todo. Periodicamente, esse material é sistematizado para extrair questões de pesquisa e resultados do trabalho. Futuramente, será criado um 
grupo aberto, no qual poderão participar professores da rede, estudantes de graduação, alunos de EJA e demais interessados no projeto e na área. Nesse grupo serão postadas informações sobre o andamento das atividades, chamadas para eventos, materiais didáticos elaborados, links e sugestões para melhorar o trabalho nas salas de aula de EJA e outros elementos que promovam a reflexão e o aprimoramento dessa modalidade de ensino.

O projeto aposta na construção da autonomia e da responsabilidade dos futuros docentes. Sendo assim, os eventuais problemas e decisões sobre o andamento das atividades são debatidos em reuniões semanais de planejamento e avaliação com todos os bolsistas. Nessas reuniões são destacados casos específicos vivenciados nas escolas para serem abordados à luz de uma reflexão crítica e fundamentada na pesquisa educacional. A partir de um diagnóstico das escolas e salas de aula, é feito um planejamento das intervenções, com ênfase na participação ativa dos bolsistas e criação de redes colaborativas com os professores e a equipe escolar.

Esse planejamento também procura considerar o plano de trabalho dos professores e o projeto político-pedagógico da escola. Cada bolsista vai elaborando um conjunto de tarefas a serem desenvolvidas como decorrência desse planejamento. Com a sistemática de postagem na internet das atividades realizadas é possível acompanhar e avaliar a realização dessas atividades, fazendo os comentários adequados para promover correções e incentivar as práticas mais inovadoras e produtivas.

Os desafios mais complexos ou avanços mais significativos são objeto de debates específicos e leitura de textos de fundamentação. Periodicamente são feitos seminários temáticos abordando com mais profundidade aspectos do obejto central do projeto. Dessa forma, é trabalhada a formação da consciência crítica desses futuros educadores, para que eles possam compreender a realidade da escola e da sala de aula em seus aspectos contraditórios e nas suas múltiplas determinações sociais. Consequentemente, espera-se estimular nos bolsistas uma atitude ético-política de compromisso com a educação, que se expressa por meio de presença nas 
atividades (evitando o absenteísmo), cumprimento dos horários, empenho em obter os melhores resultados possíveis (busca da excelência), interesse pelo aprendizado de cada educando(a) etc.

A preparação de atividades didáticas possui um caráter estratégico na formação desses futuros professores, pois promove atividades de leitura, análise, comparação, seleção e produção de textos e outros materiais escritos e permite a produção de instrumentos didáticos adequados para a realização de seus objetivos educacionais. Os participantes do projeto são incentivados a apresentar e debater essas atividades e sequências didáticas em reuniões com colegas, coordenadores e professores da escola, tendo que desenvolver argumentos que justifiquem a adequação e a relevância de cada material escolhido ou elaborado. $\mathrm{O}$ uso de redes sociais para a postagem dos materiais também facilita a realização de comentários e debates. Os coordenadores e supervisores atuam nessas redes como mediadores, avaliando os conteúdos e a linguagem e estimulando o aprofundamento e a melhoria dessas produções.

Dessa forma, o projeto se apoia em uma habilidade já desenvolvida por muitos estudantes de graduação, que utilizam constantemente a internet como canal de socialização e expressão, para promover avanços nas atividades de leitura e produção de texto, reflexão e debate que esses jovens já realizam. Essas atividades vêm evoluindo de comentários e postagens simples, resumos de atividades etc., para análises mais rigorosas e teoricamente fundamentadas, resultando em textos acadêmicos a serem apresentados em eventos e enviados para publicação. Espera-se que a experiência na escola possa também ser utilizada pelo bolsista como referência para a produção de trabalhos escolares, TCCs (no caso dos cursos de Ciências Sociais e Letras), projetos de iniciação científica, bem como os projetos e relatórios de estágio curricular supervisionado.

Dessa forma, o PEJA tem se constituído como um facilitador da construção de espaços e projetos de formação de professores, tanto voltados a estudantes da universidade quanto voltados a professores que já atuam na rede de ensino. Nesses espaços são gestadas novas práticas de ensino, baseadas em pressupostos e valores 
inovadores, de modo que os profissionais que passam por tais experiências venham a se constituir em agentes transformadores da realidade escolar em que atuam ou irão atuar.

\section{Considerações finais}

No presente texto foram apresentadas as principais linhas de atuação do PEJA. O que se pode perceber pela descrição dessas atividades, embora sucinta, é a existência de um enorme potencial do projeto para a construção de caminhos de integração da extensão universitária com a pesquisa e o ensino.

Isso ocorre porque o projeto de extensão está focado em um problema específico e socialmente relevante como é o caso do analfabetismo entre adultos. No enfrentamento desse problema é importante atuar tanto na produção de novos conhecimentos, elaborados com rigor acadêmico, quanto na ampla disseminação desses conhecimentos, para que seja possível alcançar resultados de maior impacto social. Para tanto, é essencial que haja uma articulação com outros atores sociais, especialmente o poder público local, de modo que a universidade insira a sua ação extensionista no bojo de políticas públicas existentes, contribuindo para melhorar sua formulação e execução.

Assim, o projeto de extensão produz resultados muito mais amplos e duradouros nos espaços sociais em que se insere. Essa articulação com as políticas públicas é extremamente desafiadora e nem sempre a universidade está preparada para enfrentar esse desafio. Há que se construir parcerias com instituições que trabalham com lógicas e tempos muito diferentes da universidade, construir relações de confiança com os agentes envolvidos e trabalhar em uma perspectiva de médio e longo prazo.

Essa articulação esbarra em diversos obstáculos, dentre eles a própria dificuldade da universidade para compreender e assumir o caráter estratégico das ações de extensão e oferecer condições para que os projetos possam se desenvolver durante o tempo necessário 
para a construção desses espaços sociais integrados e integradores e dessas relações de parceria.

O PEJA, por enquanto, consegue vencer esses desafios, apoiado em parte na captação de recursos externos. Na medida em que as atividades de extensão do projeto se consolidam, construindo um programa com relativa estabilidade, criam-se condições favoráveis para que essas atividades exerçam uma influência positiva na produção de conhecimentos e na formação de professores e pesquisadores para a EJA, no âmbito da FCL.

Considerando a prioridade para a educação estabelecida nos discursos oficiais e a enorme demanda por uma educação de qualidade para jovens e adultos, pode-se concluir que existe uma oportunidade ímpar para que a universidade assuma um papel estratégico na transformação desse discurso em realidade, por meio de projetos e programas como o PEJA.

\section{Referências bibliográficas}

BRAGA, A. C. O desafio da superação do analfabetismo no Brasil: uma análise do Programa Brasil Alfabetizado no município de Araraquara/SP. Araraquara, 2015. Dissertação (Mestrado) - PPGEE/ FCL/Unesp.

FONSECA, D. J.; MAZZEU, F. J. C.; ROSA, E. B. da. Os mitos gregos e africanos na Educação de Jovens e Adultos: Manual Didático. Araraquara: FCL-Unesp, 2015.

MAZZEU, F. J. C. Os "clichês” na prática de ensino: o que há por trás desse problema? São Carlos, 1999. Tese (Doutorado) - Universidade Federal de São Carlos (UFSCar).

SANTOS, B. S. A universidade do século XXI: para uma reforma democrática e emancipatória. São Paulo: Cortez, 2004.

TORGAL, L. R.; ÉSTHER, A. B. Que universidade? Interrogações sobre os caminhos da universidade em Portugal e no Brasil. Juiz de Fora: EDUFJF, 2014. 


\section{5 \\ Apoio e deSEnVOLVIMENTO AO Observatório Cidadão de PIRACICABA: extensão, FORMAÇÃO E CIDADANIA}

Carla Gandini Giani Martelli
Wagner de Melo Romão

\section{Introdução}

Este trabalho tem como objetivo mostrar alguns resultados do projeto de extensão desenvolvido junto ao Observatório Cidadão de Piracicaba. Desde sua fundação, em dezembro de 2012, a Faculdade de Ciências e Letras da Unesp, câmpus Araraquara, está envolvida com o projeto de desenvolvimento e apoio ao Observatório, com outras seis instituições da cidade - Imaflora, OAB, Pasca, Casvi, Florespi e Pira 21 -, além do Instituto de Geociências e Ciências Exatas da Unesp, de Rio Claro.

O Observatório nasceu com o objetivo de ser uma inovadora ferramenta de controle social que sirva como um dos principais mecanismos de análise e sistematização das políticas públicas do município e da qualidade de vida local. A partir de um conjunto de dados, informações e análises, agrupados em diferentes módulos de observação, busca-se instrumentalizar a sociedade para melhor compreensão e participação nos processos decisórios locais e contribuir com o monitoramento, a avaliação e o aprimoramento das políticas públicas do município. 
Além de participar da secretaria executiva do Observatório, instância principal de sua governança, o projeto de extensão comprometeu-se a colaborar com três eixos de ação definidos pelo Observatório como prioritários: a) monitoramento das instituições públicas, das políticas públicas e da qualidade de vida do município, por meio da geração de informações, de indicadores e de análises; b) elaboração de propostas para o aprimoramento das políticas e das instituições públicas; c) educação para a participação e o controle social. Durante o ano de 2013, contribuiu-se com o primeiro eixo por meio do acompanhamento de conferências municipais de políticas públicas.

O Observatório é o único do estado de São Paulo, e possivelmente do Brasil, que monitora de forma ampla e sistemática os principais instrumentos institucionais de participação existentes no nível local, em especial audiências públicas, conferências, conselhos municipais e orçamento participativo. O intuito é monitorar esses espaços, demonstrando seus pontos fortes e suas fragilidades e dar publicidade às propostas aprovadas pelos mesmos (Romão et al., 2014). ${ }^{1}$ Em 2014, foi a vez do projeto De Olho no Legislativo, que teve como objetivo avaliar o desempenho dos vereadores da Câmara Municipal de Piracicaba nos anos de 2013 e 2014, por uma série de competências e indicadores, visando à geração de um ranking de desempenho dos mesmos como base de análise para a opinião pública e para a sociedade civil. ${ }^{2}$

1. Os resultados do acompanhamento de sete conferências que aconteceram em Piracicaba entre os meses de abril e julho de 2013 serão mostrados neste capítulo.

2. Os resultados serão mostrados mais à frente. 


\section{Sobre as conferências ${ }^{3}$}

As conferências são instâncias de participação social que têm por objetivo institucionalizar a participação da sociedade nas atividades de planejamento, controle e gestão de determinada política ou de um conjunto de políticas públicas. Participam desses espaços representantes da sociedade e do poder público. As conferências funcionam de forma escalonada, com etapas preparatórias locais e distritais, municipais, estaduais e nacional.

No município, são discutidas e elaboradas propostas de políticas relacionadas ao tema da conferência, posteriormente enviadas à etapa estadual, além de eleger representantes da próxima etapa (delegados). Nas conferências estaduais, são eleitas as propostas enviadas à etapa nacional e novos delegados são escolhidos pelos participantes. Por fim, na conferência nacional, escolhem-se as propostas finais daquela conferência. Além de instituições participativas, estas são consideradas instituições representativas e deliberativas no sentido de gerar dinâmicas de representação da sociedade civil e de compor de forma mais complexa a estrutura de representação política no âmbito do Estado e de seus poderes, abrindo novos espaços de influência da sociedade civil, para além das formas mediadas por meio do voto e dos partidos políticos.

Algumas conferências são regulamentadas por lei (por exemplo, as conferências nacionais, estaduais e municipais da saúde e da assistência social); outras são regulamentadas por decreto do Poder Executivo, e há ainda aquelas que não possuem nenhum instrumento de institucionalização que obrigue a sua realização.

A seguir, alguns dados referentes a sete conferências municipais ocorridas no município de Piracicaba (SP), ao longo do ano de 2013, a saber, Assistência Social, Cultura, Educação, Igualdade Racial, Cidades, Esporte e Meio Ambiente. A partir da análise de mais de quatrocentos questionários respondidos pelos conferen-

3. Participaram desta pesquisa a docente Camila Fernanda Bassetto e os alunos bolsistas do projeto: Guilherme Efraim Virgili, Thais Matheus e Bruno Vello. 
cistas, o objetivo foi traçar os perfis socioeconômico, associativo e político dos participantes de cada conferência.

\section{Indicadores de perfil socioeconômico}

O gráfico mostra as singularidades das áreas de políticas públicas para avaliação dos resultados: há presença massiva de mulheres nas áreas de Assistência Social e Educação, assim como forte presença masculina na conferência de Esporte, conforme tradição das áreas. Com exceção das conferências da Assistência Social, da Educação, e da conferência do Meio Ambiente com 58\% de mulheres, constatou-se maior presença masculina nas conferências do Esporte e das Cidades e certo equilíbrio de gênero nas conferências da Igualdade Racial e Cultura.

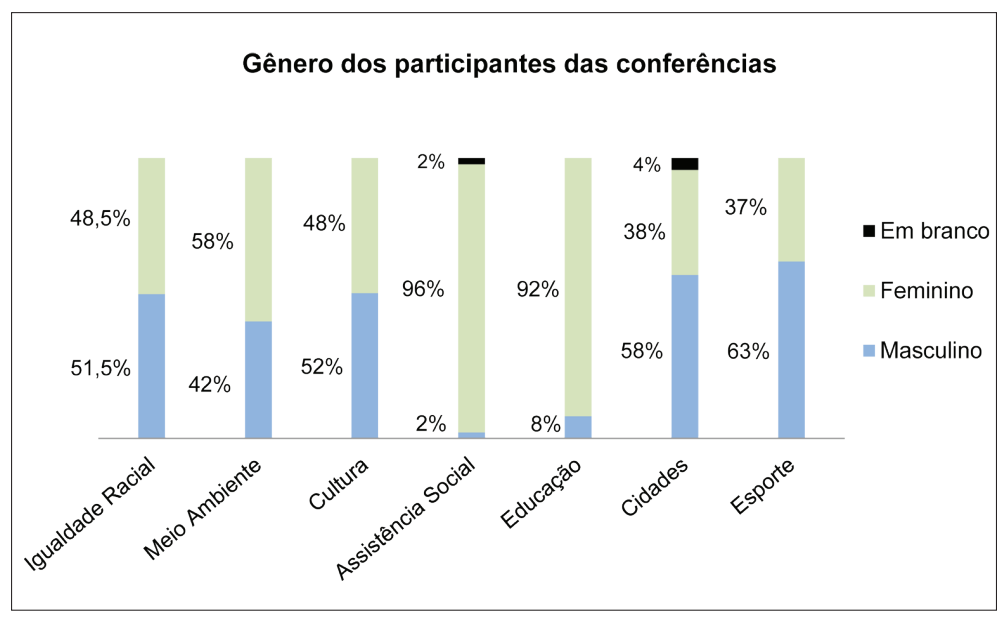

Gráfico 5.1 - Fator gênero (em \%)

Com exceção da conferência do Meio Ambiente, que apresenta a maioria de jovens, o grupo mais representativo nas demais está entre 41 e 53 anos, seguido do grupo com idade entre 28 e 40 anos. Nota-se a existência de uma sub-representação de jovens e de pessoas com mais de 70 anos. 


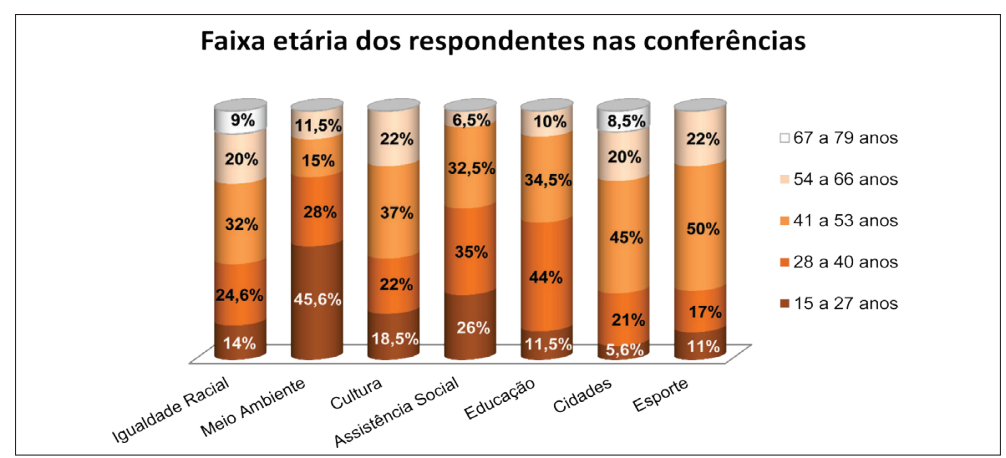

Gráfico 5.2 - Fator idade (em \%)

A participação de brancos prevalece sobre a de pretos e pardos (categorias utilizadas pelo IBGE), com exceção da Igualdade Racial, que traz $62 \%$ de pretos.

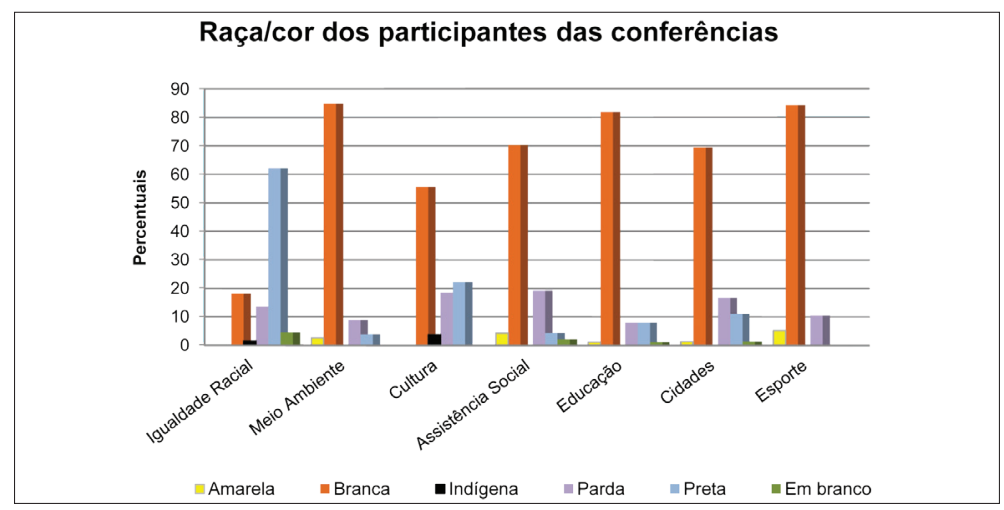

Gráfico 5.3 - Fator raça/cor (em \%)

Chama a atenção a conferência da Assistência Social com 76\% dos participantes com ensino superior completo, seguida do Esporte com 63\% e da Educação, com 57\%. As demais estão abaixo de 50\%. Um dado relevante é o da conferência da Educação na qual $26 \%$ dos participantes têm pós-graduação stricto senso, seguida da Cultura, com 19\%, e das Cidades, com 17\%. As demais ficam 
abaixo de 10\%. A conferência da Igualdade Racial é a que apresenta o maior número de participantes sem ensino médio completo (12\%). Também chama a atenção a conferência do Meio Ambiente, com o percentual de $43 \%$ dos conferencistas com ensino superior incompleto, provavelmente relacionado à elevada participação de pessoas menores de 27 anos, como aponta o Gráfico 5.2.

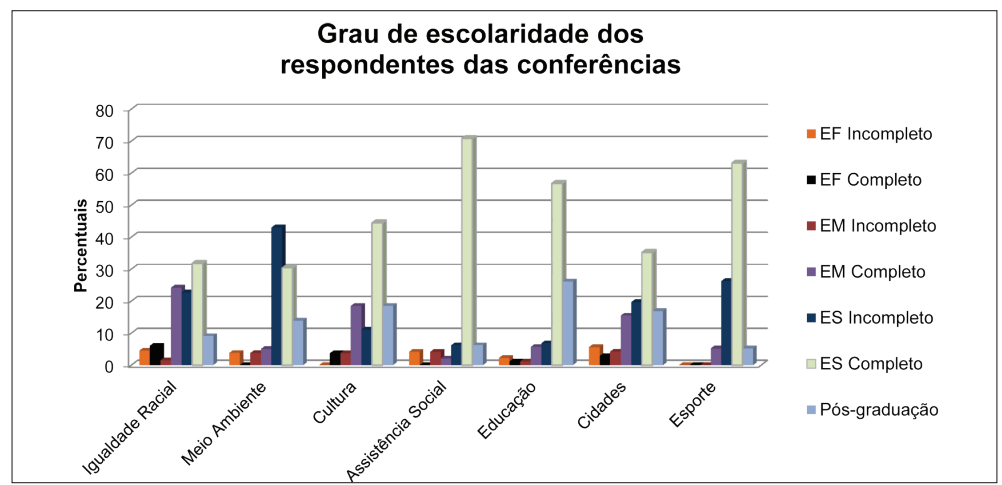

Gráfico 5.4 - Fator escolaridade (em \%)

\section{Faixa salarial dos respondentes nas conferências}
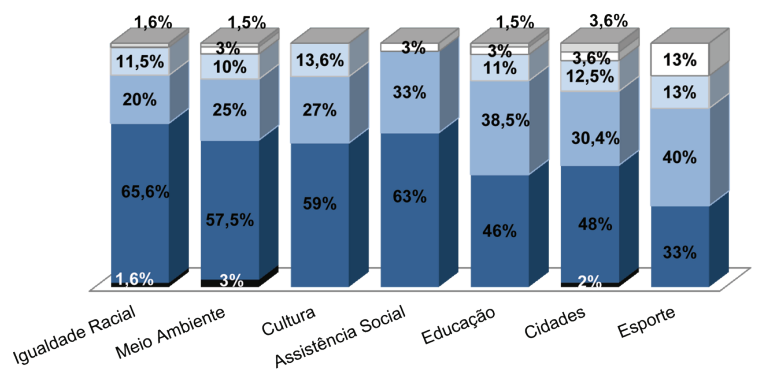

- menos de $\mathrm{R} \$ 1.000$

- $R \$ 1.000$ a $R \$ 4.900$

$\mathrm{R} \$ 5.000$ a $\mathrm{R} \$ 8.900$

$\mathrm{R} \$ 9.000$ a $\mathrm{R} \$ 12.900$

Gráfico 5.5 - Fator renda (em \%)

Em relação ao Gráfico 5.5, observa-se que a população que ganha menos de $\mathrm{R} \$ 1.000,00$ (ou seja, mais ou menos o valor de um 
salário mínimo) não está representada em nenhuma das conferências. Com exceção da conferência do Esporte (em que a maior parte recebe entre $\mathrm{R} \$ 5.000,00$ e $\mathrm{R} \$ 8.900,00)$, todas as outras têm a maioria (ou quase a maioria, como na Educação e Cidades) recebendo entre R\$1.000,00 e R\$4.900,00.

\section{Indicadores de perfil associativo e político}

Com relação a vínculo a ONG/entidade, destaca-se a conferência do Esporte, com 52,6\% de participantes vinculados a alguma entidade, seguida das Cidades, com 44,4\%, e da Igualdade Racial, com 40,9\%. Os participantes da conferência da Educação são os que menos se vinculam às ONGs ou entidades (90,9\%).

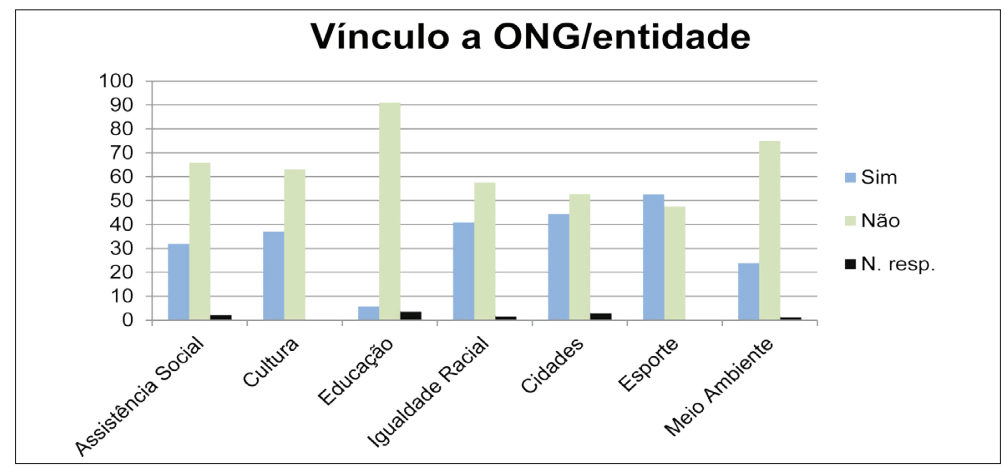

Gráfico 5.6 - Vínculo a ONG/entidade (em \%)

Destaca-se a conferência da Cultura com o maior número de participantes que se declaram vinculados $(59,2 \%)$, seguida das Cidades $(27,8 \%)$ e da Igualdade Racial $(15,1 \%)$. A conferência da Assistência Social não contou com nenhum participante vinculado a movimentos sociais. Com exceção da conferência de Cultura, chama atenção a fraca vinculação a movimentos sociais dos participantes das demais conferências. 


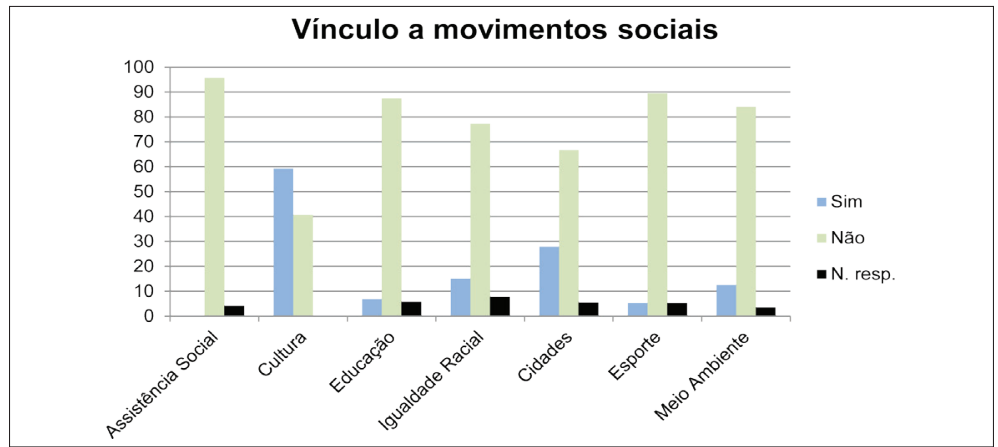

Gráfico 5.7 - Vínculo a movimentos sociais (em \%)

A maior quantidade de participantes filiados a partidos está na conferência do Esporte com 36,9\%, seguida das Cidades, com $34,7 \%$, Igualdade Racial, com 30,3\%, e Cultura com 11,1\%, tendo as demais cerca de $2 \%$ de filiação. Dos filiados, a maioria está no PSDB: Esportes, 15,8\% no PSDB e 5,3\% no PT; Igualdade Racial, 10,6\% no PSDB e 6,1\% no PT; e Cidade tem os mesmos 9,7\% no PSDB e no PT; Cultura tem 7,4\% no PSDB e nenhum filiado ao PT. Outras siglas que aparecem com uma média de 5\% de filiados é o PV (Cidades e Esporte) e o PDT (Esporte). As demais siglas mostram índices menores que $5 \%$.

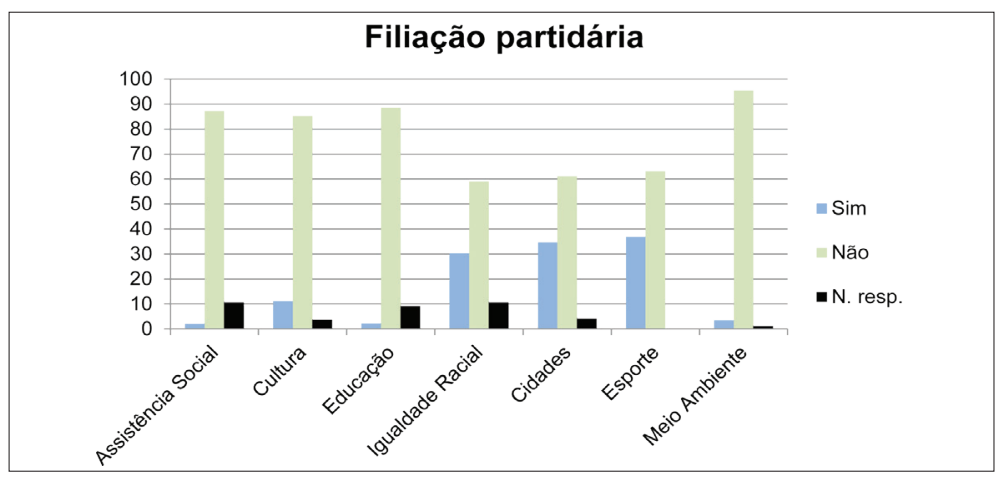

Gráfico 5.8 - Filiação partidária (em \%) 
A grande maioria dos participantes de cinco conferências não é sindicalizada. Nas conferências da Igualdade Racial e das Cidades há uma média de $50 \%$ dos participantes sindicalizados. Dos sindicalizados, $11,1 \%$ se apresentam como dirigentes de sindicatos na conferência das Cidades e 7,6\% na conferência da Igualdade Racial.

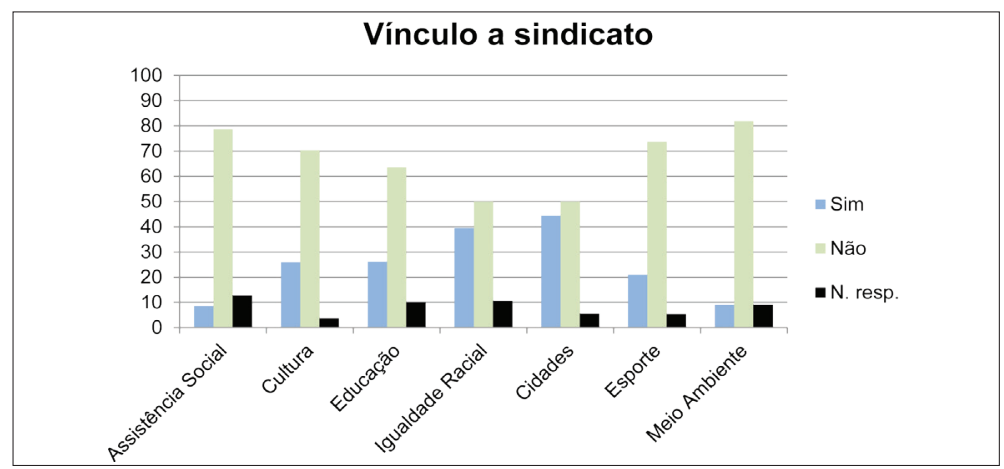

Gráfico 5.9 - Vínculo a sindicato (em \%)

\section{Breves considerações}

Os resultados apresentados sobre as conferências em Piracicaba não permitem inferir generalizações para as áreas de políticas públicas representadas. Conjunturas do momento - referentes à organização de cada conferência, ao contexto do município (do estado e do país) ou ainda às conjunturas de cada área de política pública - permitiram que dado conjunto de participantes estivesse presente naquele momento. Dito de outra forma, os resultados aqui apresentados não são conclusivos. Somente pesquisas continuadas nas áreas estudadas poderiam permitir conclusões mais gerais. Fica, no entanto, a indicação da importância em se considerar a heterogeneidade dos setores de políticas públicas e sua relação com a heterogeneidade dos participantes das conferências relativas a cada setor, em seu perfil socioeconômico e político-institucional. 


\section{De Olho no Legislativo ${ }^{4}$}

O projeto De Olho no Legislativo visou à produção de informação objetiva e avaliativa dos mandatos dos legisladores municipais a fim de proporcionar aos munícipes uma ferramenta de monitoramento da eficiência das ações dos legisladores municipais, contribuindo também para uma maior participação social na vida política do município, além de nortear as medidas possíveis para melhoria das políticas públicas em face dos problemas identificados no desenvolvimento da pesquisa.

Neste capítulo, teve-se a preocupação de mostrar os passos metodológicos para a realização da pesquisa e os problemas encontrados, mas foram omitidas as tabelas com os nomes e notas, bem como o ranking final dos vereadores de Piracicaba, deixando para o Observatório a tarefa de divulgar os resultados, conforme julgar conveniente.

A pesquisa quantitativa utilizou como método a obra organizada por Humberto Dantas (2013), De olho no Legislativo: um método para acompanhar mandatos parlamentares. Essa cartilha traz uma série de critérios que são as competências dos legisladores, estabelecendo outra série de indicadores usados para o levantamento dos dados e para o cálculo da nota. Além dos indicadores, a cartilha estabelece as regras para os pesos que cada competência terá e as regras para o cálculo das notas.

Os materiais utilizados foram de caráter documental, como atas das sessões legislativas, projetos de lei, projetos de resolução, entre outros documentos pertinentes aos trabalhos legislativos, disponíveis no site da Câmara Municipal de Piracicaba (no espaço proposituras e atas).

De acordo com a cartilha, o primeiro passo para a avaliação dos vereadores é estabelecer quais indicadores representam da melhor

4. Participaram ativamente da coleta e tratamento de dados, bem como da elaboração e redação do relatório final os alunos bolsistas do projeto: Beatriz Rennó Biscalchim, Quincas Domingues de Paula e Lucas Marcelino dos Santos. 
forma as percepções da realidade da cidade. Assim, foram selecionadas quatro competências e entre elas sete indicadores. A primeira competência é a atuação como legislador, isto é, a competência da produção de leis e o comparecimento às sessões do Parlamento, que é uma obrigação constitucional do parlamentar e, como tal, deve constar da avaliação. Os indicadores dessa categoria foram: a) total de projetos de impacto, abrangendo todos os projetos de lei, projetos de lei complementar, projetos de decretos, projetos de resolução e propostas de emenda à Lei Orgânica do Município (LOM); b) total de projetos de impacto sancionados, abrangendo também todos os projetos de lei, projetos de lei complementar, projetos de decretos, projetos de resolução e propostas de emenda à LOM que se tornaram lei; c) presença em sessões ordinárias e extraordinárias. Estes últimos são de extrema importância, pois as sessões representam espaços essenciais para a apreciação pública dos debates sobre os projetos de lei em pauta e para o aprofundamento das discussões sobre a viabilidade dos projetos. Aqui apenas foram consideradas as reuniões ordinárias e extraordinárias, sendo que as sessões secretas não foram consideradas, por não constarem como critério da cartilha.

No caso de projetos de impacto foram descartadas as seguintes iniciativas: a) denominação de logradouros (nomes de ruas, avenidas, praças etc.); b) instituição de datas comemorativas; e c) distribuição de honrarias (título de cidadão, chave da cidade, salvas de prata etc.), por esses não apresentarem alterações relevantes na vida social dos cidadãos. Além disso, com vistas ao respeito à objetividade, estamos descartando avaliações do tipo: projeto X é melhor que Y, ou seja, avaliações por critérios subjetivos.

A segunda competência foi a atuação como fiscalizador, que também é uma obrigação constitucional do legislador. A fiscalização depende de um conjunto de gestos associados ao levantamento de dados e convocação de membros do Poder Executivo para a realização de um olhar mais aprofundado sobre suas atividades. Em outras palavras, o papel de fiscalizador resume-se a duas principais frentes de atuação: o olhar sobre o Poder Executivo para 
supervisionar a execução de suas competências mediante a observação das legislações e a atenção para a execução do orçamento. Assim, os indicadores escolhidos dessa categoria foram: a) total de pedidos de informação ao Poder Executivo e b) total de convocações a membros do Executivo. Essa é a forma de o parlamentar demonstrar interesse em matérias do Poder Executivo.

A terceira competência foi a transparência do parlamentar. Trata-se de saber em que medida o parlamentar, como representante político, dá visibilidade para suas ações, bem como de saber quais representantes efetivamente estão dispostos a manter contato com a sociedade. Estar presente a uma arena de debate mais livre é sinal de transparência e desejo de proximidade com os cidadãos. $\mathrm{O}$ indicador escolhido dessa categoria foi presença em audiências públicas.

A quarta e última competência foi a coerência. Há critérios para essa competência não quantificáveis, como a plataforma e as promessas de campanha. Porém, a única prerrogativa legal para esse critério é a fidelidade partidária. Como, de acordo com o sistema eleitoral brasileiro, poucos são os políticos eleitos em pleitos proporcionais que conquistam suas vagas com votação própria, parece pertinente cobrar do representante que permaneça no grupo que o elegeu. Além, é claro, de cobrar que permaneça no grupo ao qual aderiu (ou pelo menos deveria ter aderido) por compartilhamento ideológico. Assim, o indicador escolhido foi fidelidade partidária, para saber quais vereadores permaneceram em seus partidos durante seus mandatos.

A fim de manter o critério de objetividade, não foi considerada a troca partidária com justa causa, conforme prevê a legislação de fidelidade partidária no $1^{\circ}$ ㅇo art. 1ํ da Resolução-TSE n.22.610/2007: "considera-se justa causa a incorporação ou fusão do partido, a criação de novo partido, a mudança substancial ou o desvio reiterado do programa partidário e a grave discriminação pessoal". ${ }^{5}$

5. Disponível em: <http://www.tse.jus.br/partidos/fidelidade-partidaria>. Acesso em: 25 ago. 2013. 
Depois de estabelecidos os indicadores, o passo seguinte foi estabelecer os pesos de cada competência para o cálculo posterior das notas finais. Os pesos foram atribuídos com base na cartilha $D e$ olho no Legislativo, de Dantas (2013), e discutidos em reuniões com a diretoria executiva do Observatório Cidadão de Piracicaba. Após todas as discussões sobre a melhor divisão, ficou decidido o seguinte: a competência legislador possui $40 \%$ de peso, divididos em $15 \%$ para o total de projetos de impacto proposto, $10 \%$ de projetos de impacto sancionados e $15 \%$ para presença nas sessões. A competência fiscalizador possui $40 \%$ do peso divididos em $20 \%$ para pedidos de informação ao Executivo e 20\% para total de convocações aos membros do Executivo. A competência transparência possui $10 \%$ de peso, e a última competência, coerência, possui 10\% do peso, totalizando $100 \%$.

As notas de cada indicador foram calculadas da seguinte maneira: a contagem se dará por parlamentar, ou seja, àquele que obtiver o maior número em cada variável será atribuída nota 10 (dez) e todas as demais notas serão dadas com base nesse resultado de maneira proporcional. Dessa forma, por exemplo, a fórmula dos indicadores ficaria da seguinte maneira:

\section{total dos projetos do parlamentar /}

melhor ou maior resultado apresentado por um vereador $\times 10$

Apenas nos indicadores presença nas sessões ordinárias e extraordinárias e presença nas audiências públicas esse cálculo muda, pois, consideramos o total de sessões e audiências e não o vereador que compareceu no maior número delas, ou seja, o vereador com melhor desempenho:

votações das quais o parlamentar participou / total de votações ou sessões $\times 10$

No indicador fidelidade partidária a atribuição da nota se dá da seguinte forma: o vereador que permaneceu no partido que o elegeu 
recebe nota 10 (dez) e aquele que mudou de partido recebe nota 0 (zero). Esta é a composição da nota para cada critério. A nota final de cada vereador é multiplicada pelo peso do indicador e dividida por 100, para perfazer os $100 \%$ dos pesos.

Em um primeiro momento foi selecionado também, na competência legislador, o indicador total de projetos propostos, que se remete a todos os projetos de lei de autoria do vereador, incluindo os projetos de lei complementar, projeto de decreto, projeto de resolução e proposta de emenda à LOM, como indicador da totalidade da produção legislativa de cada vereador nos anos de 2013 e 2014.

Contudo, em reuniões com a diretoria executiva do Observatório Cidadão de Piracicaba, decidiu-se excluir esse indicador do computo da nota final e disponibilizá-lo apenas como informativo para os munícipes, pois, conforme a cartilha, somente seriam escolhidos dois entre os três indicadores (total de projetos propostos, total de projetos de impacto e total de projetos de impacto sancionados) e os indicadores selecionados foram entendidos como melhores para se considerar na avaliação do desempenho dos vereadores.

Além do indicador informativo, foram excluídas duas outras competências: a) presença em comissões e b) volume de recursos executados em virtude de emenda do legislador ao orçamento do Executivo, pois no primeiro ano do mandato o orçamento em execução fora votado e/ou emendado pelos vereadores do mandato anterior.

$\mathrm{O}$ indicador presença em comissões foi excluído porque as reuniões das comissões ocorrem durante as sessões e não é possível controle independente da presença. Através de contatos estabelecidos com funcionários da Câmara dos Vereadores de Piracicaba, fomos informados que as comissões seguem o artigo 73 , §2ำ do regimento interno da Câmara, que afirma:

Desde que não haja qualquer inconveniência ou tumulto, as Comissões poderão deliberar sobre matérias de sua competência 
no transcorrer das Reuniões Ordinárias, adotando-se o critério da informalidade com vistas à celeridade no trâmite das proposições. Sendo assim, as Comissões de mérito vêm adotando este dispositivo e seus membros deliberam e analisam proposituras durante as Reuniões Ordinárias.

Entendendo o papel da comissão como de um espaço substancial de aprofundamento da análise e debate sobre as matérias propostas nos projetos de lei apresentados, as comissões deveriam ter mais relevância e seus trabalhos deveriam correr em separado ao das sessões ordinárias e extraordinárias. Assim, seria possível saber e controlar a participação efetiva dos vereadores nas comissões.

É importante ressaltar que houve uma alteração na definição dos pesos com relação ao proposto pela cartilha, por definição dos dirigentes do Observatório Cidadão de Piracicaba, que fizeram uma adaptação respeitando as especificidades do município, bem como seus objetivos. Assim, aumentou-se para dois os critérios para a competência legislador (total de projetos de impactos propostos e total de projetos sancionados) - pela cartilha, seria escolhido apenas um critério - e o peso da competência transparência é menor que o da cartilha, que indica no mínimo $20 \%$ de peso.

O método seguido diz que não devem entrar na avaliação o presidente da Câmara, por ter outras atribuições que possam impossibilitá-lo de realizar com assiduidade os pressupostos centrais de seu ofício, e os vereadores que se afastarem dos trabalhos, bem como seus suplentes, pelo motivo de desigualdade na comparação com os demais. Contudo, durante o levantamento dos dados, optamos por incluir os dados do presidente e do(s) vereador(es) que assumiu(assumiram) o mandato, mas que saiu(saíram) de licença, a fim de contemplarmos, mesmo com informação relativa, a totalidade dos legisladores. Dessa forma, colocamos a escolha de utilização desta ou daquela informação a critério do Observatório.

Depois de estabelecidos os indicadores e pesos, e como seria feito o cálculo das notas, foi preciso quantificar as variáveis. Todos 
os dados foram levantados no site da Câmara de Vereadores de Piracicaba, disponíveis pelo espaço proposituras. Por meio das atas das reuniões foram averiguadas as presenças nas sessões ordinárias e extraordinárias e nas audiências públicas.

Por se tratar de uma pesquisa que envolve inúmeros interesses, teve-se também o cuidado de criar um banco de dados com todas as informações levantadas, ou seja, nossa pesquisa também pode ser auditada (conferir Anexo 1).

\section{Breves considerações}

O projeto encontrou algumas dificuldades. Por exemplo, foram selecionados dois indicadores (presença em comissões e volume de recursos executados), mas em virtude de emenda do legislador ao orçamento do Executivo, tais indicadores não puderam ser avaliados, conforme já explicado anteriormente. Ademais, houve problemas com relação ao acesso a algumas informações, mas que foram sanados após contato via correio eletrônico com a administração da Câmara.

Outra dificuldade observada foi com relação a filtros de pesquisa no site. As opções de filtro são confusas e não há instrução para o entendimento sobre o funcionamento preciso dos filtros disponíveis e do próprio sistema de busca. O site disponibiliza um manual sobre a navegação, mas este não contém todas as informações necessárias. Não se consegue, por exemplo, filtrar os projetos de lei sancionados por vereador, ou seja, não há uma opção no filtro com a situação Sancionados.

Apesar das dificuldades, o projeto conseguiu apontar algumas conclusões importantes. Entre as atribuições de um vereador, considerou que a principal delas é a capacidade de legislar, ou seja, de propor projetos de leis que alterarão positivamente a qualidade de vida dos cidadãos. Nesse sentido, as conclusões são insatisfatórias, pois aferimos que nem todos os vereadores apresentam projetos relevantes e na soma dos projetos de impacto protocolados 
pelos vereadores em 2013 - total de 172 - apenas 54 foram aprovados, e em 2014 o número de projetos de impacto proposto caiu para 138, sendo que destes apenas 19 foram sancionados, ou seja, um número quase três vezes menor em comparação com 2013. O volume maior de proposições vem de projetos que se resumem a denominação de logradouros, instituição de datas comemorativas e distribuição de honrarias.

Da segunda competência mais importante dos vereadores, fiscalizar o Poder Executivo, constatou-se que poucos deles protocolam pedidos de informação ao chefe do Executivo ou fazem convocações para prestação de esclarecimentos. Alguns vereadores chegam a ter nenhum pedido de informação ao chefe do Poder Executivo, situação que se repete com os pedidos de convocação aos membros do Executivo. Em média, nos dois anos avaliados, os vereadores compareceram razoavelmente às sessões ordinárias e extraordinárias, embora o maior índice de falta seja nas sessões extraordinárias. Já analisando as presenças em audiências públicas, constatou-se uma grave falta quanto à atuação dos vereadores em 2013: 7 dos 23 vereadores de Piracicaba não compareceram a nenhuma audiência pública. Em 2014, esse número caiu para 5 vereadores. Em 2013, apenas 1 vereador compareceu às 8 audiências públicas, e em 2014, nenhum vereador compareceu às 7 audiências públicas realizadas em Piracicaba. ${ }^{6}$

Analisando as notas dos vereadores, a partir dos critérios estabelecidos, observa-se um baixo desempenho deles como representantes do Legislativo piracicabano. Em 2013, apenas 6 vereadores obtiveram notas maiores que 5 , sendo que a maior nota no mesmo ano foi 6,71, ou seja, nenhum vereador em 2013 recebeu nota maior ou igual a 7 pelo seu desempenho. Em 2014, a mudança nesse quadro foi quase insignificante: apenas 7 vereadores apresentaram

6. Esses dados podem indicar quais vereadores têm maior disposição em manter aproximação com os cidadãos que os elegeram; daí a importância de se comparecer às audiências públicas. 
notas maiores que 5, e a maior nota atribuída pelo desempenho do vereador foi 7,34.

Pode-se dizer que o resultado obtido nesse projeto foi a produção de uma lista classificatória dos vereadores baseada em avaliação objetiva dos mandatos dos legisladores municipais cumprindo com o propósito de proporcionar aos munícipes uma ferramenta de monitoramento da eficiência das ações dos legisladores, contribuindo também para uma maior participação social na vida política do município. Esperamos que esta avaliação possa servir para estimular novos comportamentos no desempenho das funções dos representantes do Legislativo de Piracicaba, quiçá de outros municípios brasileiros, no sentido de contribuir para o dinâmico processo de construção e consolidação da nossa democracia.

\section{Considerações finais}

Com relação à pesquisa sobre as conferências de Piracicaba, além dos resultados obtidos e disponibilizados para o Observatório, a pesquisa foi apresentada no IX Congresso Internacional da Associação Brasileira de Ciência Política. No caso do projeto De Olho no Legislativo, além da produção dos resultados disponibilizados para o Observatório, o projeto foi apresentado no XXVI Congresso de Iniciação Científica da Unesp, sendo classificado em primeiro lugar para a segunda fase na área de Administração Pública, dentre os muitos trabalhos que concorreram. Também foi apresentado no Mostre Unesp, promovido pelo Instituto de Química da Unesp de Araraquara. Essas apresentações em espaços acadêmicos permitiram divulgar tanto o importante trabalho desenvolvido pelo Observatório Cidadão de Piracicaba como o alcance dos projetos de extensão promovidos pela Unesp.

Reafirmamos, assim, a importância de dar continuidade a este projeto de extensão reforçando seus objetivos: a) contribuir, a partir da expertise da academia, com o Observatório avançando na pesquisa sobre as várias áreas de políticas públicas e suas dinâmicas 
com relação aos espaços de participação; b) fornecer dados sobre as instituições participativas com o objetivo de diagnosticar limites e problemas, apontando soluções para potencializá-las como espaços inovadores da democracia brasileira; c) contribuir com o Observatório na coleta de dados primários que possam ser acessíveis à população do município; d) contribuir com a coleta de dados que possam ser utilizados pelo poder público municipal, Executivo e Legislativo, com vistas à melhoria de sua atuação diante das demandas da população.

Esse trabalho também possibilita a formação continuada aos alunos a partir da experiência com coleta e tratamento de dados, observação participante, escrita de relatórios e, fundamentalmente, possibilitar a todos os envolvidos no projeto de extensão - docentes e discentes - uma oportunidade de avançar no conhecimento de realidades específicas e de influenciá-las, como cidadãos ativos, em um dinâmico exercício de aprimoramento da nossa democracia.

\section{Referências bibliográficas}

CÂMARA DE VEREADORES DE PIRACICABA. Disponível em: <http://transparencia.camarapiracicaba.sp.gov.br/legislacao /proposituras>. Acesso em: 25 jun. 2014.

DANTAS, H. (Org.). De Olho no Legislativo: um método para acompanhar mandatos parlamentares. Rio de Janeiro: Fundação Konrad Adenauer, 2013. Disponível em: <http://www.votoconsciente. org.br/wp-content/uploads/2013/02/LIVRO-FINAL-_-MVC-KAS.pdf>. Acesso em: 25 ago. 2013.

ROMÃO, W. M. et al. Os Observatórios Cidadãos no fortalecimento da democracia e do accountability no Brasil: o caso do Observatório Cidadão de Piracicaba. International Research Society for Public Management Conference, Ottawa, Canadá, 2014 (versão em português). 


\section{Anexo 1}

\section{A) Para total de projetos propostos}

1. Abrir o link <http://transparencia.camarapiracicaba.sp.gov.br/ legislacao/proposituras $>$.

2. Na ferramenta de busca selecionam-se os itens: projeto de lei, projeto de lei complementar, projeto de decreto, projeto de resolução e projeto de emenda à LOM.

3. Seleciona-se o ano de interesse.

4. Seleciona-se a situação: TODAS.

5. Seleciona-se a autoria: o vereador.

6. Clicar em CONSULTAR.

7. Foram selecionados todos os projetos propostos independente de serem de impacto.

B) Para os projetos de impacto propostos

1. Abrir o link <http://transparencia.camarapiracicaba.sp.gov.br/ legislacao/proposituras $>$.

2. Na ferramenta de busca selecionam-se os itens: projeto de lei, projeto de lei complementar, projeto de decreto, projeto de resolução e projeto de emenda à LOM.

3. Seleciona-se o ano de interesse.

4. Seleciona-se a situação: TODAS.

5. Seleciona-se a autoria: o vereador.

6. Clicar em CONSULTAR.

7. Faz-se a leitura e seleção dos projetos conforme critérios estabelecidos.

C) Para os projetos de impacto sancionados

1. Abrir o link <http://transparencia.camarapiracicaba.sp.gov.br/ legislacao/proposituras $>$.

2. Na ferramenta de busca selecionam-se os itens: projeto de lei, projeto de lei complementar, projeto de decreto, projeto de resolução e projeto de emenda à LOM. 
3. Seleciona-se o ano de interesse.

4. Seleciona-se a situação: TODAS.

5. Seleciona-se a autoria: o vereador.

6. Clicar em CONSULTAR.

7. Faz-se a leitura dos projetos de impacto selecionados no item anterior e selecionam-se apenas os projetos de impacto que foram sancionados.

D) Presença nas sessões ordinárias, extraordinárias e audiências públicas

1. Abrir o link <http://transparencia.camarapiracicaba.sp.gov.br/ legislacao/atas $>$.

2. Selecionar o ano de interesse e fazer o download das atas para verificar as presenças.

E) Pedidos e convocações a membros do Executivo

1. Abrir o link <http://transparencia.camarapiracicaba.sp.gov.br/ legislacao/proposituras $>$.

2. Na ferramenta de busca seleciona-se o item requerimento.

3. Seleciona-se o ano de interesse.

4. Seleciona-se a autoria: o vereador.

5. Clicar em CONSULTAR.

6. Selecionar os pedidos de solicitação de informação ao chefe do Executivo, e as convocações a membros do Poder Executivo.

\section{F) Fidelidade partidária}

1. Abrir o link <http://www.camarapiracicaba.sp.gov.br/>.

2. Clicar na figura do vereador de interesse.

3. Clicar em PERFIL. 


\title{
6 \\ UNESP NOS MUNICÍPIOS: APOIO AO DESENVOLVIMENTO ECONÔMICO DOS MUNICÍPIOS DA ÁREA DE INFLUÊNCIA DA FCLAR
}

\author{
Cláudio Cesar de Paiva \\ Suzana Cristina Fernandes de Paiva
}

\section{Introdução}

A Universidade poderia ser definida como sendo, grosso modo, uma síntese da indissociabilidade entre ensino, pesquisa e extensão. Trata-se de três processos correlatos, que articulam com certa organicidade os processos de construção do saber, de transmissão e apropriação do saber historicamente sistematizado e da materialização desses conhecimentos na transformação da sociedade. Esse tripé seria responsável por conduzir movimentos analíticos sincrônicos e diacrônicos para a compreensão das mudanças na relação Universidade-sociedade e para a articulação de novas relações transformadoras com a sociedade.

Assim, como aponta a Política Nacional de Extensão Universitária, a Universidade, como instância produtora do conhecimento, deve ser capaz de oferecer aos governos e à sociedade as tecnologias, as teorias e os processos, assim como os profissionais capazes de propulsionar o desenvolvimento, e, para que isso não se restrinja à esfera econômica, seja sustentável e tenha um caráter ético, é pre- 
ciso que esses "produtos" estejam afinados com os valores e interesses sociais.

$\mathrm{Na}$ prática, entretanto, observa-se que o tripé (ensino-pesquisa-extensão) é manco em várias universidades brasileiras, especialmente em relação à extensão, em decorrência de pelo menos dois aspectos: a) reduzido reconhecimento de mérito nas atividades extensionistas, particularmente quando comparado aos pesquisadores stricto sensu; b) desconhecimento do que é extensão universitária pelos próprios extensionistas, já que muitos dos programas, projetos e ações são voltados prioritariamente para o público interno, quando o público externo à universidade deveria, por definição, ser o foco.

A ausência de público externo em muitas atividades extensionistas, algo que soa estranho e incoerente, se mostra uma situação bastante recorrente, o que suscita reflexões importantes. A pesquisa levada além dos muros da Universidade, por meio das atividades extensionistas, reflete, de fato, as demandas da sociedade? Estariam afinadas com os valores e interesses sociais?

Para isso, é necessário esclarecer a definição de extensão universitária. De acordo com a Política Nacional de Extensão Universitária, da qual a Unesp é signatária, a extensão universitária é definida da seguinte forma:

A Extensão Universitária, sob o princípio constitucional da indissociabilidade entre ensino, pesquisa e extensão, é um processo interdisciplinar, educativo, cultural, científico e político que promove a interação transformadora entre Universidade e outros setores da sociedade. (Forproex, 2012, p.15)

O projeto em tela se insere no âmbito das deliberações estabelecidas pelo Forproex para uma ação política, especificamente para o incremento da articulação das ações extensionistas com as políticas públicas. Nesse sentido, assume-se que os efeitos positivos almejados da articulação da extensão universitária com as políticas públicas podem advir de uma contribuição direta dos atores acadê- 
micos na formulação, implementação e avaliação dessas políticas, bem como da contribuição para a superação da fragmentação, setorialização, desarticulação e superposição de programas e projetos sociais, bem como do caráter, muitas vezes residual e temporário.

Não perdendo de vista essa quadra introdutória, nas próximas seções serão discutidas a natureza, as características e os objetivos almejados com o projeto Unesp nos Municípios: Apoio ao Desenvolvimento Econômico dos Municípios da Área de Influência da FCLAr, bem como estabelecer a relação do projeto com as diretrizes da Política Nacional de Extensão Universitária, de 2012.

\section{Construindo a proposta de uma ação extensionista: cenário, características e objeto}

A Unesp apresenta características peculiares em relação às demais universidades estaduais paulistas, particularmente no que se refere à sua distribuição geográfica com vários câmpus e à formação de profissionais com capacidade de gerar e disseminar conhecimento especializado por todo interior do estado de São Paulo.

Esses diferenciais imputaram à Unesp papel fundamental no dinamismo econômico das cidades e regiões em que seus câmpus estão instalados. Essa responsabilidade foi assumida pela Universidade no momento da elaboração do Plano de Desenvolvimento Institucional (PDI), quando torna explícita na sua missão, na visão de futuro e nas ações estratégicas da extensão universitária o compromisso indelével com o desenvolvimento sustentável e com a redução das iniquidades históricas de nossa sociedade.

Nessa perspectiva, enfatiza com contundência a missão de "gerar, difundir e fomentar o conhecimento, contribuindo para a superação de desigualdades e para o exercício pleno da cidadania”. Ao exercer a atividade de extensão, promove o próprio ensino e valida a pesquisa, respeitando os princípios de indissociabilidade entre ensino, pesquisa e extensão (já citados anteriormente), nos termos amplamente institucionalizados pela Constituição Federal 
de 1988 (art. 207), pela Lei de Diretrizes e Bases da Educação Nacional (LDB) (Lei n.9.394), de 1996, pelo Plano Nacional de Educação, para o decênio 2001-2010 (PNE 2001-2010) (Lei n.10.172) e pela Política Nacional de Extensão Universitária, aprovado pelo Forproex, em 2012.

No caso da FCLAr/Unesp, as informações sobre projetos e ações extensionistas apontam para uma participação da instituição nos municípios muito aquém do potencial de conhecimento produzido pelos seus docentes e da demanda declarada pelos municípios.

Diante desse quadro e visando contribuir com as administrações públicas municipais no aperfeiçoamento das ações de planejamento de longo prazo e na capacitação dos agentes públicos e sociais, foi apresentado o presente projeto de extensão. O objetivo é promover uma aproximação entre o conhecimento produzido e sistematizado pela Unesp, particularmente no âmbito dos cursos de Economia e de Administração Pública, e os municípios da região de influência da FCLAr.

Assim posto, deve ser realçado que a ação contundente da Unesp, por meio da geração de subsídios para as atividades de planejamento e formulação de políticas públicas nos municípios, contribui sobremaneira para assegurar maior eficiência, economicidade, eficácia e efetividade na construção e gestão das políticas públicas locais.

A disseminação do conhecimento produzido na FCLAr/Unesp pode ser realizada por meio de palestras e cursos, com conteúdos científicos adequadamente apropriados por gestores públicos, vinculados ao Executivo e ao Legislativo municipal, e a comunidade em geral. O projeto busca intermediar demandas dos municípios com as expertises dos docentes do curso de Administração Pública e Economia.

O projeto é executado em duas fases complementares. A primeira corresponde à fase de diagnóstico socioeconômico, pela sistematização de informações sociais e econômicas e da construção de indicadores que se encontram disponibilizadas em diversas bases de dados: censo demográfico, Pesquisa de Informações Básicas 
Municipais (Munic), Tesouro Nacional, Pesquisa Nacional por Amostra de Domicílios (Pnad), Cadastro Geral de Empregados e Desempregados (Caged), Relação Anual das Informações Sociais (Rais), base de dados dos programas de transferência de renda (indicadores de pobreza e indigência), indicadores urbanos e saneamento, déficit habitacional, entre outros. Essa ação permite a construção de um banco de dados, com informações institucionais e indicadores quantitativos e qualitativos em nível municipal que, disponibilizados à comunidade, servirão como base para reflexões sobre os desafios e o futuro desses municípios.

A segunda fase corresponde aos cursos e palestras direcionadas especificamente para atender demandas e/ou a discussão de temáticas relevantes para os municípios que, embora próximos à Unesp, sofrem com a falta de debates e cursos de qualificação dos gestores municipais nas áreas de finanças públicas, planejamento urbano e gestão de políticas públicas em geral.

Cabe ressaltar, conforme apontado pelo Munic 2009, que as dificuldades para a construção de políticas públicas qualificadas e focalizadas constitui um nó górdio da administração pública municipal em todo o país. Muitos municípios não conseguem ter acesso aos recursos disponibilizados pela esfera federal devido à falta de capacitação para apresentar um projeto justificando a necessidade/ demanda por tais recursos.

Os municípios priorizados no atendimento do projeto são aqueles pertencentes a área de influência direta da FCLAr, que corresponderiam aos municípios que compõem a Associação dos Prefeitos da Região Central do Estado de São Paulo (Aprec), composta pelos seguintes municípios: Araraquara, Cândido Rodrigues, Guatapará, Matão, Itápolis, Rincão, Santa Ernestina, Ribeirão Bonito, Borborema, Tabatinga, Américo Brasiliense, Nova Europa, Ibaté, Ibitinga, Santa Lúcia, São Carlos, Gavião Peixoto, Taquaritinga, Motuca, Trabiju e Itirapina.

As informações sobre os municípios que compõem a Aprec, apresentados no Quadro 6.1, permitem verificar certa discrepância em termos dos indicadores de desenvolvimento, como o Índice de 
Desenvolvimento Humano Municipal (IDHM) e do PIB per capita. Ao acrescentar a essas informações os indicadores sociais de cada município, nota-se um agravamento ainda maior da distância e dos padrões de desenvolvimento. Nessa situação, a presença da Unesp contribui sensivelmente para a discussão e a colaboração técnica, particularmente para os pequenos municípios, no sentido de promover as condições para um planejamento de longo prazo e de políticas públicas que resultem numa maior equidade intra e intermunicipal.

Quadro 6.1 - Dados dos municípios que compõem a Aprec

\begin{tabular}{|l|c|r|r|c|}
\hline \multicolumn{1}{|c|}{ Municipios } & $\begin{array}{c}\text { População 2014 } \\
\text { Estimativa } \\
\text { IBGE }\end{array}$ & $\begin{array}{c}\text { IDHM } \\
2010\end{array}$ & \multicolumn{1}{c|}{$\begin{array}{c}\text { PIB } \\
2012\end{array}$} & $\begin{array}{c}\text { PIB per } \\
\text { capita } \\
2012\end{array}$ \\
\hline Américo Brasiliense & 37.691 & 0,751 & 557.896 & $15.754,00$ \\
\hline Araraquara & 224.304 & 0,815 & 5.681 .826 & $26.723,29$ \\
\hline Borborema & 15.454 & 0,730 & 262.331 & $17.808,08$ \\
\hline Cândido Rodrigues & 2.773 & 0,789 & 56.947 & $21.272,60$ \\
\hline Gavião Peixoto & 4.662 & 0,719 & 354.010 & $79.303,21$ \\
\hline Guatapará & 7.394 & 0,743 & 134.324 & $19.036,87$ \\
\hline Ibaté & 33.178 & 0,703 & 401.070 & $12.781,08$ \\
\hline Ibitinga & 57.098 & 0,747 & 942.285 & $17.402,67$ \\
\hline Itápolis & 42.135 & 0,744 & 763.829 & $18.907,13$ \\
\hline Itirapina & 16.938 & 0,724 & 255.161 & $16.017,61$ \\
\hline Matão & 80.990 & 0,773 & 6.194 .929 & $79.887,15$ \\
\hline Motuca & 4.571 & 0,741 & 89.574 & $20.572,85$ \\
\hline Nova Europa & 10.276 & 0,765 & 168.576 & $17.558,20$ \\
\hline Ribeirão Bonito & 12.831 & 0,712 & 177.420 & $14.459,67$ \\
\hline Rincão & 10.782 & 0,734 & 151.762 & $14.554,76$ \\
\hline Santa Ernestina & 5.691 & 0,738 & 60.904 & $10.989,46$ \\
\hline Santa Lúcia & 8.651 & 0,737 & 107.886 & $12.985,78$ \\
\hline São Garlos & 238.958 & 0,805 & 5.769 .745 & $25.493,52$ \\
\hline Tabatinga & 15.738 & 0,704 & 177.166 & $11.856,15$ \\
\hline Taquaritinga & 56.398 & 0,748 & 859.799 & $15.840,35$ \\
\hline Trabiju & 1.650 & 0,722 & 28.350 & $18.068,80$ \\
\hline
\end{tabular}

Fonte: IBGE. 
É importante ressaltar que a população no raio de até $70 \mathrm{~km}$ da FCLAr atinge mais de 1 milhão de habitantes, carentes de ações públicas baseadas em planejamento.

Ao assumirmos a direção da FCLAr, em 2013, procuramos promover a aproximação entre a Unesp e a administração pública local. A ressonância das propostas de cooperação com o Legislativo e com o Executivo foi imediata. No caso do Executivo, ocorreram demandas em quase todas as secretarias, enquanto no Legislativo a incursão gerou uma parceria ainda mais proveitosa. A FCLAr teve uma participação fundamental na constituição, neste primeiro semestre, da Escola do Legislativo de Araraquara, uma experiência bastante exitosa que poderia ser reproduzida em outras unidades.

Essa experiência associada às demandas declaradas de outras prefeituras da região revelam, por um lado, o desconhecimento por parte dos gestores públicos da expertise e das pesquisas produzidas pelos docentes da Unesp e, por outro, uma demanda reprimida bastante expressiva em relação a capacitação de gestores, no sentido de qualificar e aperfeiçoar as ações de planejamento de longo prazo no município. Essas situações são bastante evidentes nos incipientes debates sobre temáticas relevantes para os municípios, como na atual discussão do PPA (2014-2017) e na discussão da Política Nacional de Resíduos Sólidos (PNRS) e seus impactos municipais.

O projeto conta com diversos docentes dos Departamentos de Administração Pública e Economia, participação imprescindível, já que o projeto procura intermediar expertises da FCLAr/Unesp para o atendimento das demandas dos municípios sobre políticas públicas e orçamento. Além disso, é importante observar que o projeto tem como base de apoio físico à sala 36, do prédio de pesquisa (Grupo de Estudos em Economia Financeira, Fiscal, Análise Quantitativa e Desenvolvimento), para que os alunos possam desenvolver a fase de diagnóstico socioeconômico, através da sistematização de informações sociais e econômicas e da construção de indicadores que se encontram disponibilizados em diversas bases de dados. 


\section{Os resultados do projeto}

\section{Resultados gerais esperados}

O projeto de extensão Unesp nos Municípios: Apoio ao Desenvolvimento Econômico dos Municípios da Área de Influência da FCLAr procura responder à demanda de diversos municípios por apoio mais incisiva da Unesp, no sentido de auxiliar os debates e as ações de planejamento das administrações municipais e na capacitação dos agentes públicos e sociais. Trata-se, portanto, de um projeto de fundamental relevância para a consolidação do papel da Universidade na transformação efetiva da realidade econômica e social dos municípios.

A execução desse projeto de extensão permite que as diretrizes estratégicas adquiram certa materialização ao assumir uma participação mais efetiva nos rumos do desenvolvimento dos municípios da região, isto é, para além das contribuições econômicas e financeiras que já realiza.

Para as prefeituras, o projeto representa o acesso ao conhecimento produzido pelos docentes da Unesp, o que garante maior eficiência na alocação de recursos, eficácia e qualidade dos serviços prestados à população, além de proporcionar subsídios para as atividades de planejamento público e formulação de políticas sociais.

Aos professores e alunos (bolsistas e não bolsistas) envolvidos, o projeto é uma forma de inserção crítica e reflexiva, além de possibilidade de interação entre pesquisa e extensão; trata-se de um canal de difusão para a prática do conhecimento produzido, muitas vezes, no campo essencialmente teórico.

Necessariamente, o resultado dessa experiência produz seus efeitos imediatos no pilar-mestre: o ensino. Para o aluno, a experiência serve para o reconhecimento de outros espaços, além da sala de aula, como locais privilegiados de aprendizagem, onde o conhecimento desenvolvido ganha concretude e objetividade. 
Assim posto, a experiência de implantação do projeto gera sinergias e efeitos autoalimentadores de propostas de pesquisa e extensão, com ampliação da qualidade da produção científica e técnica. Esses processos retroalimentadores, decorrentes da extensão universitária, estão em plena aderência com o princípio de que a Universidade não é proprietária de um saber pronto e acabado, mas é da interação com a sociedade que surgem as problemáticas e os desafios acadêmicos.

\section{Indicadores de impactos internos}

Os fatores de impacto interno são diversos, dentre os quais destacam-se: o aprimoramento da formação profissional do aluno de graduação pela aproximação com a realidade dos conteúdos teóricos vistos nos cursos de Administração Pública e Economia; ampliação de espaços formativos e investigativos para alunos de graduação e professores orientadores envolvidos direta ou indiretamente (eventuais participações em cursos e palestras) no projeto; participação da equipe em eventos científicos com apresentação de resultados; debates e palestras que promovam a reflexão crítica dos alunos/professores quanto à bibliografia teórica trabalhada em sala de aula; cursos de qualificação de alunos para trabalhar com bases de dados e microdados; disponibilização de bases de informações sistematizadas que deverão contribuir para elaboração de trabalhos de conclusão de curso.

\section{Indicadores de impactos externos}

Os fatores de impacto externo são os mais expressivos: a Unesp deve se consolidar como referência no debate de políticas públicas e de planejamento regional. Os cursos e debates promovidos nos municípios, bem como os indicadores municipais e regionais contribuem para ampliar os debates nos legislativos municipais, no âmbito da Aprec e na sociedade civil organizada. 
Além disso, o projeto será uma fonte importante de informações regionais para jornais e programas de televisão, ampliando a periodicidade das divulgações pelo Núcleo de Extensão em Conjuntura e Estudos Econômicos (disponível em: <http://www.fclar. unesp.br/\#!/departamentos/economia/necee/>), de que a equipe deste projeto faz parte. Além disso, o projeto estará associado ao Programa Instituto de Direito à Cidade (Proext 2014), da parceria entre UFSCar/FCL-Unesp.

\section{Articulação com ensino e pesquisa}

Como escrito anteriormente, o projeto é uma forma de inserção crítica e reflexiva. Necessariamente, o resultado da experiência produz seus efeitos imediatos no pilar-mestre, que é o ensino. Em suma, o desenvolvimento do projeto implica necessariamente respeitar os princípios de indissociabilidade entre ensino, pesquisa e extensão.

$\mathrm{Na}$ situação em análise, esse projeto de extensão externaliza parte da pesquisa desenvolvida no âmbito do Grupo de Estudos em Economia Financeira, Fiscal, Análise Quantitativa e Desenvolvimento. Além disso, os alunos participantes do projeto são necessariamente dos cursos de Administração Pública e Economia, pois é necessário articular o conhecimento das disciplinas cursadas para propor soluções (políticas públicas) de modo a subsidiar a ação dos agentes públicos e das comunidades sociais.

\section{Importância para a formação do aluno}

$\mathrm{Na}$ construção deste projeto de extensão, o princípio fundamental é que a educação é o elemento central para a transformação social. Sua lógica construtiva está em correlata simetria com Marcovitch (1997), que afirma ser importante que a Universidade trabalhe para que o papel dos estudantes, no futuro, seja o de verdadeiros agentes de mudança; afinal, "a educação é instrumento social, polí- 
tico e econômico não para produzir, de forma isolada, a mudança social, mas para servir de instrumento para que os sujeitos sociais sejam sujeitos do processo de mudança” (Belloni, 2000, p.38).

Nesta perspectiva, o projeto se apresenta como de fundamental importância para a formação dos alunos dos cursos de Administração Pública e Economia. Para os estudantes envolvidos nas discussões, o projeto constitui uma forma de inserção crítica e reflexiva, além de uma possibilidade de interação entre pesquisa e extensão.

\section{Considerações finais}

O objetivo do projeto de extensão é promover uma aproximação entre o conhecimento produzido pela Unesp, particularmente no âmbito dos cursos de Economia e de Administração Pública, e os municípios da região de influência da FCLAr, para contribuir com as administrações públicas municipais no aperfeiçoamento das ações de planejamento de longo prazo e na capacitação dos agentes públicos e sociais.

Para atingir os objetivos propostos pelo projeto de extensão Unesp nos Municípios: Apoio ao Desenvolvimento Econômico dos Municípios da Área de Influência da FCLAr, são necessários recursos de toda natureza - políticos, organizacionais, técnicos, científicos, tecnológicos, econômicos/financeiros, institucionais/ legais -, porém os efeitos positivos das ações são disseminados para a sociedade. Daí a necessidade de uma equipe de professores doutores com atuação multidisciplinar, formada por docentes dos cursos de Economia e Administração Pública: Cláudio Cesar de Paiva, Suzana Cristina Fernandes de Paiva, Elton Eustáquio Casagrande, Fausto Saretta e Sergio Azevedo Fonseca. Além disso, o projeto conta com a participação de um membro externo, da Universidade Federal de São Carlos (UFSCar), prof. dr. Luiz Antonio Nigro Falcoski. 
No primeiro ano de execução do projeto houve uma grande redução dos recursos financeiros disponibilizados pela Pró-Reitoria de Extensão Universitária da Unesp. O corte severo nos recursos financeiros impactou diretamente a execução do projeto, tornando necessário um ajuste nas estratégias previstas. A principal mudança redirecionou o foco das ações para o município-polo do projeto, o que não impediu que, ao longo de 2014, fossem realizadas visitas a alguns municípios do entorno e a realização de várias reuniões com autoridades políticas municipais e deputados, que sinalizavam a relevância de uma parceria com a Unesp, sobretudo para viabilizar o desenvolvimento local/regional.

O projeto tem se pautado invariavelmente por uma agenda de demandas formulada por diversos municípios que necessitam de um apoio mais efetivo da Unesp, particularmente para auxiliar os debates e as ações de planejamento das administrações municipais e na capacitação dos agentes públicos e sociais.

Nesse sentido, a Universidade deve buscar a construção de espaços e processos dialógicos que permitam superar o conflito em direção à cooperação, bem como contribuir com seus conhecimentos para subsidiar, de forma crítica e autônoma, os agentes públicos e a sociedade civil para que a oferta de bens públicos e a formulação das políticas públicas tenham maior efetividade.

\section{Referências bibliográficas}

BELLONI, I. A função social da avaliação institucional. In: DIAS SOBRINHO, J.; RISTOFF, D. L. Universidade desconstruída: avaliação institucional e resistência. Florianópolis: Insular, 2000.

FONSECA, S. A.; DE LORENZO, H. C. Breve perfil das atividades de extensão nas unidades da Unesp, câmpus de Araraquara: um enfoque na transferência de tecnologia e conhecimento. Revista Ciência em Extensão, v.1, n.2, p.112-29, 2004.

FÓRUM DE PRÓ-REITORES DE EXTENSÃO DAS UNIVERSIDADES PÚBLICAS BRASILEIRAS (Forproex). Plano Na- 
cional de Extensão Universitária. Manaus, 2012. Disponível em: $<$ http://www.renex.org.br/documentos/2012-07-13-Politica -Nacional-de-Extensao.pdf>. Acesso: 11 jan. 2015.

UNESP. Plano de Desenvolvimento Institucional. São Paulo: Unesp, 2009. 


\title{
7 \\ HeRÓIS PARA UM FUTURO SUSTENTÁVEL
}

\author{
Patricia Borba Marchetto \\ Djalma Roberto Larocca Junior \\ Ariovaldo de Oliveira Filho \\ Ana Claudia Fernandes Terence \\ Jorge Henrique de Oliveira Silva \\ David Teixeira Pinto
}

\section{Apresentação}

O presente capítulo é o resultado das atividades de pesquisa e extensão universitária realizadas por professores e alunos do curso de Administração Pública da Faculdade de Ciências e Letras de Araraquara (FCLAr/Unesp), desenvolvidas junto ao Projeto AdministrAÇÕES, cadastrado no Programa de Integração da Extensão Universitária com o Ensino e a Pesquisa na Proex/Unesp desde 2010. O projeto, desenvolvido em parceria com a Cooperativa Acácia de Catadores de Materiais Recicláveis de Araraquara-SP, integra uma perspectiva transdisciplinar envolvendo temáticas como meio ambiente, direitos humanos e política, tendo como objetivos aprofundar os conhecimentos já adquiridos, à luz de experiências concretas decorrentes de seu desenvolvimento, propiciar uma oportunidade de articulação entre os conceitos e as técnicas apreendidas pelos alunos, com a prática administrativa desenvolvida em organizações ou instituições públicas (governamentais ou não) e oferecer uma visão global da instituição pública como complemento prático da formação dos estudantes. 
Por questões didáticas, primeiramente, será exposto brevemente o contexto sociopolítico no qual se insere a organização em questão, seguido de um histórico da Cooperativa Acácia. No segundo momento, será apresentado o desenvolvimento do Projeto AdministrAÇÕES, em todos os seus eixos de atuação, com destaque especial aos resultados alcançados no eixo "Heróis para um futuro sustentável”.

\section{Introdução}

\section{Estado de crise}

O atual modelo de desenvolvimento econômico produziu uma crise com consequências extremamente negativas de ordens ambiental e social, bem como um ônus pesado aos estados e às sociedades. Sobre esse tema, importantes pensadores dos séculos XX e XXI pronunciaram-se de forma bastante assertiva. Jacques Ellul (1968) apresenta esse estado de crise como uma das consequências do fenômeno da técnica - acelerado a partir da Revolução Industrial e caracterizador do que ele denominou Sociedade Técnica. O conceito descreve uma sociedade humana servil à técnica, orientada única e exclusivamente por valores técnicos, e, consequentemente, distante e não consciente do seu permanente estado crítico, que envolve problemas associados a questões ambientais e sociais complexas.

Fritjof Capra, em $O$ ponto de mutação, afirma que

As duas últimas décadas de nosso século vêm registrando um estado de profunda crise mundial. É uma crise complexa, multidimensional, cujas facetas afetam todos os aspectos da nossa vida - a saúde e o modo de vida, a qualidade do meio ambiente e das relações sociais, da economia, tecnologia e política. É uma crise de dimensões intelectuais, morais e espirituais; uma crise de escala e premência sem precedentes em toda a história da humanidade. 
Pela primeira vez, temos que nos defrontar com a real ameaça de extinção da raça humana e de toda a vida no planeta. (1995, p.19)

Sobre esse estado de crise, outro importante pensador da sociedade contemporânea, Edgar Morin, discorre: "é uma crise de civilização que se estende e se aprofunda surdamente pelo desenvolvimento de males produzidos pelo avesso da individualização, pelo avesso da tecnicização, pelo avesso da monetarização, pelo avesso do crescimento" (1996, p.4).

Marchetto entende que "vivemos hoje em um contexto marcado ao extremo por relações de consumo. Os elevados índices de violência e o absoluto descrédito à espécie humana nos faz crer que enfrentamos, já há algum tempo, uma verdadeira crise de valores" (2009, p.2).

\section{Dimensão ambiental da crise}

Em sua dimensão ambiental, é possível questionar em que medida e de que forma a sociedade e o Estado atuam para minimizar os efeitos dessa crise, particularmente os impactos sobre o meio ambiente.

Segundo Marchetto (2009), esse processo de reconhecimento de uma crise ambiental (ou conscientização) inicia-se ao final da década de 1960, quando o intenso desenvolvimento das ciências biológicas e humanas produziu reflexões sobre o possível esgotamento dos bens naturais e das questões morais e éticas relacionadas.

No início da década de 1970, mais precisamente em 1972, ocorreu a Conferência de Estocolmo, que discutiu os rumos do processo de destruição da natureza e introduziu, através de Sachs (2002), o conceito de ecodesenvolvimento, mais tarde traduzido na expressão desenvolvimento sustentável.

Sachs apresentou a necessidade de harmonizar as relações de produção com a preservação do meio ambiente através de um desenvolvimento que atenda as necessidades do presente sem comprometer as possibilidades das gerações futuras. 
A ONU, em 1987, pela Comissão Mundial sobre o Meio Ambiente e Desenvolvimento (ou Comissão Brundtland, como ficou mais conhecida), estabelecida para buscar a compreensão das relações entre o desenvolvimento econômico e a preservação ambiental, lançou o relatório Nosso futuro comum, no qual definiu desenvolvimento sustentável como aquele "capaz de permitir a satisfação das necessidades e a sobrevivência das gerações futuras”.

Em 1994, o inglês John Elkington cunhou o conceito triple bottom line, (em português, tripé da sustentabilidade), no qual propõe que a gestão responsável deve equilibrar valores 1) econômico, 2) ambiental e 3) social. O modelo teórico criado, conhecido também como o modelo dos 3 Ps da Sustentabilidade - people (pessoas), profit (lucro), planet (planeta) - , entende o tripé como constituído de dimensões equânimes e interdependentes.

\section{Reação nacional à crise ambiental}

\section{a) Constituição Federal de 1988}

No Brasil, a consciência ecológica nacional foi coroada com a promulgação da Constituição Federal em 1988, que reservou seu Capítulo VI especificamente ao meio ambiente, fato inédito na história jurídica brasileira. Assim, pela primeira vez em todo o ordenamento jurídico pátrio, o meio ambiente recebeu a atenção do legislador originário, que, no artigo $225^{1}$ da Carta Magna de 1988, impôs não apenas ao poder público, como às pessoas físicas e às

1. "Art. $225 \mathrm{CF}$ - Todos têm direito ao meio ambiente ecologicamente equilibrado, bem de uso comum do povo e essencial à sadia qualidade de vida, impondo-se ao Poder Público e à coletividade o dever de defendê-lo e preservá-lo para as presentes e futuras gerações.

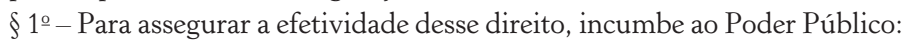

I - preservar e restaurar os processos ecológicos essenciais e prover o manejo ecológico das espécies e ecossistemas;

II - preservar a diversidade e a integridade do patrimônio genético do País e fiscalizar as entidades dedicadas à pesquisa e manipulação de material genético; 
pessoas jurídicas de direito privado, a obrigação de defender e preservar o patrimônio natural de nosso país (Marchetto, 2009).

\section{b) Eco 92 e Rio+20}

A Conferência das Nações Unidas sobre o Meio Ambiente e o Desenvolvimento (Cnumad), também conhecida como Cúpula da Terra ou Eco 92, foi realizada na cidade do Rio de Janeiro, de 3 a 14 de junho de 1992. Ela reuniu 108 chefes de Estado para buscar mecanismos de desenvolvimento sustentável, cujas bases foram

III - definir, em todas as unidades da Federação, espaços territoriais e seus componentes a serem especialmente protegidos, sendo a alteração e a supressão permitidas somente através de lei, vedada qualquer utilização que comprometa a integridade dos atributos que justifiquem sua proteção;

IV - exigir, na forma da lei, para instalação de obra ou atividade potencialmente causadora de significativa degradação do meio ambiente, estudo prévio de impacto ambiental, a que se dará publicidade;

V - controlar a produção, a comercialização e o emprego de técnicas, métodos e substâncias que comportem risco para a vida, a qualidade de vida e o meio ambiente;

VI - promover a educação ambiental em todos os níveis de ensino e a conscientização pública para a preservação do meio ambiente;

VII - proteger a fauna e a flora, vedadas, na forma da lei, as práticas que coloquem em risco sua função ecológica, provoquem a extinção de espécies ou submetam os animais a crueldade.

$\S 2$ - Aquele que explorar recursos minerais fica obrigado a recuperar o meio ambiente degradado, de acordo com solução técnica exigida pelo órgão público competente, na forma da lei.

§ 3 - - As condutas e atividades consideradas lesivas ao meio ambiente sujeitarão os infratores, pessoas físicas ou jurídicas, a sanções penais e administrativas, independentemente da obrigação de reparar os danos causados.

§ 4o - A Floresta Amazônica brasileira, a Mata Atlântica, a Serra do Mar, o Pantanal Mato-Grossense e a Zona Costeira são patrimônio nacional, e sua utilização far-se-á, na forma da lei, dentro de condições que assegurem a preservação do meio ambiente, inclusive quanto ao uso dos recursos naturais.

$\S 5$ o- São indisponíveis as terras devolutas ou arrecadadas pelos Estados, por ações discriminatórias, necessárias à proteção dos ecossistemas naturais.

$\S 6$ - As usinas que operem com reator nuclear deverão ter sua localização definida em lei federal, sem o que não poderão ser instaladas." 
lançadas em 1972, quando a ONU organizou sua primeira conferência ambiental, em Estocolmo, e em 1987, quando o relatório Nosso futuro comum, das Nações Unidas, lançou o conceito de desenvolvimento sustentável.

Durante o período de realização da Eco 92, o então presidente da República, Fernando Collor de Mello, com o apoio do secretário do Meio Ambiente da Presidência da República, José Goldemberg, transferiu provisoriamente a capital federal de Brasília para o Rio de Janeiro, cidade que recebeu reforço de segurança das forças armadas. Também foi criado, em 1992, o Ministério do Meio Ambiente para coordenar a Política Nacional do Meio Ambiente e dos Recursos Hídricos.

A Eco 92 ajudou a popularizar questões ambientais no Brasil e em outros países, conscientizando as nações ricas a ajudar aquelas em desenvolvimento na implantação de uma economia sustentável. Após negociações marcadas por diferenças de opinião entre os chamados primeiro e terceiro mundos, a reunião produziu a Agenda 21, documento com 2.500 recomendações sobre como atingir o desenvolvimento sustentável, incluindo determinações que preveem a ajuda de nações ricas às pobres. A Convenção da Biodiversidade, também produzida durante a reunião, estabeleceu metas para preservação da diversidade biológica e para a exploração sustentável do patrimônio genético, sem prejudicar ou impedir o desenvolvimento de cada país.

A Eco 92 também firmou a Convenção do Clima, que apresentou estratégias de combate ao efeito estufa. Essa convenção deu origem ao Protocolo de Quioto, pelo qual as nações ricas deveriam reduzir suas emissões de gases que causam o aquecimento anormal da Terra. A Declaração de Princípios sobre Florestas, também criada na conferência, garantiu aos Estados o direito soberano de aproveitar suas florestas de modo sustentável, de acordo com as necessidades de desenvolvimento de cada país.

Um dos mais importantes documentos da época da Eco 92 foi a Carta da Terra, que é uma declaração de princípios éticos fundamentais para criação de uma sociedade global justa, sustentável e 
pacífica. O texto incluiu as dificuldades em transitar para maneiras sustentáveis de vida e desenvolvimento humano sustentável.

Dentre os resultados da Cúpula da Terra, a Agenda 21 é considerada como o resultado mais importante. O documento foi assinado por 179 países na ocasião, é um texto-chave com as estratégias que deveriam ter sido adotadas para a sustentabilidade. Já seguida em diversas cidades por todo o mundo, inclusive por meio de parcerias e de intercâmbio de informações, esse compromisso leva em conta, principalmente, as especificidades e as características particulares de cada localidade, de cada cidade, para planejar o que deve ser desenvolvimento sustentável em cada uma.

Após 20 anos da Eco 92, o Brasil sediou a Rio+20, nome dado à Conferência das Nações Unidas sobre Desenvolvimento Sustentável ocorrida na cidade do Rio de Janeiro de 13 a 22 de junho de 2012, que reuniu lideranças e grupos de 193 países-membros da ONU, cujo principal objetivo foi renovar e reafirmar o engajamento dos países em relação ao desenvolvimento sustentável, podendo ser considerado, portanto, uma segunda fase da Cúpula da Terra (Eco 92).

Os principais temas debatidos foram o balanço dos últimos vinte anos em relação ao meio ambiente; a importância e os processos da economia sustentável; ações para garantir o desenvolvimento sustentável do planeta; mecanismos de eliminação da pobreza mundial; e a governança internacional no campo do desenvolvimento sustentável.

\section{c) Política Nacional de Resíduos Sólidos}

Após mais de vinte anos de discussão no Congresso, a Lei n.12.305, de 2 de agosto de 2010, instituiu a Política Nacional de Resíduos Sólidos (PNRS) no país, que foi regulamentada pelo Decreto n.7.404, de 23 de dezembro de 2010.

A lei apresenta diversos pontos importantes para a gestão e o gerenciamento de resíduos sólidos dentro do país, respeitando-se, prioritariamente, a seguinte ordem: não geração, redução, reutili- 
zação, reciclagem, tratamento dos resíduos sólidos e, por fim, a disposição final ambientalmente adequada (em aterros, por exemplo).

Dentre as principais exigências previstas, destacou-se a extinção dos "lixões" no Brasil até agosto de 2014, a disposição final ambientalmente adequada dos rejeitos (resíduos que não podem ser reutilizados nem reciclados) em aterros; a proibição da catação e da criação de animais, bem como a instalação de moradias, nos aterros.

Além disso, a lei também previu a expansão da coleta seletiva de materiais recicláveis, com a inserção prioritária das cooperativas ou associações de catadores, determinando que as prefeituras realizassem a compostagem dos resíduos orgânicos.

A PNRS também visa à responsabilidade compartilhada pelo ciclo de vida do produto entre fabricantes, importadores, distribuidores e comerciantes, consumidores e titulares dos serviços públicos de limpeza urbana e de manejo dos resíduos sólidos, cada um com sua parcela de participação no processo, desde a obtenção da matéria-prima até seu correto descarte, inserindo a logística reversa como "instrumento de desenvolvimento econômico e social que visa à coleta e à restituição dos resíduos sólidos ao setor empresarial para que esses possam ser reaproveitados de diversas maneiras ou retornem ao ciclo produtivo" (São Paulo, 2013, p.11).

Segundo a Secretaria do Meio Ambiente do Governo do Estado de São Paulo (2013), destacam-se como princípios da PNRS:

- a prevenção e a precaução;

- o princípio do poluidor-pagador e do protetor-recebedor;

- o desenvolvimento sustentável;

- a ecoeficência;

- a responsabilidade compartilhada do ciclo de vida dos produtos;

- o reconhecimento de que o resíduo sólido reutilizável e reciclável é um bem econômico e de valor social, gerador de trabalho e renda, e promotor de cidadania e respeito às diversidades locais e regionais. 
No caso dos resíduos sólidos urbanos, aqueles provenientes de residências, estabelecimentos comerciais e prestadores de serviços, o gerenciamento deve ser feito de modo integrado e envolve diferentes órgãos da administração pública e da sociedade civil.

A Prefeitura é a principal responsável pelo gerenciamento de resíduos sólidos do município, e é dela a incumbência de organizar o sistema de limpeza urbana e o manejo desses resíduos, definindo de que forma o gerenciamento vai funcionar por meio do Plano de Gestão Integrada de Resíduos Sólidos, considerando as atividades de coleta domiciliar (regular e seletiva), transbordo, transporte, triagem para fins de reutilização ou reciclagem, tratamento, disposição final, varrição, capina e poda de árvores em vários logradouros públicos, e outros eventuais serviços.

Os impactos socioambientais decorrentes da disposição inadequada dos resíduos sólidos urbanos são: a degradação do solo, o comprometimento dos corpos d'água e mananciais, a contribuição para a poluição do ar e proliferação de vetores de importância sanitária nos centros urbanos, a catação de lixo em condições insalubres nos logradouros públicos e nas áreas de disposição final.

\section{d) Coleta seletiva solidária}

A coleta seletiva solidária é uma estratégia que busca a construção de uma cultura institucional para um novo modelo de gestão dos resíduos, que reconhece os catadores como um dos elementos centrais de um programa de gestão compartilhada de resíduos sólidos.

No âmbito nacional, o Decreto Federal n.5.940/06 instituiu a separação dos resíduos recicláveis descartados pelos órgãos e entidades da administração pública federal direta e indireta determinando que a sua destinação seja para as associações e cooperativas de catadores de materiais recicláveis.

Segundo a Unicef, em 2000, estimava-se que, no Brasil, mais de 40 mil pessoas viviam diretamente da catação em lixões e mais de 30 mil nas ruas, constituindo-se em sua única opção de renda. 
Atualmente, algumas estimativas apontam para mais de 200 mil pessoas envolvidas na atividade de catação e a retirada de catadores dos lixões ${ }^{2}$ e sua inserção em programas de coleta seletiva de lixo possibilitam a melhoria de qualidade de vida, com impactos positivos na saúde dessa população, mostrando-se fundamentais no sentido de resgatar a cidadania e a autoestima dessas pessoas.

A organização dos catadores em associações e cooperativas de trabalho segue os preceitos da economia solidária. Singer (2002) evidencia a importância do significado social do caso dos catadores e das iniciativas de cooperação entre catadores. $\mathrm{O}$ autor afirma que "a cooperativa possibilita compras em comum a preços menores e vendas em comum a preços maiores [...] é uma oportunidade de resgate da dignidade humana [...] e de desenvolvimento" (Singer, 2002, p.89).

O conceito de autogestão é o cerne da economia solidária, que Singer (2002) resume como "ninguém manda em ninguém", ou "todos mandam igual", e que significa, em última instância, que o gerenciamento da cooperativa tem de ser obrigatoriamente feito a partir do sistema "um homem - um voto".

No entanto, a prática da autogestão exige esforços adicionais porque, além das tarefas rotineiras, existe a preocupação com problemas gerais da empresa, o envolvimento em conflitos interpessoais e a participação em reuniões (Singer, 2002, p.19).

Mesmo no contexto de autogestão, a participação do setor público é fundamental para garantir o funcionamento desses grupos, ainda que a coleta seletiva seja realizada oficialmente.

Alguns fatores interdependentes certamente pesam mesmo quando a coleta seletiva é realizada pelas cooperativas de catadores: a) ela exige informação e educação das pessoas para que possam separar o material reciclável e conservá-lo em um estado tal que possa ser reinserido na cadeia produtiva, reduzindo, assim, o porcentual

2. Valores apontados no Relatório final dos programas municipais de coleta seletiva de lixo como fator de sustentabilidade dos sistemas públicos de saneamento ambiental na Região Metropolitana de São Paulo. 
de rejeito; b) quanto menor a fração não reaproveitável, maior a sustentabilidade de um projeto de coleta seletiva, seja do ponto de vista ambiental, seja do ponto de vista socioeconômico; c) para que a coleta seletiva se viabilize, é preciso haver demanda do setor produtivo para os produtos recicláveis.

Apesar desses desafios, a coleta seletiva solidária passou a fazer parte do gerenciamento integrado de resíduos sólidos urbanos e os catadores organizados passaram a desenvolver a gestão compartilhada destes.

\section{e) Gestão de resíduos sólidos em Araraquara-SP}

Araraquara está localizada no centro-leste do estado de São Paulo. Pertencente à Região Administrativa Central, Araraquara possui uma área municipal de $1.002 \mathrm{~km}^{2}$, e sua população, juntamente com o distrito de Bueno de Andrada, é de 208.662 habitantes (IBGE, Censo 2010).

O município faz fronteira com São Carlos, Ibaté, Matão, Gavião Peixoto, Américo Brasiliense, Motuca, Santa Lúcia, Boa Esperança do Sul e Rincão, é banhado pelos rios Anhumas, Chibarro, Cabaceiras, Araraquara, Ribeirão das Cruzes e Córrego do Ouro, pertencentes às bacias hidrográficas dos rios Moji-Guaçu e Jacaré-Guaçu, e conta com grandes áreas verdes para visitação pública.

Até 1976, os resíduos sólidos domiciliares de Araraquara eram recolhidos às fazendas, que detinham o direito sobre esse material através de licitação pública. Os resíduos, basicamente compostos por material orgânico, eram destinados à alimentação de animais, mais tarde comercializados na cidade, prática que colocava em risco a saúde pública, além de acarretar a poluição ambiental, já que os resíduos entravam em decomposição sem qualquer forma de tratamento.

O fim do contrato de licitação do poder municipal com as fazendas, associada com a proibição da Vigilância Sanitária em fazer a "engorda" de aves e suínos com o material descartado, fez que 
a Prefeitura procurasse uma alternativa para a destinação final do lixo produzido na cidade.

A solução veio de um projeto elaborado pela Vigilância Sanitária municipal, à época subordinada à Secretaria de Estado da Saúde, e a escolha da área deu-se em virtude da existência de uma "cratera" no local formada pela retirada sistemática de solo. É importante ressaltar que não existiam exigências ambientais para vazadouros de lixo naquela época em nenhuma esfera administrativa. Entretanto, o solo argiloso do local evitou impactos ambientais consideráveis.

Depois de onze anos, em 1987, o município implantou uma usina de triagem e compostagem de resíduos com o objetivo de transformar o material orgânico que chegava ao vazadouro em composto a ser aplicado na agricultura. Apesar do fracasso da experiência devido à falta capacitação técnica dos responsáveis pelo empreendimento, a usina de compostagem foi desativada apenas em 2003.

Durante um período, a esteira continuou em funcionamento para atender a Cooperativa Acácia, que trabalha no local na separação e na comercialização de materiais recicláveis, dentro de uma estratégia governamental de coleta seletiva solidária.

Posteriormente, a usina foi recuperada. Apesar das condições precárias, o aterro funcionava em área licenciada pela Cetesb. A licença de instalação foi obtida em 18 de agosto de 1988, e a licença de funcionamento em 2 de fevereiro de 1998. A partir do ano de 2014, a Cetesb enquadrou a área como aterro controlado, mediante os índices classificatórios aferidos para a composição do Inventário Estadual dos Resíduos Sólidos Domiciliares, publicação anual da Secretaria de Estado do Meio Ambiente de São Paulo, cuja primeira edição foi lançada em 1998 (São Paulo, 1998).

\section{A Cooperativa Acácia}

De 1991 a 2001, no município de Araraquara, cerca de quarenta pessoas trabalhavam no aterro com a catação de materiais 
recicláveis em meio ao lixo doméstico, o que configurava uma situação de exclusão social, caracterizada por riscos de acidentes e danos à saúde inerentes à atividade, além do estigma social de serem associados ao lixo com o qual conviviam.

A partir de outubro de 2001, a Secretaria Municipal de Desenvolvimento Econômico e da Secretaria Municipal de Desenvolvimento Urbano, através da Coordenadoria de Meio Ambiente, interveio no local, organizando um grupo com 35 catadores independentes que ali sobreviviam.

O grupo foi estimulado e orientado pelo poder público municipal a criar a Associação Acácia dos Trabalhadores de Materiais Reaproveitáveis de Araraquara, juridicamente constituída no ano de 2002, a partir da qual passaram a construir condições dignas para trabalhar na separação dos materiais recicláveis, fundamentada nos princípios da economia solidária e em estatuto próprio.

No final de 2005, a associação passou por um processo de transformação que a transformou na Cooperativa Acácia de Catadores, Coleta, Triagem e Beneficiamento de Materiais Recicláveis de Araraquara, constituída juridicamente em fevereiro de 2006, ano em que foi lançado o projeto de Coleta Seletiva Solidária de Araraquara, em uma parceria entre a Prefeitura Municipal de Araraquara, o Daae - responsável pela política de resíduos sólidos do município - e a Cooperativa Acácia, após aprovação da Lei Municipal n.6496/2006, que autorizou o município a celebrar convênio com a Acácia, objetivando o desenvolvimento de projetos e ações relacionados à coleta, à triagem e ao beneficiamento dos materiais recicláveis.

A partir do convênio, foi assinado o Contrato Administrativo n.1.643 em 21 de agosto de 2008, cujas partes eram, de um lado, o Daae e, de outro, a Cooperativa Acácia de Catadores, Coleta, Triagem e Beneficiamento de Materiais Recicláveis, que pressupôs

dispensa de licitação n.005/2008 do Contratante, requisito n.1186 de 20/8/2008, visando a contratação da Cooperativa para a execução de coleta de materiais recicláveis porta a porta em toda 
a área urbana do município de Araraquara e execução de triagem do material coletado e sua preparação para comercialização...

Isso instituiu que a Cooperativa seria a prestadora dos serviços de coleta seletiva e receberia um pagamento por esses serviços, possibilitando inúmeras melhorias nas condições de trabalho e de recursos financeiros aos cooperados.

Atualmente, a Cooperativa Acácia conta com 180 cooperados e é responsável pela coleta seletiva de toda a cidade, além de desenvolver projetos de educação ambiental em parceria com centros de formação, escolas e universidades.

Desde 2008, as quantidades de materiais recicláveis recolhidos começaram a ser planilhadas e analisadas constantemente, através da construção de gráficos e planos de ação e, em um período de sete anos, pode-se observar um aumento de cerca de 300\% na quantidade de material recolhido, em que a Cooperativa salta da coleta de 150 toneladas por mês no ano de 2008 para um pouco mais de 600 toneladas por mês em 2014, sendo mais de 450 toneladas que deixaram de ir para os aterros e foram devolvidas para a cadeia produtiva.

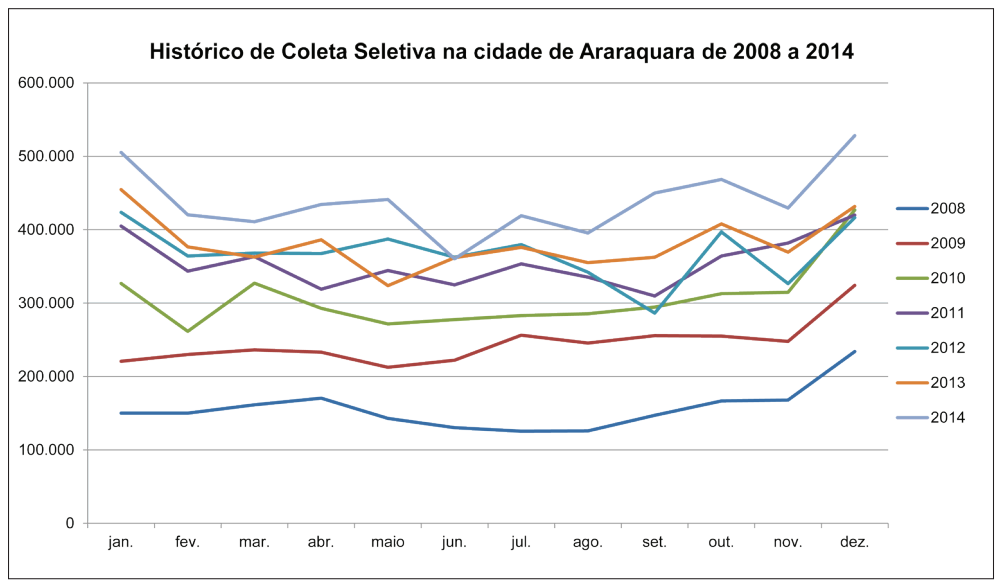

Fonte e elaboração: Cooperativa Acácia. 
Esse resultado deve-se ao desempenho dos cooperados, que, a cada mês, avançam na gestão e gerenciamento desse tipo de resíduo, e de toda a população de Araraquara, cada vez mais consciente do seu papel na busca de uma cidade mais sustentável.

\section{O projeto e os heróis para um futuro sustentável}

Com o objetivo de aproximar os estudantes da Unesp da comunidade araraquarense, apoiar e fortalecer o trabalho da Cooperativa, colaborando na ampliação das atividades de educação ambiental, no processo de inserção social e econômica dos catadores, e na redução dos impactos ambientais, o Projeto AdministrAÇÕES adotou a metodologia apresentada por John Elkington, cuja proposta para o desenvolvimento sustentável é equilibrar 1) valor ambiental, 2) valor social e 3) valor econômico, orientados pelos conceitos de sustentabilidade e triple bottom line ou tripé da sustentabilidade. $\mathrm{O}$ modelo é conhecido também como os 3 Ps da Sustentabilidade planet (planeta), people (pessoas) e profit (lucro), onde o tripé se constitui por dimensões equânimes e organicamente interdependentes. Os eixos de atuação do projeto são classificados como: a) educação ambiental, b) valorização do catador e c) otimização do processo produtivo.

O projeto divide-se, ainda, em duas fases: a) "Fase de Desenvolvimento", que envolve, além dos voluntários e bolsistas, os ingressantes do curso de Administração Pública da Unesp de Araraquara; e b) "Fase de Multiplicação", quando os voluntários e bolsistas oferecerão treinamento aos catadores, a fim de que os mesmos se apropriem do projeto, sua metodologia e atividades, e garantam sua continuidade ao longo do tempo, revelando a sustentabilidade das propostas.

Cada um dos eixos apresentados possui, no mínimo, duas atividades planejadas anualmente. Neste capítulo serão relatadas, de forma sucinta, as atividades desenvolvidas e os resultados alcan- 
çados no eixo educação ambiental - Heróis para um futuro sustentável, nos quatro anos do projeto.

As atividades têm início, a cada ano, com uma visita técnica à Cooperativa Acácia. Com essa visita inaugural, os alunos podem conhecer mais de perto o trabalho realizado pelos catadores que executam a coleta seletiva no município de Araraquara, além de interagir com o ambiente visitado, auxiliando os catadores na separação do material. O objetivo da visita consiste em aproximar os universitários das causas que motivam a Cooperativa Acácia: preservação do meio ambiente, inclusão social e geração de renda através da coleta seletiva solidária, além de sensibilizá-los a respeito das condições do planeta. Após a visita, têm início as atividades em cada eixo.

Especificamente, no eixo educação ambiental, no período de 2011 a 2014, o projeto já atendeu mais de oitocentas crianças, divididas em quatro escolas de ensino fundamental, em Araraquara, além dos professores e funcionários. A fase de intervenção e aplicação do projeto nas escolas é precedida de um semestre com reuniões de planejamento, quando a coordenação e os membros do projeto, principalmente os graduandos ingressantes no curso de Administração Pública, participam das reuniões semanais de ATP na escola e, paralelamente, realizam encontros de estudos dirigidos que buscam introduzi-los na problematização sobre o descarte dos resíduos sólidos, dos impactos ambientais e sociais inerentes, e do papel dos gestores públicos e das organizações privadas e do terceiro setor rumo à busca de soluções sustentáveis, bem como da importância social do processo da coleta seletiva solidária de materiais recicláveis, capacitando-os, portanto, para a fase seguinte. Além disso, são desenvolvidos materiais didáticos, adequados à faixa etária dos alunos atendidos, bem como confeccionados folders e cartilhas, vídeos e atividades avaliativas.

No segundo semestre do ano, a equipe do projeto inicia a segunda fase de desenvolvimento, com a atuação direta na escola participante, executando as atividades planejadas, com o objetivo de conscientizar os alunos a respeito da importância da prática de 
ações sustentáveis para a proteção do meio ambiente. São realizadas palestras interativas, explicando o que é coleta seletiva, sua importância e como realizá-la; oficinas com a confecção de brinquedos e objetos de decoração feitos a partir de material reciclado; gincanas, jogos e brincadeiras voltadas para a educação ambiental; apresentação de vídeos a respeito do tema; rodas de leitura; além de atividades aplicadas em sala de aula com a temática e questionários avaliativos. O projeto termina com a elaboração, pelos alunos, de uma carta com propostas de práticas responsáveis, encaminhada aos responsáveis pela escola e divulgada a toda a comunidade escolar, pais e familiares. A partir desse momento, os alunos se tornam "Heróis para um futuro sustentável". Todos os anos, o Projeto AdministrAÇÕES recebe avaliação positiva da direção e dos professores, e integra o projeto político pedagógico das escolas participantes.

\section{Conclusões}

O Projeto AdministrAÇÕES alcançou seus propósitos de demonstrar o valor da sustentabilidade como principal característica e, em razão da metodologia assumida, promoveu a integração dos graduandos com os cooperados; ofereceu àqueles a oportunidade de conhecerem a estrutura, as características, a identidade e o funcionamento da organização trabalhada, além de difundir a semente da sustentabilidade em todas as suas atividades, sobretudo por envolver reflexões e ações sobre a necessidade da promoção de políticas públicas que minimizem os efeitos ambientais e sociais causados pelo descarte incorreto de resíduos sólidos. Por outro lado, por compreender ações de educação, valorização profissional dos catadores e preservação do meio ambiente, apresentou dados de efetiva contribuição à população envolvida e máximo engajamento de alunos de vários cursos de graduação, demonstrando assim sua relevância na formação universitária e no trabalho colaborativo e interdisciplinar proposto. 
A importância da aproximação entre a Universidade, a escola e a sociedade, propiciada pelas atividades desenvolvidas elevou o status do projeto, que deixou de ser apenas uma atividade de extensão e, atualmente, é reconhecido como mais uma estratégia no mecanismo de afirmação da identidade da Cooperativa Acácia, junto à sociedade araraquarense, na promoção da consciência sustentável. As crianças que participaram do projeto assumem o papel de multiplicadores, os verdadeiros "Heróis para um futuro sustentável."

$\mathrm{Na}$ atual era da informação globalizada e compartilhada em tempo real, ações como essas, que inserem o universitário em problemas reais, aproximando-o da comunidade local, espaço social onde as políticas públicas efetivamente se realizam, e ainda promovem a interação entre a Universidade e a sociedade, não podem representar um paliativo. Ao contrário, quando associadas a temáticas como a sustentabilidade e a educação ambiental, podem ter direcionamento para o caminho da atuação ética, coerente, responsável e justa que, por si, potencialize relacionamentos, gere percepção e, principalmente, ganhos para o meio ambiente.

\section{Referências bibliográficas}

BRASIL. Fundação Nacional de Saúde (Funasa). Programas municipais de coleta seletiva de lixo como fator de sustentabilidade dos sistemas públicos de saneamento ambiental na Região Metropolitana de São Paulo. Brasília: Fundação Nacional de Saúde, 2010.

CAPRA, F. O ponto de mutação. 35.ed. São Paulo: Cultrix, 1995.

CONSELHO EMPRESARIAL BRASILEIRO PARA O DESENVOLVIMENTO SUSTENTÁVEL (CEBDS). Guia de comunicação e sustentabilidade. 2008.

COOPERATIVA ACÁCIA. Disponível em: <http://www.acacia coleta.com>. Acesso em: 24 out. 2013.

ELKINGTON, J. Towards the Sustainable Corporation: Win-Win-Win Business Strategies, for Sustainable Development. California Management Review, v.36, n.2, p.90-100, 1994. 
ELLUL, J. A técnica e o desafio do século. Rio de Janeiro: Paz e Terra, 1968.

INSTITUTO BRASILEIRO DE GEOGRAFIA E ESTATÍSTICA (IBGE). Censo 2010. Disponível em: http://cidades.ibge.gov.br/ painel/painel.php?codmun=350320. Acesso em: 2 jun. 2013.

LIMA, T. A. A questão dos resíduos sólidos domiciliares no município de Araraquara/SP. Araraquara, 2010.

MARCHETTO, P. B. A importância da bioética e do biodireito na sociedade atual. Âmbito Jurídico, n.69, 2009. Disponível em: <http://hdl.handle.net/11449/124592>.

MORIN, E. O futuro caminha para o passado. Tempo, Rio de Janeiro, v.1, p.15-20, 1996.

SACHS, I. Caminhos para o desenvolvimento sustentável. Rio de Janeiro: Garamond, 2002.

SÃO PAULO (Estado). Secretaria do Meio Ambiente. Resíduos sólidos. 2.ed. Cadernos de Educação Ambiental, 6. São Paulo: SMA, 2013.

Secretaria do Meio Ambiente. A cidade e o lixo. São Paulo: SMA, Cetesb, 1998.

SINGER, P. Introdução à economia solidária. São Paulo: Fundação Perseu Abramo, 2002.

SOBRAL, H. R. O meio ambiente e a cidade de São Paulo. São Paulo: Makron Books, 1996. 


\title{
8 \\ AÇÕES E REFLEXÕES SOBRE Português COMO LÍNgua Estrangeira (PLE) NA FACULDADE DE CIÊNCIAS E Letras de Araraquara
}

\author{
Nildicéia Aparecida Rocha \\ Maria Cristina Reckziegel Guedes Evangelista \\ Rosangela Sanches da Silveira Gileno
}

\section{Introdução: as primeiras ações... algumas reflexões}

A área de Português como Língua Estrangeira (PLE) no Brasil tem crescido nos últimos vinte anos, considerando, por um lado, a emergência do Mercosul e, por outro, certa estabilidade político-econômica brasileira e as políticas linguísticas de divulgação e fomento da língua portuguesa falada no Brasil (Zoppi-Fontana, 2009). Nesse contexto brasileiro, as universidades, como formadoras de profissionais e, especificamente, de professores de língua portuguesa, promovem cursos para a formação de professores na área, entre os quais se encontram, por exemplo, o curso de formação de professores de português para falantes de outras línguas, da Universidade de Brasília (UnB), e o curso de Letras em português como língua estrangeira da Universidade Federal da Bahia (UFBA), e o atual curso de professores em português como se- 
gunda língua e língua estrangeira (L2/LE), iniciado no ano de 2015 pela Unicamp.

Focalizando a Universidade Estadual Paulista "Júlio de Mesquita Filho" (Unesp), verifica-se que as três faculdades com curso de Letras (câmpus de Assis, câmpus de São José do Rio Preto e câmpus de Araraquara) recebem um número cada vez maior de estrangeiros nos cursos de graduação e pós-graduação, na condição de intercambistas. Diante desse contexto, cresce a demanda pelo oferecimento de cursos de português como língua estrangeira. Por outro lado, existe a necessidade de formar professores para atuar nessa área emergente. Nesse sentido, as três unidades com cursos de Letras oferecem oficinas e cursos de PLE para estrangeiros, por meio de bolsistas e/ou voluntários para tal fim, sob a supervisão de docentes com experiência no ensino-aprendizagem de língua estrangeira e com formação e atuação nos cursos de Letras da Unesp.

O Projeto de Extensão Ensino de Português Língua Estrangeira (PLE) para Estrangeiros nasceu de uma necessidade específica: atender um número cada vez maior de estudantes intercambistas estrangeiros não falantes do português ou luso-falantes de outros países, que começaram a vir para o câmpus de Araraquara da Unesp a partir de 2010. ${ }^{1}$ Tais estudantes precisavam e precisam até hoje adquirir competência linguístico-discursiva e comunicativa na língua portuguesa para acompanhar as aulas em que estavam e estão matriculados e para a comunicação na vida diária. O número de intercambistas aumentou e o projeto foi aprovado em 2012 como projeto de extensão pela Pró-Reitoria de Extensão Universitária (Proex).

A primeira demanda mais concreta para a inserção do português como língua estrangeira na Faculdade de Ciências e Letras (FCLAr), câmpus Araraquara da Unesp, resultou da chegada de

1. É importante esclarecer que, atualmente, o público-alvo do referido projeto de extensão é composto não apenas por intercambistas estrangeiros não falantes do português ou luso-falantes de outros países, que estão temporariamente estudando ou realizando pesquisa na Unesp de Araraquara, mas também por estrangeiros não falantes do português que pertencem à comunidade araraquarense e da região. 
um grupo de estudantes africanos nessa instituição em 2010, no contexto do programa PEC-G (Programa de Estudantes - Convênio de Graduação). E, para atender esses alunos, foi elaborado o primeiro projeto voltado ao PLE na FCLAr, intitulado Português para Estrangeiros, coordenado pela prof ${ }^{\mathrm{a}} \mathrm{dr} \mathrm{r}^{\mathrm{a}}$ Cássia Regina C. Sossolote, do Departamento de Didática desta faculdade. Um projeto voltado para a elaboração de materiais didáticos e para o oferecimento de cursos a falantes de outros idiomas que estão cursando Letras em virtude de acordos de cooperação de natureza internacional.

No final do mesmo ano, após observar o número crescente de estudantes e professores de outras nacionalidades nas quatro unidades da Unesp de Araraquara, confirmou-se a necessidade de criar outros projetos que pudessem atender as demandas provenientes desse público. Aproveitamos a realização do I Encontro de Licenciaturas em Letras (Elil), em novembro, para convidar os professores doutores José Carlos Paes de Almeida Filho (UnB) e Nelson Viana (UFSCar), com larga experiência nessa área, para discutir o tema em palestras e reuniões com docentes e estudantes da FCLAr. Essa iniciativa teve largo apoio das organizadoras do encontro, as professoras doutoras Maria Celeste Consolin Dezotti e Edvanda Bonavina da Rosa, assim como da pós-graduação em Linguística da FCLAr, na pessoa de sua coordenadora, prof ${ }^{\mathrm{a}} \mathrm{dr}$ ํㅡㄹ Rosane de Andrade Berlinck.

A partir do diálogo com esses professores e docentes da FCLAr, decidiu-se organizar um curso de extensão que pudesse, ao mesmo tempo, motivar os docentes a refletir sobre o PLE a partir das áreas de ensino e pesquisa específicas de cada um, assim como formar estudantes, futuros profissionais da área de Letras, para atuar nesse âmbito como professores.

O curso de extensão, denominado Tópicos de Ensino e Aprendizagem de PLE teve como coordenadoras as professoras doutoras Marina C. Mendonça, Nildicéia A. Rocha e Maria Cristina R. Guedes Evangelista, em uma ação conjunta dos Departamentos de Letras Modernas e Linguística. Como colaboradores de outra insti- 
tuição, participaram o prof. dr. Nelson Viana (Departamento de Letras, UFSCar) e o mestrando Julio Orlando Gallardo (Programa de Pós-Graduação em Linguística da UFSCar). Foram abertas inicialmente trinta vagas, imediatamente preenchidas e ampliadas para cinquenta, sendo que $86 \%$ dos inscritos concluíram o curso.

Os principais objetivos desse curso de extensão foram:

1. Propiciar o (re)conhecimento do ensino e da aprendizagem de PLE, passando por variadas perspectivas teórico-analíticas e históricas.

2. Estimular uma visão crítico-reflexiva sobre o ensino e a aprendizagem de PLE por meio de análise de bibliografia específica e de material didático impresso e virtual e contato com professores e pesquisadores atuantes na área.

Os tópicos abordados em cada aula e os docentes responsáveis são apresentados no quadro que segue:

\begin{tabular}{|c|c|c|}
\hline 1 & Prof. Dr. Nelson Viana & $\begin{array}{l}\text { Contextualização e historicização do } \\
\text { ensino e da aprendizagem de PLE }\end{array}$ \\
\hline 2 & Prof. Dr. Arnaldo Cortina & $\begin{array}{l}\text { PLE na FCL. Importância e necessidades } \\
\text { para sua implantação. Considerações sobre } \\
\text { livros didáticos }\end{array}$ \\
\hline 3 & $\begin{array}{l}\text { Prof }{ }^{a} \text { Dr }{ }^{\mathrm{a}} \text { Nildicéia Aparecida } \\
\text { Rocha }\end{array}$ & PLE no Mercosul \\
\hline 4 & Prof - Dra ${ }^{a}$ Alessandra Del Ré & $\begin{array}{l}\text { Aquisição e aprendizagem de língua } \\
\text { estrangeira e bilinguismo }\end{array}$ \\
\hline 5 & Prof ${ }^{a}$ Dr ${ }^{a}$ Silvia Beatriz Adoue & $\begin{array}{l}\text { PLE para participantes de movimentos } \\
\text { sociais latino-americanos }\end{array}$ \\
\hline 6 & Prof. Julio Orlando Gallardo & $\begin{array}{l}\text { Um panorama sobre a formação do } \\
\text { professor de português no contexto de } \\
\text { educação superior na Universidad } \\
\text { Nacional de Entre Rios, Argentina }\end{array}$ \\
\hline 7 & $\begin{array}{l}\text { Prof }{ }^{-} \text {Dra Marina Célia } \\
\text { Mendonça } \\
\text { Profa Dra Renata M. F. C. } \\
\text { Marchezan }\end{array}$ & $\begin{array}{l}\text { O acordo ortográfico da língua portuguesa } \\
\text { e a promoção linguística em tempos de } \\
\text { globalização - relação entre linguagem e } \\
\text { política }\end{array}$ \\
\hline
\end{tabular}


(continuação)

\begin{tabular}{|c|c|c|}
\hline 8 & $\begin{array}{l}\text { Prof }{ }^{\underline{a}} \text { Dr }^{\mathrm{a}} \text { Cristina Martins } \\
\text { Fargetti }\end{array}$ & $\begin{array}{l}\text { Política linguística no Brasil (envolvendo } \\
\text { comunidades indígenas e discutindo o } \\
\text { Inventário Nacional da Diversidade } \\
\text { Linguística - INDL) }\end{array}$ \\
\hline 9 & $\begin{array}{l}\text { Prof }{ }^{a} \text { Dra Rosane de Andrade } \\
\text { Berlinck }\end{array}$ & $\begin{array}{l}\text { Norma e variação: que português ensinar } \\
\text { como PLE? }\end{array}$ \\
\hline 10 & Prof. Dr. Luiz Carlos Cagliari & Fonética e ensino de línguas estrangeiras \\
\hline 11 & $\begin{array}{l}\text { Prof }{ }^{a} \text { Dr }^{\mathrm{a}} \text { Gladis Massini } \\
\text { Cagliari }\end{array}$ & A Fonologia no ensino de PLE \\
\hline 12 & $\begin{array}{l}\text { Prof. Dr. Odair Luiz Nadin } \\
\text { da Silva }\end{array}$ & Ensino de vocabulário e uso de dicionário \\
\hline 13 & $\begin{array}{l}\text { Prof }{ }^{a} r^{\underline{a}} \text { Silvana Vieira } \\
\text { Amorim }\end{array}$ & $\begin{array}{l}\text { Civilização brasileira para estrangeiros de } \\
\text { língua francesa }\end{array}$ \\
\hline 14 & $\begin{array}{l}\text { Prof }{ }^{a} r^{a} \text { Maria Cristina } \\
\text { R. G. Evangelista } \\
\text { Prof }{ }^{a} \text { Dra Maria Glória } \\
\text { C. Mazzi }\end{array}$ & $\begin{array}{l}\text { Apresentação e análise de material } \\
\text { didático (impresso e virtual) no } \\
\text { ensino de PLE }\end{array}$ \\
\hline 15 & Prof ${ }^{a}$ Dre ${ }^{\underline{a}}$ Paula Tavares Pinto & $\begin{array}{l}\text { Contribuições da Linguística Aplicada } \\
\text { para o ensino de PLE: introdução a } \\
\text { aspectos linguístico-culturais com o } \\
\text { auxílio da tecnologia }\end{array}$ \\
\hline
\end{tabular}

Como resultado das primeiras reflexões realizadas nesse curso, somadas à demanda existente, fomos motivados a oferecer aulas de PLE para os estudantes estrangeiros, obtendo, para tanto, o engajamento de catorze estudantes matriculados no curso de extensão. Foram, assim, criadas as Oficinas de PLE, cadastradas na Proex como um Projeto de Evento Acadêmico e oferecidas durante dois meses, em encontros semanais, para as quais se inscreveram 25 alunos estrangeiros.

Os objetivos dessas oficinas foram:

1. Promover o primeiro contato de alunos do curso de Letras com as áreas de ensino e aprendizagem de PLE, levando-os a estudar questões teóricas relacionadas à prática em sala de aula, a analisar e escolher material didático e a utilizar os conceitos estudados e os materiais escolhidos com alunos estrangeiros. 
2. Desenvolver a competência dos estrangeiros na língua portuguesa.

Os estudantes envolvidos nas oficinas participaram de reuniões periódicas para discutir questões teórico-metodológicas com a prof ${ }^{a}$ Nildicéia A. Rocha, que os orientou e compartilhou com o grupo sua experiência anterior na formação de professores de PLE. Durantes dois meses, esses estudantes ensinaram PLE a alunos falantes de diferentes línguas maternas, como espanhol (da América do Sul e da Espanha), inglês, alemão, chinês, tcheco e francês.

As primeiras ações relativas ao PLE desenvolvidas na FCLAr atingiram diferentes esferas. Nas aulas presenciais dialogadas do curso de extensão, buscou-se delinear um panorama dessa área no Brasil e no exterior, pois esse curso representou para muitos dos docentes e discentes participantes um primeiro momento de reflexão e de estudo sobre questões referentes ao ensino e à aprendizagem de PLE. Além do contato com questões teóricas, eles tiveram a oportunidade de conhecer e avaliar livros didáticos, de informar-se sobre exames de proficiência para estrangeiros e sobre instituições que promovem o ensino de PLE, entre outros temas.

Para os docentes, o curso representou, além disso, uma oportunidade de considerar pontos de intersecção entre sua área de atuação e o ensino e a pesquisa no âmbito do PLE e de compartilhar essas reflexões com colegas e alunos.

Aos futuros profissionais, cerca de cinquenta estudantes de Letras, os temas tratados apresentaram também novas perspectivas de trabalho. Os estudantes que ministraram as oficinas de PLE sob orientação de docentes do Departamento de Letras Modernas da FCLAr puderam unir teoria à prática, observando, entre outras questões, como se manifestam os diferentes estilos de aprendizagem dos estrangeiros e a influência da língua materna na aprendizagem.

Acima de tudo, as primeiras ações desenvolvidas na FCL abriram caminho para novos cursos de extensão, projetos de pesquisa na graduação e na pós-graduação, como veremos a seguir. 


\section{O Projeto Ensino de Português como Língua Estrangeira (PLE) para estrangeiros: ensino, pesquisa e extensão}

Tendo em vista a crescente demanda pelo ensino e aprendizagem de PLE na Faculdade de Ciências e Letras, câmpus Araraquara, o referido projeto de extensão nasceu com o objetivo de promover duas ações fundamentais para a implantação dessa área. Por um lado, oferecer oficinas de PLE a estrangeiros falantes de outras línguas e a luso-falantes de outros países, e, por outro, criar espaços para as áreas de ensino e pesquisa sobre PLE durante a formação acadêmica de alunos da graduação e da pós-graduação do curso de Letras da FCLAr.

Inicialmente, para atender à primeira meta, as oficinas foram ministradas por licenciandos do curso de Letras da FCLAr, sob a coordenação, orientação e supervisão da prof ${ }^{\mathrm{a}}$ dra Nildicéia A. Rocha, propiciando o desenvolvimento da competência comunicativo-discursiva e o contato com aspectos culturais e interculturais aos estrangeiros estudantes nas unidades da Unesp de Araraquara, a saber: Faculdade de Ciências e Letras, Faculdade de Farmácia, Faculdade de Odontologia e Instituto de Química, além de estrangeiros moradores em Araraquara e região. A posteriori, alunos da pós-graduação (mestrandos e doutorandos) passaram a colaborar nessas oficinas, assim como a prof ${ }^{\underline{a}} \mathrm{dr}^{\mathrm{a}}$ Rosângela S. S. Gileno, que passou a ser docente colaboradora do projeto a partir de 2013.

Hoje, o Projeto de Extensão Ensino de Português como Língua Estrangeira (PLE) para Estrangeiros da FCLAr propõe um programa de atividades sociais e linguísticas dentro e fora da sala de aula que possam integrar o aluno estrangeiro no contexto social da Unesp, da cidade e da região e, ao mesmo tempo, garantir-lhe oportunidades de desenvolver habilidades linguístico-discursivas, pragmáticas e interculturais. Nesse sentido, nosso objetivo mais amplo é criar espaços e momentos de convivência e aprendizagem em que o aluno estrangeiro possa adquirir competência no uso do PLE na universidade e fora dela. Nosso contexto específico con- 
tinua a abranger as quatro unidades da Unesp de Araraquara e nosso público-alvo são os alunos intercambistas dos cursos de graduação e dos programas de pós-graduação dessas unidades, assim como estrangeiros da comunidade externa. Na FCLAr, os participantes do projeto de extensão correspondem a:

1. Bolsistas e voluntários (alunos da graduação e de pós-graduação em Letras): cabe-lhes ministrar aulas de PLE para os estrangeiros e elaborar, com o coordenador e o colaborador, relatórios parcial (final do primeiro semestre) e final (final do segundo semestre). Todo o grupo, especialmente os bolsistas e voluntários, dedica-se ao planejamento e execução das atividades sociais e linguísticas fora da sala de aula como encontros, eventos, visitas, palestras.

2. Docente coordenadora e docente colaboradora: com funções de coordenar e auxiliar, respectivamente, nas tarefas de acompanhar o processo de ensino de PLE durante o desenvolvimento do projeto, realizado pelos bolsistas e voluntários, orientando-os e supervisionando seu percurso docente; realizar reuniões semanais com os bolsistas e voluntários; promover debates on-line na plataforma Moodle entre estrangeiros e bolsistas/voluntários, bem como entre coordenador, colaborador e bolsistas/voluntários; participar do processo de avaliação contínua e pontual.

Metodologicamente, o projeto desenvolve as seguintes atividades:

1. Diagnóstico: entrevista inicial com os estrangeiros para saber expectativas, necessidades, interesses e conhecimento sobre a língua portuguesa e cultura brasileira e prova escrita para avaliar habilidades de compreensão e produção discursivo-comunicativas em nível básico (A1 e A2), intermediário básico (B1 e B2) e intermediário avançado (C1), equivalentes ao exame Celpe-Bras e ao Quadro Europeu 
Comum de Referência (QECR) para a Língua Portuguesa como Língua Estrangeira (PLE).

2. Formação de turmas de acordo com o conhecimento de língua portuguesa e língua de origem, seguindo os níveis de proficiência orientados pelo QECR.

3. Seleção dos bolsistas, após publicação de edital de inscrição, por meio de uma aula didática de PLE, entrevista e análise de currículo.

4. Preparação dos bolsistas, com reuniões periódicas e indicação de leitura de textos teóricos e metodológicos sobre ensino de línguas estrangeiras, especialmente de PLE.

5. Elaboração de plano de curso de PLE para estrangeiros de acordo com as indicações observadas no item Diagnóstico de cada turma formada.

6. Oficinas de PLE oferecidas semestralmente.

7. Planejamento e realização de atividades sociais e culturais (confraternização no Centro Cultural Professores Heleieth e Waldemar Saffioti na Chácara Sapucaia da Unesp, festas do Rotary, palestras, visitas a museus, eventos culturais no Sesc, congressos, festas típicas da cidade, exposições etc.).

8. Reuniões semanais entre coordenadora, colaboradora, bolsistas e voluntários para discutir textos lidos previamente e aulas passadas e futuras, organizar a participação do grupo em eventos ou mesmo organizar eventos, entre outros temas.

Em relação à área de ensino e aprendizagem de PLE para o futuro professor, licenciando do curso de Letras e participante do projeto, a mais significativa contribuição refere-se às leituras teóricas e metodológicas e às discussões que realizamos nas reuniões semanais, nas quais refletimos sobre ser docente de língua estrangeira considerando ser a língua portuguesa nossa língua materna, sobre os procedimentos didáticos realizados em sala de aula, sobre os livros didáticos disponíveis no mercado brasileiro e internacional e a elaboração de material didático de PLE, sobre as aulas ministradas e as dúvidas dos bolsistas e voluntários, entre outros aspectos 
que surgem no desenvolvimento do projeto, dentro de uma abordagem crítico-reflexiva para o ensino de línguas.

Desse modo, busca-se mobilizar conhecimentos teóricos e reflexões sobre a prática, em uma inter-relação indissociável, realizando leituras de texto na área de Linguística Aplicada ao ensino de língua estrangeira, especificamente ao ensino de PLE, como os textos de Almeida Filho e Lombello (1989), Almeida Filho (1992, 1997), Viana (2007, 2014), Zoppi-Fontana (2009), entre outros, assim como textos sobre metodologia de ensino de línguas estrangeiras, como Richards e Rodgers (1986), Pérez (2009), Leffa (1988); de políticas linguísticas, como Oliveira (2007); sobre livros didáticos, como Paiva (2009), entre outros.

Sobre as oficinas de PLE, estas têm como objetivo específico o desenvolvimento da competência discursivo-comunicativa dos alunos estrangeiros intercambistas, e, para esse público-alvo, as metas são: desenvolver habilidades linguístico-comunicativas e culturais em PLE; desenvolver habilidades de compreensão e produção discursivo-comunicativas em níveis básico, intermediário e avançado; trabalhar as estruturas linguístico-discursivas de uso e funcionamento de PLE; mostrar a diversidade histórico-cultural do mundo lusófono por meio da expressão de vários gêneros discursivos, dentre eles a música brasileira representativa de cada região do Brasil; desenvolver a produção de textos escritos e orais em língua portuguesa falada no Brasil, especificamente textos de nível acadêmico quando necessários; desenvolver uma atitude de reflexão e autonomia diante da diversidade intercultural que se poderá observar em cada grupo de alunos, na relação da língua estrangeira com a língua portuguesa falada no Brasil.

O plano de curso das oficinas de PLE é estruturado contemplando as necessidades e os interesses de cada grupo, com o seguinte conteúdo programático mínimo:

1. Noções gramático-textuais: pronúncia dos sons da língua portuguesa do Brasil, assim como da região Sudeste, São Paulo, Araraquara; formas e valores de artigos, substantivos, 
adjetivos, pronomes pessoais, demonstrativos, numerais, advérbios, conjugação verbal regular e formas irregulares do indicativo, subjuntivo, imperativo, gerúndio, particípio e infinitivo; introdução das formas de mecanismo de coesão e coerência descritiva, narrativa e argumentativa etc.

2. Práticas linguístico-discursivas: expressão e compreensão de marcas de pessoa, espaço e tempo; expressões de gostos e opiniões; formas ligadas à cortesia; produção oral e escrita de textos; aquisição de vocabulário etc.

3. Noções histórico-regionais: foco nas cinco regiões do Brasil por meio de expressões musicais que representam a história e a cultura de cada região; audição e compreensão de músicas de cada região brasileira; apresentação de expressões idiomáticas etc.

4. Aspectos culturais e interculturais que representam o Brasil, tanto internamente como nos países estrangeiros.

Portanto, o projeto tem como objetivo propiciar aos estrangeiros ferramentas linguístico-discursivas e culturais, por meio de aulas de PLE e atividades culturais, promovendo maior inserção nas atividades acadêmicas dentro e fora do câmpus, possibilitando efetiva participação dos estrangeiros comunicativamente, tanto nas aulas da graduação como da pós-graduação e com os docentes e funcionários da Unesp de modo geral. O projeto justifica-se também por sua abrangência externa e internacional, dando mais visibilidade e representatividade às ações da Unesp referentes ao ensino de PLE no Brasil.

De fato, o projeto tem ampliado suas ações, com a demanda de cursos para outros públicos. Nesse sentido, convém salientar que a FCLAr recebe estudantes chineses para o curso de Letras. Para atendê-los, a professora coordenadora e a professora colaboradora do projeto organizam, com bolsistas e voluntários, aulas de PLE em encontros de vinte horas semanais. Para os falantes de mandarim, organizam-se aulas específicas sobre o exame Celpe-Bras, 
utilizando as instruções disponíveis no site do Inep. ${ }^{2}$ Essas aulas funcionam como preparatório para a realização do exame.

Nesse projeto de extensão, não apenas o público-alvo aumentou. Há a participação crescente de um número significativo de bolsistas e voluntários. ${ }^{3} \mathrm{O}$ grupo é composto basicamente por alunos da graduação em Letras, mas também por professores do curso de Letras já formados, vinculados à FCLAr como reingressantes, assim como alunos do mestrado e do doutorado que participam do projeto com o objetivo de adquirir conhecimentos teóricos e experienciar atividades de ensino na área de PLE, na condição de voluntários.

O grupo de graduandos que participa do projeto é renovado parcialmente a cada ano (em geral, os alunos saem do projeto somente depois de formados em Letras). Além de participar das oficinas e das reuniões por um período consideravelmente longo, esses graduandos se desenvolvem na área de PLE depois de formados ou decidem por aperfeiçoar seus estudos nessa área, por meio da realização de mestrado e doutorado, fator que muito justifica a continuidade do projeto.

A seguir, são apresentados os resultados promovidos até o presente momento com o desenvolvimento deste projeto de extensão.

\section{Os resultados promovidos pelo projeto}

Os resultados esperados traçados no projeto dizem respeito à formação discursivo-comunicativa dos estrangeiros intercambistas da Unesp de modo que os mesmos, ao final de sua temporada na universidade, desenvolvam competência comunicativa intercultural, que significa muito mais que ser comunicativamente competente na língua-alvo. De fato, significa integrar língua e cultura, de

2. Disponível em: <http://portal.inep.gov.br/celpebras>. Acesso em: 15 mar. 2014.

3. Atualmente são sete alunos da graduação e cinco da pós-graduação atuando no projeto como bolsistas ou voluntários. 
modo que o aluno estrangeiro adquira, além de habilidades linguísticas que possibilitem sua comunicação com a cultura-alvo ou com diferentes culturas, a capacidade de relacionar sua cultura nacional com esta(s) outra(s) cultura(s). No que diz respeito especificamente à língua-alvo, como já foi relacionado nos objetivos do projeto, espera-se que o aluno estrangeiro desenvolva habilidades de compreensão e produção discursivo-comunicativas em nível básico e intermediário; reconheça as estruturas linguístico-discursivas de uso e funcionamento do Português como Língua Estrangeira (PLE); reconheça a diversidade histórico-cultural do mundo lusófono; produza textos escritos e orais em língua portuguesa falada no Brasil, especificamente textos de nível acadêmico quando necessários; desenvolva atitude de reflexão e autonomia diante da diversidade intercultural.

Para os alunos do curso de Letras, o projeto, por meio das oficinas e reuniões teórico-práticas semanais com o grupo, proporciona oportunidades de estudo, pesquisa e experiência pedagógica de ensino de PLE durante sua formação inicial. Convém esclarecer que, na atual grade do curso da FCLAr, não há formação específica na área de PLE. Desse modo, o projeto é um espaço rico para que alunos da graduação em Letras possam ter acesso à leitura e às pesquisas nessa área ainda relativamente nova no Brasil e que muito precisa ser trabalhada devido ao crescente processo de internacionalização do país e das universidades.

Para o Programa de Pós-Graduação da FCLAr, a inserção de PLE na formação inicial dos alunos do curso de Letras desperta o interesse dos mesmos para aprofundarem seus estudos sobre PLE, desenvolvendo projetos de mestrado e doutorado nas áreas de: Ensino e Aprendizagem de Línguas, Sociolinguística, Análise do Discurso, Linguística Aplicada. Convém mencionar que, na pós-graduação, foi oferecida no segundo semestre de 2014 a disciplina intitulada "Tópicos de ensino e aprendizagem de Português Língua Estrangeira (PLE)", para mestrandos e doutorandos do Programa de Pós-Graduação em Língua Portuguesa e Linguística da FCLAr, sendo a responsável pela disciplina a prof ${ }^{\underline{a}}$ dra ${ }^{\underline{a}}$ Nildicéia Aparecida 
Rocha, contando com a colaboração dos professores Nelson Viana (UFSCar), Rosângela Sanches Silveira Gileno (FCLAr/Unesp) e Cássia Sossolote (FCLAr/Unesp).

Relacionando ensino e pesquisa, temos como resultado do projeto a participação ativa do grupo de PLE em eventos e congressos da área, como a organização do Simpósio O Vocabulário como Objeto de Ensino e Aprendizagem em Espanhol como Língua Estrangeira (ELE) e em Português como Língua Estrangeira (PLE) no I Congresso Internacional Estudos do Léxico e suas Interfaces (Cineli), o qual se realizou na FCLAr/Unesp, de 7 a 9 de maio de 2014; a apresentação do grupo no II Simpósio Internacional Celpe-Bras (Sincelpe)nos dias 25 e 26 de setembro de 2014 na Universidade Estadual de Campinas com a comunicação "Ensino de português para chineses: repensando os preparatórios para o exame Celpe-Bras"; no II Colóquio Ação e Reflexão em Português para Estrangeiros (Carpe) - UFSCar - 12 e 13 de dezembro de 2014, com a comunicação "Reflexões sobre experiências didáticas na sala de aula de PLE para aprendizes chineses" e a apresentação do pôster Ensino de Português como Língua Estrangeira (PLE) para estrangeiros na I Mostra dos Trabalhos de Extensão do Câmpus de Araraquara - Unesp, realizado no dia 12 de dezembro no Instituto de Química, entre outras.

No que diz respeito aos resultados esperados que se referem à universidade e à comunidade externa, podemos dizer que, para a universidade, o projeto Ensino de Português como Língua Estrangeira (PLE) para estrangeiros, cujo foco é a inserção comunicativa dos estrangeiros no convívio acadêmico, significa também uma fonte de divulgação da língua e cultura brasileira para todos os países de origem dos intercambistas. Uma vez que os estrangeiros tornam-se capazes de se comunicar com mais fluidez, desenvoltura e adequação linguístico-pragmática discursiva e cultural, o impacto externo é visível, tendo em vista a maior inserção desses alunos na comunidade tanto dentro como fora da universidade e principalmente ao voltar para suas universidades estrangeiras de origem. 
Desse modo, a FCLAr, sediando projetos dessa natureza, torna-se polo de divulgação nacional e internacional da língua e cultura brasileira, ampliando relações internacionais. Como prova disso, tivemos alguns resultados de amplo conhecimento como:

1. O aumento significativo do número de convênios entre a FCL com outras instituições internacionais.

2. O aumento também no número de estrangeiros recebidos pela instituição, totalizando aproximadamente sessenta estrangeiros durante o semestre de 2014, advindos de diversos países e com variadas línguas maternas como espanhol (em suas diversas variantes latinas), inglês, francês, finlandês, coreano, mandarim, alemão, urdu, desde o nível elementar (A1) ao nível avançado (C1).

Para a comunidade acadêmica e citadina de Araraquara há maior inserção do estrangeiro em sua estadia na FCL, na cidade e no país. Assim, podemos observar que o projeto desenvolve aspectos culturais e interculturais para a inserção do estrangeiro em nosso meio acadêmico e citadino, regional e brasileiro. Como prova disto, temos que os intercambistas estrangeiros, ao longo do projeto, participam de várias atividades sociais, culturais e científicas (festas do Rotary, palestras, visitas a museu, eventos culturais no Sesc, congressos, festas típicas da cidade, exposições etc.). Um dos eventos culturais de que participam é organizado semestralmente pelo grupo, o Encontro Intercultural Brasil-Mundo na Chácara Sapucaia, entre estrangeiros, bolsistas, voluntários e convidados, como modo de socialização inter/multicultural. Cabe ainda esclarecer que foi iniciado um grupo, denominado Clube da Conversa - PLE, com o intuito de desenvolver a troca de experiências e apoio para as possíveis dificuldades linguísticas e/ou culturais que os estrangeiros possam encontrar, além de proporcionar a aprendizagem da língua, umas vez que as conversas são feitas em língua portuguesa. 
Além desses resultados, outros foram obtidos pelo trabalho e dedicação dos estrangeiros:

- Aprovação de quatro alunos dentre sete que prestaram o exame de proficiência Celpe-Bras no ano de 2014.

- Proposta de trabalho de intérprete (mandarim/português) a uma aluna chinesa, participante do projeto, por uma emissora de televisão durante a Copa do Mundo em 2014; e aprovação de um aluno do projeto no processo seletivo de voluntários para o mesmo evento.

\section{Desafios e dificuldades encontrados}

Desde as primeiras ações no processo de implantação da área de PLE na FCLAr, encontraram-se vários desafios. Primeiramente, a falta de um estudo detalhado sobre as necessidades específicas dos estrangeiros vindos para cada unidade da Unesp de Araraquara, para sua devida inserção tanto no âmbito acadêmico como citadino e regional. Ademais, a área de PLE na FCLAr, para atender o projeto de extensão, encontra dificuldades de vários aspectos, como a falta de materiais específicos nessa área, livros didáticos, livros sobre metodologia de ensino de PLE etc.; falta de apoio financeiro para a participação em eventos na área, entre outras. Convém esclarecer que, mesmo com o apoio da Pró-Reitoria de Extensão em aprovar este projeto, o desenvolvimento acontece a passos lentos e muitas vezes com recursos próprios.

\section{Considerações finais}

Foi apresentado o percurso traçado até o momento na área de Português Língua Estrangeira na FCLAr que, certamente, não difere muito dos caminhos percorridos pelos colegas das outras universidades. Nessa instituição, partiu-se de um curso de extensão 
para estudantes de graduação cujo conteúdo programático precisa ser retomado e ampliado em novas disciplinas e cursos. Com a aprovação como projeto de extensão, tem sido possível atender a demanda relativa aos estrangeiros que atuam na Unesp e na cidade de Araraquara. Como consequência no âmbito acadêmico, observa-se um crescente interesse por parte dos licenciandos em atividades de pesquisa e ensino nesta área de formação do futuro professor do curso de Letras.

Por ter iniciado esse trabalho mais recentemente, pôde-se contar com experiências e publicações anteriores. Observou-se, no entanto, que algumas das dificuldades enfrentadas continuam a fazer parte da realidade em outras instituições que nos antecederam, mostrando que ainda precisa ser consolidado um espaço para o PLE nas universidades brasileiras, que poderá ser ocupado em conjunto pelos departamentos responsáveis pelos cursos de Letras.

As primeiras ações desenvolvidas na FCLAr abriram caminho para novos cursos de extensão, projetos de pesquisa na graduação e na pós-graduação. No entanto, essa instituição necessita de docentes e pesquisadores que tenham o PLE como área de especialização e que possam formar professores competentes para atender o número crescente de estrangeiros no Brasil e contribuir para a cooperação entre a Unesp e as universidades estrangeiras. Para tanto, é preciso reconhecer o PLE como uma área de atuação em si mesma, para que deixe de ser uma atividade a que docentes e discentes se dedicam paralelamente a suas áreas de atuação propriamente ditas.

\section{Referências bibliográficas}

ALMEIDA FILHO, J. C. P.; LOMBELLO, L. C. (Orgs.). Parâmetros atuais para o ensino de português língua estrangeira. Campinas: Pontes, 1997.

. Identidade e caminhos no ensino de português para estrangeiros. Campinas: Pontes, 1992. 
ALMEIDA FILHO, J. C. P.; LOMBELlO, L. C. (Orgs.). O ensino de português para estrangeiros: pressupostos para o planejamento de cursos e elaboração de materiais. Campinas: Pontes, 1989.

LEFFA, V. J. Metodologia do ensino de línguas. In: BOHN, H. I.; VANDRESEN, P. Tópicos em Linguística Aplicada: o ensino de línguas estrangeiras. Florianópolis: Ed. da UFSC, 1988. p.211-36.

OLIVEIRA, G. M. A "virada político-linguística” e relevância social da Linguística e dos linguistas. In: CORREA, D. A. (Org.). A relevância social da Linguística: linguagem, teoria e ensino. São Paulo: Parábola Editorial, 2007. p.79-93.

PAIVA, V. L. M. de O. História do material didático de língua inglesa no Brasil. In: DIAS, R.; CRISTÓVÃO, V. L. L. (Orgs.). O livro didático de línguas estrangeiras: múltiplas perspectivas. Campinas: Mercado de Letras, 2009. p.17-56.

PÉREZ, A. S. La enseñanza de idiomas en los últimos cién años: métodos y enfoques. Madri: S.G.E.L, 2009.

RICHARDS, J. C.; RODGERS, T. S. Approaches and Methods in Language Teaching. Cambridge: Cambridge University Press, 1986.

VIANA, N. Pesquisa-ação e ensino/aprendizagem de língua estrangeira: do percurso metodológico às implicações educacionais e sócio-políticas. In: ALVAREZ, M. L. O.; SILVA, K. A. da (Orgs.). Linguística Aplicada - múltiplos olhares. Campinas: Pontes, 2007. p.233-52.

Compreendendo o Exame Celpe-Bras. In: MULIK, K. B.; RETORTA, M. S. (Orgs.). Avaliação no ensino-aprendizagem de línguas estrangeiras: diálogos, pesquisas e reflexões. v.1. Campinas: Pontes, 2014. p.263-70.

ZOPPI-FONTANA, M. O português do Brasil como língua transnacional. Campinas: RG, 2009. 


\section{9 \\ Cine Campus: \\ HISTÓRIA, MEMÓRIA E AÇÃO}

Fabiane Renata Borsato

[...] siempre hubo dos clases de cinefilia. Una acrítica, acumulativa, monumental, esencialmente conservadora $y$ en última instancia represiva y hasta snob. La otra está relacionada con el descubrimiento de que el cine puede ser una alternativa contra la falsedad de la sociedad. Pero eso depende del cine que se elija, del cine que se busque, de la libertad y de la lucidez con que se lo integre con pasiones que deben necesariamente exceder la obsesión de verlo todo.

(Quintín, 2005, p.15)

A relação da Faculdade de Ciências e Letras com o cinema é extensa. Basta recordar o papel fundamental da Sessão Zoom e sua importância para a universidade e a sociedade araraquarense nas quatro últimas décadas do século XX, com as relevantes exibições de filmes de qualidade, por preços populares, nos cines Veneza e Capri.

A Sessão Zoom criou uma forte tradição de projetos na área cinematográfica na universidade que teve continuidade na figura do Cine Campus. Um projeto de extensão geralmente é fruto do ensino e da pesquisa do coordenador. Entretanto, no caso do Projeto de Extensão Universitária Cine Campus, sua concepção tem 
outra motivação, fortemente ligada à afeição de seus criadores e realizadores pela arte cinematográfica.

No ano de 2001, nasce o Cine Campus com papel semelhante ao da Sessão Zoom, ou seja, o de exibir cinema de qualidade. Coordenado por alunos dos cursos de Ciências Sociais e Letras, o Cine Campus atuou até 2009 na realização de curadoria e exibição fílmica no câmpus de Araraquara. O êxito do projeto promoveu, em 2009, a sua institucionalização. Suas ações extensionistas eram voltadas para a comunidade interna, sendo elas a exibição semanal de filmes e o apoio a disciplinas, cursos e eventos que fizessem uso do cinema para discussão dos conteúdos programáticos. Essas atividades são mantidas até os dias atuais.

O Projeto Cine Campus atendia a espectadores basicamente formados por alunos dos cursos de Humanidades e seu primeiro desafio era estender suas ações para a comunidade externa, sendo notável, embora bastante germinal, a intenção de formação fílmica do público.

Em 2009, o projeto contava com a coordenação de professores do Departamento de Letras Modernas e com a colaboração de alunos do Curso de Letras da Faculdade de Ciências e Letras de Araraquara. Embora os integrantes do projeto tivessem formação na área de Letras, nenhum deles desenvolvia pesquisa sobre cinema, sendo, portanto, a afeição pela sétima arte o principal motivo de manutenção do Cine Campus.

De 2012 até os dias atuais, é possível dizer que o projeto promoveu movimento contrário. A atual coordenadora orientou e orienta pesquisas de mestrado e iniciação científica na área de literatura e cinema, participou como colaboradora de uma disciplina da pós-graduação intitulada Poéticas da Modernidade: Teatro, Cinema e Literatura e iniciou projeto de pesquisa sobre a metalinguagem na literatura e no cinema. Sendo assim, é possível afirmar que um projeto de extensão tem potencial para gerar transformações curriculares, projetos de pesquisa e novos processos de ensino-aprendizagem. 


\section{Cine Campus}

O Cine Campus é um projeto de extensão universitária da Unesp que promove ações internas e externas à Faculdade de Ciências e Letras, dentre elas a exibição periódica de filmes de qualidade artística no câmpus, abertas à comunidade interna e externa, às terças e quintas-feiras, período vespertino e/ou noturno, com entrada gratuita; a formação fílmica dos participantes por meio de cursos, debates, grupos de estudos e desenvolvimento de pesquisa; a inserção do cinema e de suas relações intertextuais como área de conhecimento importante na escola pública de ensino; o oferecimento de cursos de extensão, palestras e eventos sobre cinema, com especialistas; o estabelecimento de parcerias com departamentos, centros acadêmicos e seções da faculdade para realização de atividades culturais conjuntas; a criação de espaços de pesquisa sobre cinema, providos de livros e DVDs que facilitem o acesso à arte do cinema ao grande público; a divulgação da programação fílmica em meios digitais e impressos; participação de seus integrantes em eventos sobre cinema; orientação de projetos de iniciação científica e de mestrado na área de cinema; organização do arquivo Cine Campus para preservação da memória do projeto.

\section{O trabalho em grupo: método e ação}

O Projeto Cine Campus depende da participação efetiva de todos os seus integrantes. Devido ao número de atividades desenvolvidas, todos os integrantes têm responsabilidades e funções a cumprir. As atividades são distribuídas em reunião, sendo que o integrante escolhe a função que deseja realizar de acordo com suas afinidades. A presença em todas as sessões do Cine Campus é obrigatória a todos os integrantes devido à preocupação da coordenadora com a formação fílmica dos alunos. A participação em outras atividades é feita de modo democrático para que haja maior envolvimento dos alunos a partir de suas próprias escolhas. 
A curadoria fílmica é realizada por integrante(s) mais experiente(s) ou com referencial fílmico de qualidade, previamente informado à coordenadora. Uma vez concluída a curadoria, a coordenação toma ciência e às vezes sugere substituição ou acréscimo de filmes. Depois disso, cabe a todos os integrantes a divulgação de informações novas, propostas de trabalho e eventos, para que tudo seja decidido democraticamente, em reuniões com a coordenação.

\section{As contribuições}

As atividades culturais extracurriculares contribuem para o estabelecimento de novas práticas de ensino e desenvolvimento de linhas de pesquisa. O Projeto Cine Campus, comprometido com a comunidade acadêmica interna e com a sociedade, procura criar mecanismos de formação na área da arte cinematográfica.

O projeto complementa a formação do aluno diretamente envolvido com as atividades de gestão, pesquisa e ensino, ligadas à utilização pedagógica do cinema. $\mathrm{O}$ grupo discente, integrante do projeto, frequenta cursos de extensão; desenvolve pesquisas para a curadoria dos filmes da programação; planos de aula para participação no Projeto Cinema e Literatura na Escola; consciência da prática docente, pois, após as aulas ministradas, há reuniões para discussão dos aspectos positivos e negativos das estratégias pedagógicas e metodológicas empregadas. Além disso, os integrantes do projeto lidam com novas mídias para manutenção de blog, redes sociais e confecção de cartazes de divulgação das atividades. Ainda é possível afirmar que o projeto contribui com o conhecimento sobre relações interpessoais, adquiridos nos momentos das parcerias e da reflexão sobre as dificuldades encontradas durante as ações e possíveis soluções para os problemas enfrentados.

Quanto ao público beneficiado pelos eventos e sessões fílmicas, o Projeto Cine Campus propicia um referencial sólido sobre a arte cinematográfica, construído sessão a sessão, em debates e palestras com especialistas. Incentiva o desenvolvimento de projetos 
de iniciação científica; favorece o contato e diálogo do aluno do ensino fundamental e médio com a instituição de ensino superior, ao promover atividades educativas na escola pública de ensino; impulsiona a formação cinematográfica do público participante por meio do conhecimento de filmes pouco divulgados e da exposição de conteúdos sobre a história do cinema e de suas principais estéticas e gêneros.

\section{Um pouco da história do Cine Campus e de suas dificuldades}

Em 2009, o Projeto Cine Campus institucionaliza-se é avaliado pela Proex com pontuação mediana, 31 pontos. Recebe para desenvolvimento de suas atividades uma bolsa de 800 reais. Para um projeto iniciante, é possível afirmar que já contava com boa aceitação tanto do público quanto da instituição.

Em 2010, um dos coordenadores do projeto passa a ocupar função docente em outra universidade e a atual coordenadora recebe duplo convite. $\mathrm{O}$ primeiro propõe participação no evento Ciclo de Cinema Kim Ki Duk, momento em que realiza o debate de quatro filmes do diretor coreano. O segundo convite foi a coordenação do Projeto Cine Campus.

Era o início de uma nova relação com o cinema e com suas potencialidades artísticas e educacionais. Promover intercâmbio de conhecimento tornou-se meta fundamental do Cine Campus. O evento Ciclo de Filmes Comentados: Ingmar Bergman cumpriu esse papel ao apresentar, no mês de setembro, os filmes $O$ sétimo selo, Fanny E Alexander, A hora do lobo e O silêncio, com palestra do professor João Ribeirete, da Universidade de Lisboa, especialista na obra de Bergman. $\mathrm{O}$ ano de 2010 anunciou importantes perspectivas. 


\section{1: ano de conquistas}

O Projeto Cine Campus, no primeiro semestre de 2011, criou novas e importantes vias de articulação de ensino, pesquisa e extensão. Além da exibição semanal de filmes no anfiteatro B da Faculdade de Ciências e Letras, ação realizada desde a origem do projeto, foi incluído em suas atividades o Projeto Cinema e Literatura na Escola, que, uma vez ao mês, exibiu aos alunos de primeiro ano do ensino médio da Escola Estadual Bento de Abreu (EEBA) de Araraquara um filme baseado em obras literárias ou que dialogasse com a literatura, discutindo a contiguidade entre os dois sistemas semióticos. As exibições fílmicas foram precedidas e sucedidas de debate com a coordenadora do Projeto Cine Campus e com integrantes bolsistas e voluntários. Antes das sessões na EEBA, cada grupo responsável pelo debate e exposição de conteúdos apresentou um plano de aula à coordenadora para verificação da viabilidade e de necessários ajustes. Os encontros mensais foram avaliados positivamente pelos integrantes do Cine Campus, não só pelo interesse demonstrado pelos alunos do ensino médio e pela boa receptividade da direção e da coordenadoria do EEBA, mas também pela possibilidade de desenvolvimento e aprendizado da atividade docente por parte dos integrantes do Projeto Cine Campus.

A atividade cumpriu importante papel social ao oferecer conhecimentos sobre a teoria do texto literário e sobre a linguagem cinematográfica a 38 alunos do ensino médio. Na terceira sessão, alguns alunos já usavam a terminologia própria à linguagem cinematográfica (plano, sequência, montagem) e faziam leituras mais apuradas dos textos literários e fílmicos. A sessão de encerramento do curso ocorreu na Faculdade de Ciências e Letras, sendo que os alunos puderam conhecer a faculdade e vivenciar um pouco de sua rotina. $\mathrm{O}$ objetivo principal para tal deslocamento dos alunos do EEBA foi a interação com a faculdade e a tentativa de despertar o desejo de frequentá-la futuramente.

A presença da equipe Cine Campus na escola pública propiciou não só a comunicação entre Universidade e comunidade 
externa e a alteração da rotina dos alunos e dos conteúdos programáticos, mas o conhecimento, por parte dos integrantes do Cine Campus, do contexto de sala de aula e da realidade do ensino público. Apesar das muitas críticas ao ensino fundamental e médio, a relação estabelecida entre a equipe Cine Campus e a primeira série do ensino médio da Escola Estadual Bento de Abreu foi bastante diversa, baseada no respeito mútuo, na troca de conhecimento e no diálogo. Parece que o cinema e a literatura mediaram essa relação de modo positivo e isso beneficiou a construção de novas percepções, menos cristalizadas, da realidade escolar. Uma integrante do Cine Campus, após o primeiro encontro do Projeto Cinema e Literatura na Escola, decidiu inscrever-se para a prática docente e, após um mês, tornou-se professora eventual na referida escola.

Além dessa atividade de ensino, a equipe Cine Campus discutiu a necessidade de formação dos integrantes na área de cinema. Outra ação definida foi a elaboração de uma série de cursos de extensão que oferecessem formação cinematográfica aos integrantes e demais interessados.

O curso de extensão Roteiro de Cinema: Teoria e Análise ocorreu no primeiro semestre de 2011, com carga horária de trinta horas. Houve a colaboração do assistente de suporte acadêmico IV da Staepe e bacharel em Imagem e Som, Plinio Ricardo Garutti Moreira. O curso foi ministrado pela coordenadora do Projeto Cine Campus e pelo colaborador, sendo oferecido aos integrantes do projeto e pesquisadores da área de cinema.

As parcerias internas em 2011 foram fortemente marcadas pelas necessidades de algumas disciplinas e eventos. O Cine Campus exibiu filmes na Semana do Trabalho, com debate do Grupo de Trabalho e Trabalhadores do Departamento de Ciências Sociais; nos eventos Semana Mandarim e Cinema, Café e Hip Hop e no curso de extensão Construções Discursivas da Grande Cidade - entre Modernidade e Pós-Modernidade: Paradigmas e Tradições Europeias, que contou com a presença de docente da Universidade do Minho convidado pelo Programa de Pós-Graduação em Estudos Literários. 
Além das parcerias, o projeto organizou eventos, tais como Cinema, Café e Debate - Para Sempre Lilya: Jogos de Câmera, Ficção e realidade; Semana Saramago; Semana da Animação, Mostra Kiarostami e A Estética Surrealista cinematográfica: Luís Buñuel na Etapa Mexicana, todos com a presença de debatedores especialistas.

Outra ação importante que teve início em 2011 foi a atualização do acervo de filmes da biblioteca da FCLAr. A verba recebida pelo Cine Campus foi destinada à compra de discos digitais (DVD) e livros sobre cinema. Os integrantes realizaram pesquisa de bibliografia básica sobre cinema para aquisição de livros e filmes da curadoria. Todo o material, após exibição, foi doado ao acervo da biblioteca. Atualmente, a biblioteca da FCLAr apresenta a sala Cine Campus, com importante acervo de filmes e livros sobre história, teoria e crítica do cinema.

O Cine Campus foi convidado a participar da XIV Feira de Profissões da FCLAr, apresentando o projeto de extensão no estande da feira, por meio de banner explicativo dos objetivos do projeto e distribuição de folders ao público visitante. Ainda participou do VIII Congresso de Extensão Universitária da UFSCar, São Carlos, com apresentação de painel de divulgação do projeto e comunicação oral sobre o projeto de iniciação científica na área de Cinema e Literatura de uma integrante bolsista do Cine Campus. A divulgação do Cine Campus também chegou a Águas de Lindoia, com apresentação de comunicação oral sobre o projeto no VI Congresso de Extensão da Unesp.

Quanto à visibilidade e ao reconhecimento do papel social do Cine Campus, em todas as reuniões dos integrantes com a coordenação são discutidas ações para aumento do número de espectadores, uma vez que o público do Cine Campus é diverso em cada época do ano, sendo bastante reduzido no período de avaliações semestrais. Os integrantes do Cine Campus realizaram pesquisa de opinião com alunos do câmpus sobre a aprovação dos horários e dias das sessões de cinema. A pesquisa ocorreu no final do ano de 2010 e apontou a sugestão de exibições noturnas, ação realizada desde 2011. 
Outra proposta dos integrantes do projeto, para conquista da fidelidade do público, foi a emissão de certificados de assistência a filmes. A certificação é emitida a alunos que comprovem um mínimo de $75 \%$ de presença em cada ciclo.

Outro fator relevante que anunciou transformações no quesito pesquisa foi a proposta de dois projetos de iniciação científica na área de cinema, desenvolvidos por um integrante bolsista do Projeto Cine Campus e por um aluno de graduação, ambos sob orientação da coordenadora do Cine Campus, sendo o início de transformações substanciais da pesquisa da coordenação do Cine Campus.

\section{2 e seus percalços}

Como é de praxe, o Projeto Cine Campus, sempre que convidado a atuar em outras instituições, opta por realizar um primeiro contato para verificação da aceitação do projeto, para, em seguida, propor a continuidade. Esse modo de atuação também foi adotado quando, em outubro de 2012, a Fundação "Prof. Dr. Manoel Pedro Pimentel" (Funap), que atua no âmbito da Secretaria da Administração Penitenciária nas áreas de cultura, educação, profissionalização, jurídica, trabalho e geração de renda, solicitou parceria com o Cine Campus para a unidade prisional Centro de Ressocialização Feminino de Araraquara. Foram realizados quatro encontros com as detentas para exibição de filmes, debate e proposta de atividades. O êxito do encontro gerou nos integrantes do Cine Campus e no público beneficiário o desejo de continuidade das ações em 2013, por meio de convênio com a Funap, e ainda a extensão das ações para o presídio masculino. Para tanto, foi feita a visita de conhecimento da penitenciária masculina de Araraquara para apresentação do projeto ao diretor e verificação do local em que seria possível realizar as exibições.

Com periodicidade mensal, o Projeto Cinema: Arte de Formação teria por público-alvo detentos da penitenciária masculina e do Centro de Ressocialização Feminino de Araraquara, cuja finalidade 
seria apresentar sessões coordenadas de filmes e promover o conhecimento dos recursos expressivos e da linguagem cinematográfica, colaborando com a formação cultural e fílmica dos detentos e, consequentemente, com sua ressocialização. As exibições fílmicas seriam sucedidas de debate com a coordenação e bolsistas/voluntários do Projeto Cine Campus da Faculdade de Ciências e Letras da Unesp, câmpus Araraquara. A cada sessão, o público entraria em contato com as particularidades do texto fílmico, tais como roteiro, fotografia, som, imagem, montagem, plano, sequência, cena etc. Os filmes seriam selecionados pelo critério de qualidade estética para desenvolver boa formação fílmica do público participante.

O Projeto Cinema: Arte de Formação foi proposto de forma modular, em seis encontros, concentrados em três meses, para garantia da assistência total de todos os detentos, uma vez que alguns poderiam passar por transferência ou soltura. Esse formato permitiria desenvolver a atividade com duas turmas, uma no primeiro semestre de 2013 e outra no segundo semestre do mesmo ano. $\mathrm{O}$ número de favorecidos seria de aproximadamente cem pessoas na penitenciária masculina e cem pessoas no Centro de Ressocialização Feminina, uma vez que cada turma poderia contar com até cinquenta espectadores. A exibição e o debate dos filmes teriam duração de três horas, sendo estabelecido o período vespertino para desenvolvimento das atividades na penitenciária masculina e noturno no Centro de Ressocialização Feminina.

Os trabalhos na penitenciária masculina e no Centro de Ressocialização Feminino não foram realizados devido a impedimentos burocráticos que não permitiram até o momento firmar convênio entre a Unesp e a Secretaria da Administração Penitenciária, apesar dos muitos contatos entre representantes da Funap, coordenadora do Projeto Cine Campus, seção técnica acadêmica e vice-direção da Faculdade de Ciências e Letras de Araraquara. Este foi um dos problemas enfrentados pelo Cine Campus que deixou de atuar em benefício da sociedade por entraves burocráticos. Duzentos detentos da penitenciária masculina e do Centro de Ressocialização Feminina 
foram impedidos de participar de uma atividade cultural de qualidade, favorecedora de sua reinserção social e o Projeto Cine Campus, à espera do convênio, deixou de atuar em outros projetos externos em 2013.

Apesar disso, nem tudo foi balanço negativo nesse ano. O Cine Campus foi convidado a participar da XIII Semana do Livro e da Biblioteca com exibição e debate do filme nacional Narradores de Javé; foi parceiro do Departamento de Letras Modernas na exposição $\mathrm{O}$ Mundo dos Contos de Fadas, atuando na exibição dos filmes Branca de Neve, A Bela Adormecida, Rapunzel e Os músicos de Bremen, produzidos e emprestados pelo Instituto Goethe em comemoração aos duzentos anos de publicação da coletânea compilada pelos irmãos Grimm. Ainda fez parceria com Seda e Colmeia Cultural para o evento Semana do Audiovisual. Organizou o evento Das Páginas do Romance para as Telas de Cinema: Configurações do Horror Gótico nas Adaptações Cinematográficas, bem como a palestra Violência e Racismo na Era dos Fluxos Globais, com debate sobre o filme Táxi, de Carlos Saura.

Outra ação foi a parceria com professores de Língua e Literatura Francesa do Departamento de Letras Modernas para aquisição de um acervo de filmes franceses para exibição em aulas e consequente conhecimento da cultura e da expressiva produção cinematográfica de língua francesa.

Parceria relevante para o desenvolvimento de ensino e pesquisa ocorreu com o Programa de Pós-Graduação em Estudos Literários da FCLAr, no XII Seminário de Pesquisa do Programa de Pós-Graduação em Estudos Literários: Relações Intersemióticas e I Seminário Internacional de Semiótica da Unesp. Na abertura do evento, houve apresentação do Projeto Cine Campus e menção à sua relevância para os cursos de Humanidades e a seu papel de difusor de filmes raros e artísticos. No referido evento, o Cine Campus ainda promoveu dois minicursos sobre cinema. Foram momentos importantes de intercâmbio discente e docente sobre as relações entre cinema e literatura e debate das pesquisas na área do cinema. 
Variedade é outro objetivo do projeto. A Mostra Música Brasileira selecionou quatro filmes sobre a música brasileira e o gênero samba. A última sessão contou com a participação de um músico da cidade de Araraquara que realizou Cine Debate sobre a trajetória histórica do samba. Ao lado dela, está a Mostra Etnodoc, com participação do Núcleo de Antropologia da Imagem e Performance e exibição de dezesseis curtas contemplados pelo edital Mostra Etnodoc, realizado pelo Ministério da Cultura e pelo Instituto do Patrimônio Histórico e Artístico Nacional (Iphan). O ano foi encerrado com a Mostra Cinema e Gastronomia, com duração de uma semana de exibições de filmes sobre a temática e debates com especialistas.

A sala Cine Campus no interior do novo prédio da biblioteca da FCLAr contou com a doação de 146 filmes em DVD e 12 livros sobre cinema para o acervo da biblioteca. As aquisições de 2012 foram 36 livros sobre cinema e 45 DVDs. Todas as aquisições são doadas à biblioteca e disponibilizadas ao público, para empréstimo.

Se, até 2012, as publicações do Cine Campus estavam voltadas para artigos em jornais locais e digitais, em 2013 é nítido o seu desenvolvimento de pesquisa, com publicação de artigos acadêmicos, resumos, apresentação de trabalhos em eventos nacionais, defesa de dissertação de mestrado, produção decorrente das pesquisas de pós-graduação na área de cinema e literatura orientadas pela coordenadora do Cine Campus.

\section{3: momento de mudanças}

A primeira mudança do projeto deu-se no âmbito de sua imagem. A partir de então, o projeto seria identificado pelo novo logotipo, criado pelo artista visual Thiago Buoro. Os cartazes e as divulgações on-line passaram a receber a imagem do Cine Campus, consolidativa de sua identidade fortemente marcada pela exibição e leitura do texto fílmico: 


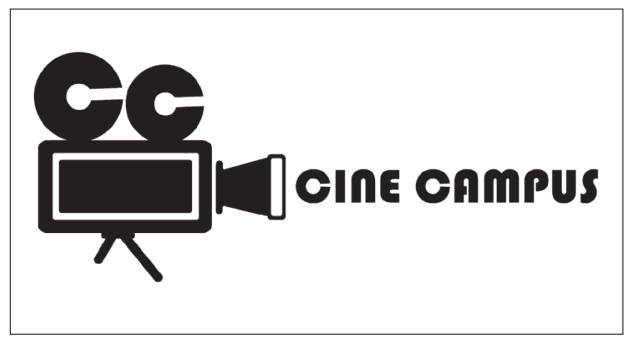

Figura 9.1

A outra mudança ocorreu na forma de seleção dos filmes. Os integrantes do projeto Cine Campus, reunidos, sugeriram a curadoria por ciclos temáticos, históricos, teóricos e críticos, o que representou um avanço no que diz respeito à formação do público, uma vez que os filmes exibidos formaram ciclos coesos e promoveram o conhecimento sólido de estéticas e gêneros cinematográficos diversos, oferecendo ao público autonomia para seleção crítica da produção cinematográfica.

Em 2013, foram exibidos, na faculdade, 58 filmes de qualidade artística. As sessões, seguidas de debates, ganharam maior frequência e tiveram boa aceitação, com depoimentos do público sobre a importância do evento para a compreensão do texto fílmico. Como os meios digitais facilitaram o acesso ao filme, o Cine Campus precisou incentivar o debate como diferencial mobilizador do público.

A parceria externa ocorreu com a Secretaria Municipal de Educação e com o Sesc, ambos de Araraquara. O projeto Cinema, Livros e Bate-Papo levou à biblioteca municipal de Araraquara filmes especialmente selecionados do acervo do Sesc para alunos do ensino fundamental da rede pública. Os educadores avaliaram positivamente a ação tanto pela participação expressiva dos alunos com perguntas e depoimentos sobre sua experiência como espectadores fílmicos, durante o debate, quanto pela qualidade dos filmes.

Outra questão importante é o crescimento do número de discentes com interesse em pesquisa sobre cinema e literatura. Acre- 
ditamos que o Cine Campus contribui significativamente para o desenvolvimento da pesquisa universitária e de novas práticas curriculares, tais como a disciplina Prática como Componente Curricular (PCG) do Departamento de Literatura, que teve por tema, em 2012 e 2013, as relações entre cinema e literatura.

\section{Os integrantes}

O Projeto Cine Campus, desde sua institucionalização, foi avaliado satisfatoriamente, o que lhe concedia bolsas e recursos para desenvolvimento de suas ações. Entretanto, em 2013 e 2014, avaliações insípidas e pareceres equivocados prejudicaram-no substancialmente com a negação de bolsas e verba destinadas pela Proex. $\mathrm{O}$ fato prejudicou várias ações do projeto, tais como a organização da I Semana de Cinema e a atualização do acervo de filmes e livros da biblioteca, ações que dependiam de verba para a realização.

Entretanto, há um aspecto positivo. Os integrantes bolsistas do Cine Campus passaram a atuar como voluntários, mantendo as atividades mínimas em 2013 e planejando novas estratégias em 2014. Uma delas, de fundamental importância, foi deixar de lançar editais para seleção de colaboradores bolsistas ou voluntários e passar a convidar alunos dos primeiros anos, ingressantes, para a participação no projeto. A ação gerou a adesão inicial de cinco novos integrantes que, somados aos três antigos que permaneceram no projeto, compuseram uma equipe com forte atuação cooperativa, visando à manutenção da qualidade do projeto. Trata-se de alunos interessados em cinema e que desenvolveram, em um curto período de tempo, carinho e responsabilidade pelo Cine Campus. O problema da falta de bolsas é que muitos deles são selecionados para outras ações como bolsistas e passam a atuar menos tempo com o Cine Campus, motivo pelo qual a equipe procura estimular novas adesões.

Apesar desse problema, o projeto gerou, em 2013, sob orientação da coordenadora, duas pesquisas de iniciação científica, duas 
dissertações de mestrado, além da formação do Grupo de Estudos da História do Cinema, composto pela coordenadora do Cine Campus e alunos de graduação e pós-graduação com pesquisas na área de cinema e literatura. $\mathrm{O}$ estudo da arte e de seus discursos polissêmicos é essencial para que o indivíduo seja produtor e não reprodutor de linguagens, para que ele possa avaliar de modo crítico e principalmente reflexivo discursos e linguagens diversas.

Atualmente, cada novo candidato a integrante do Cine Campus é convidado para uma reunião de apresentação geral do projeto e para um estágio com os antigos componentes do Cine Campus. Após o cumprimento dessas etapas, a participação do aluno é avaliada, bem como sua permanência ou não.

Tal procedimento tem a intenção de conscientizar o novo integrante de que o aspecto diferencial do Cine Campus é o estudo da linguagem cinematográfica para que o cinema seja tratado como linguagem provida de planos, cenas, sequências, montagem, construção espacial e temporal e outros recursos expressivos. Ao objetivar a formação integral discente, o Cine Campus reforça a importância do cinema para a comunidade interna e externa, como linguagem de muitos códigos que favorece a formação plena do cidadão, por meio do conhecimento de outras culturas e modos de interpretar o mundo. Trata-se, portanto, de um dos poucos projetos de extensão sobre cinema que propõe o estudo dessa arte, motivo por que ele se faz relevante e importante numa Faculdade de Ciências e Letras.

\section{Outros desafios}

A preocupação com a formação do indivíduo na área de cinema e com a importância do cinema para a formação moral, social e intelectual do sujeito, levou a equipe a um projeto ousado e desafiador desenvolvido com crianças de 2 a 6 anos. O projeto Cinema na Infância objetiva despertar o gosto pela arte cinematográfica de qualidade na primeira infância por meio de atividades que tenham como método as técnicas de filmagem e produção do cinema de ani- 
mação. O projeto teve início em abril de 2015, no Centro de Convivência Infantil da Unesp de Araraquara. Cinema na Infância é um projeto com formato modular, desenvolvido com duas turmas, sendo a primeira formada por crianças de 2 a 4 anos e a segunda, com crianças de 4 a 6 anos, atendendo às necessidades do CCI quanto a horários e turmas. O primeiro módulo tratou dos primeiros brinquedos óticos da história do cinema, sendo que alguns deles foram expostos durante o mês de abril para que as crianças se familiarizassem com os objetos.

Outra iniciativa do Projeto de Extensão Universitária Cine Campus relaciona-se à preservação da sua memória. Um relevante material sobre sua história e a da Sessão Zoom, projeto cultural anteriormente mencionado e que precedeu o atual Cine Campus, encontra-se em fase de organização. $\mathrm{O}$ arquivo da memória da Sessão Zoom e do Cine Campus, da década de 1960 até os dias de hoje, está parcialmente digitalizado. Após a organização do material, o mesmo passará pela fase de catalogação, segundo critérios técnicos de identificação, classificação e descrição. Em abril de 2015, parte do arquivo foi exposto ao público, de modo que a história dos cineclubes de Araraquara ficasse conhecida. Após exposição do arquivo, é intenção do Cine Campus disponibilizá-lo à comunidade para consulta e pesquisa, visando à criação de um acervo digital acessível na página da FCL e um arquivo físico preservado pela biblioteca da FCL, devidamente acondicionado, de acordo com orientações de arquivologista e/ou especialista na área.

\section{Considerações finais e provisórias}

O que vai registrado neste artigo é resultado de um projeto em continuidade, portanto, potencialmente apto a gerar novos e relevantes resultados.

Desde 2009, o Cine Campus conseguiu sistematizar o conhecimento adquirido nos últimos anos e estabelecer metas claras para 
uma formação mais sólida de seus integrantes e de seu público na área de cinema.

Atualmente, o projeto deseja manter espaços de exibição e debate de filmes de qualidade artística, promover a compreensão das particularidades da linguagem cinematográfica e dos recursos expressivos empregados nos filmes por meio de eventos e grupos de estudo, estimular o contato e o gosto por filmes de qualidade estética, democratizar a arte e a reflexão sobre ela e, consequentemente, favorecer a formação cultural e artística do público.

Sua relevância no âmbito de uma faculdade contemplada com cursos da área de Humanidades é evidente, uma vez que o cinema é fundamental à formação discente e importante recurso pedagógico. E, como projeto de extensão, o Cine Campus objetiva ações transformadoras da sociedade e de sua adesão a filmes comerciais, feitos para o consumo imediato e acrítico e "eso depende del cine que se elija, del cine que se busque” (Quintín, 2005, p.15).

\section{Referências bibliográficas}

QUINTÍN. Pasiones dudosas. Letras de cine, Barcelona, n.9, 2005. 


\section{SOBRE O ORGANIZADOR}

CLÁUDIO CESAR DE PAIVA - Economista. Doutor em Economia Aplicada pela Universidade Estadual de Campinas - Unicamp (2007). Atualmente é vice-diretor da FCL-Unesp (mandato 2013-2017), professor e pesquisador do Departamento de Economia da Unesp/câmpus Araraquara. Faz parte do Conselho Editorial da Revista de Negócios Internacionais, do Conselho Editorial da Editora Átomo e Alínea de Campinas e do Conselho Editorial da Proex-Unesp. Tem experiência na área de Economia, com ênfase em Economia Regional e Urbana, atuando principalmente nos seguintes temas: desenvolvimento regional, economia brasileira, desenvolvimento econômico, finanças públicas e urbanização brasileira. 


\section{SOBRE OS DEMAIS AUTORES}

ALESSANDRA APARECIDA VIVEIRO - Professora da Faculdade de Educação/Unicamp. Ex-docente da FCLAr/Unesp. Coordenadora do Projeto de Extensão Ciências e Ambiente: Dialogando com a Comunidade Universitária.

ALEXANDRE HARLEI FERRARI - Professor da Educação Básica. Aluno do Programa de Pós-Graduação em Educação Escolar/Unesp. Colaborador em projetos de extensão.

ANA CLAUDIA FERNANDES TERENCE - Docente do Departamento de Administração Pública da FCLAr/Unesp. Colaboradora do Projeto AdministrAÇÕES.

ANDRÉA MIDORI MACHIDA FERRAZ MENDES - Aluna do Curso de Graduação em Letras da FCLAr/Unesp. Bolsista de projetos de extensão.

ARIOVALDO DE OLIVEIRA FILHO -Graduando em Administração Pública pela FCLAr/Unesp. Bolsista do Projeto AdministrAÇÕES.

ARNALDO CORTINA - Professor do Departamento de Linguística, do Programa de Pós Graduação em Linguística e Língua 
Portuguesa e Diretor da Faculdade de Ciências e Letras da Universidade Estadual Paulista "Júlio de Mesquita Filho" - Unesp/ câmpus Araraquara. Coordenador do Grupo de Pesquisa em Semiótica (GPS-Unesp) e membro pesquisador do Grupo Cadernos de Semiótica Aplicada (Grupo CASA).

CARINA TELES DE SOUZA - Aluna do Curso de Graduação em Pedagogia da FCLAr/Unesp. Bolsista de projetos de extensão.

CARLA GANDINI GIANI MARTELLI - Professora do Departamento de Antropologia, Política e Filosofia da Faculdade de Ciências e Letras da Unesp, câmpus Araraquara e do Programa de Pós-Graduação em Ciências Sociais da mesma faculdade.

CÁSSIA REGINA COUTINHO SOSSOLOTE - Professora da Faculdade de Ciências e Letras de Araraquara - Unesp. Vice-Coordenadora do Projeto de Extensão Ler É Viver.

DARBI MASSON SUFICIER - Aluno do Programa de Pós-Graduação em Educação Escolar - Unesp. Licenciado e bacharel em Ciências Sociais pela FCLAr/Unesp.

DAVID TEIXEIRA PINTO - Biólogo. Gestor de Projetos da Cooperativa Acácia de Catadores de Materiais Recicláveis de Araraquara-SP.

DJALMA LAROCCA JUNIOR - Graduando em Administração Pública pela FCLAr/Unesp. Voluntário do Projeto AdministrAÇÕES.

ELTON DE OLIVEIRA BARRETO - Professor da Educação Básica. Aluno do Programa de Pós-Graduação em Educação Escolar/Unesp. Colaborador em projetos de extensão. 
FABIANE RENATA BORSATO - Professora assistente doutora do Departamento de Literatura e docente do Programa de Pós-Graduação em Estudos Literários da Unesp/câmpus Araraquara, nas disciplinas da área de Teoria da Literatura. Membro do grupo CASA da Unesp e do Grupo de Trabalho Texto Poético da Anpoll.

FÁBIO GABRIEL NASCIBEM - Aluno do Curso de Graduação em Química - IQ/Unesp. Bolsista de projetos de extensão.

FLÁVIA REGINA MARIA - Aluna do Programa de Pós-Graduação em Ciências Ambientais/UFSCar. Licenciada e Bacharel em Ciências Sociais pela FCLAr/Unesp. Bolsista de projetos de extensão.

FRANCISCO JOSÉ CARVALHO MAZZEU - Professor assistente doutor no Departamento de Didática da Faculdade de Ciências e Letras (FCL)- Unesp/câmpus Araraquara e pesquisador da Rede Unitrabalho. Coordena o Programa de Educação de Jovens e Adultos (PEJA), na FCL - Unesp/câmpus Araraquara.

GREICE KELLI CHRISTOVAM - Aluna do Programa de Pós-Graduação em Educação Escolar - Unesp. Graduada em Pedagogia pela FCLAr/Unesp.

JORGE HENRIQUE DE OLIVEIRA SILVA - Mestrando profissional em Gestão de Organizações e Sistemas Públicos pela UFSCar. Bacharel em Administração Pública pela FCLAr Unesp. Funcionário público federal.

JULIANA MARGATO RODRIGUES - Aluna do Curso de Graduação em Letras da FCLAr/Unesp. Bolsista de projetos de extensão.

LAÍS GOYOS PIERONI - Professora da Educação Básica. Colaboradora em projetos de extensão. 
LAÍS MARIN DE CAMPOS - Aluna do Curso de Graduação em Letras da FCLAr/Unesp. Bolsista de projetos de extensão.

LUCI REGINA MUZZETI - Professora da Faculdade de Ciências e Letras de Araraquara - Unesp. Coordenadora do Projeto de Extensão Ler É Viver.

MARIA CRISTINA DE SENZI ZANCUL - Professora da Faculdade de Ciências e Letras de Araraquara (FCLAr)/Unesp. Coordenadora do Projeto de Extensão Ciências e Ambiente: a Universidade em Diálogo com a Escola.

MARIA CRISTINA RECKZIEGEL GUEDES EVANGELISTA - Professora de língua alemã - Departamento de Letras Modernas - FCLAr.

MARIA FERNANDA CELLI DE OLIVEIRA - Aluna do Programa de Pós-Graduação em Educação Escolar - Unesp. Graduada em Pedagogia pela FCLAr/Unesp.

MONIELE ROCHA DE SOUZA - Professora da Educação Básica. Aluna do Programa de Pós-Graduação em Educação Escolar/ Unesp. Colaboradora em projetos de extensão.

NILDICÉIA APARECIDA ROCHA - Professora de língua espanhola - Departamento de Letras Modernas - FCLAr.

PATRICIA BORBA MARCHETTO - Docente do Departamento de Administração Pública da FCLAr/Unesp. Coordenadora do Projeto AdministrAÇÕES.

PEDRO NEVES DA ROCHA - Aluno do Programa de Pós-Graduação Multiunidades em Ensino de Ciências e Matemática/Unicamp. Colaborador nos projetos de extensão. 
RELMA UREL CARBONE CARNEIRO - Professora doutora do Departamento de Psicologia da Educação e do Programa de Pós-Graduação da Faculdade de Ciências e Letras de Araraquara/ Unesp.e-mail: relmaurel@ffclar.unesp.br.

ROSANGELA SANCHES DA SILVEIRA GILENO - Professora de Prática de Ensino e estágio supervisionado em língua materna e língua estrangeira (francês, espanhol e italiano) - Departamento de Didática - FCLAr.

SANDRA MARIA ARAÚJO DOURADO - Professora da Educação Básica. Aluna do Programa de Pós-Graduação em Educação Escolar/Unesp. Colaboradora em projetos de extensão.

SUZANA CRISTINA FERNANDES DE PAIVA - Professora do Departamento de Economia da Unesp/câmpus Araraquara, vice-coordenadora do Curso de Graduação de Ciências Econômicas, presidente do Comitê de Ética em Pesquisa da FCLAr e tutora do PET-Economia.

TALITA MAZZINI LOPES - Professora da Educação Básica. Aluna do Programa de Pós-Graduação em Educação Escolar/ Unesp. Colaboradora em projetos de extensão.

VIVIANE CRISTINA DA SILVA - Professora da Educação Básica. Colaboradora em projetos de extensão.

WAGNER DE MELO ROMÃO - Foi professor do Departamento de Antropologia, Política e Filosofia da Faculdade de Ciências e Letras da Unesp, câmpus Araraquara. Atualmente é professor do Departamento de Ciência Política da Unicamp e professor do Programa de Pós-Graduação em Ciências Sociais da Unesp-FCLAr. 


\author{
SOBRE O LIVRO \\ Formato: $14 \times 21 \mathrm{~cm}$ \\ Mancha: 23, $7 \times 40,10$ paicas \\ Tipologia: Horley Old Style 10,5/14 \\ 2016 \\ EQUIPE DE REALIZAÇÃO \\ Coordenação Geral \\ Pedro Barros (Tikinet Edição Ltda.)
}

